Andrews University

Digital Commons @ Andrews University

1995

\title{
An Intellectual Approach to the Communication of the Biblical Message to Secular People
}

Michele Buonfiglio

Follow this and additional works at: https://digitalcommons.andrews.edu/dmin

Part of the Practical Theology Commons

\section{Recommended Citation}

Buonfiglio, Michele, "An Intellectual Approach to the Communication of the Biblical Message to Secular People" (1995). Professional Dissertations DMin. 659.

https://dx.doi.org/10.32597/dmin/659

https://digitalcommons.andrews.edu/dmin/659

This Project Report is brought to you for free and open access by the Graduate Research at Digital Commons @ Andrews University. It has been accepted for inclusion in Professional Dissertations DMin by an authorized administrator of Digital Commons @ Andrews University. For more information, please contact repository@andrews.edu. 


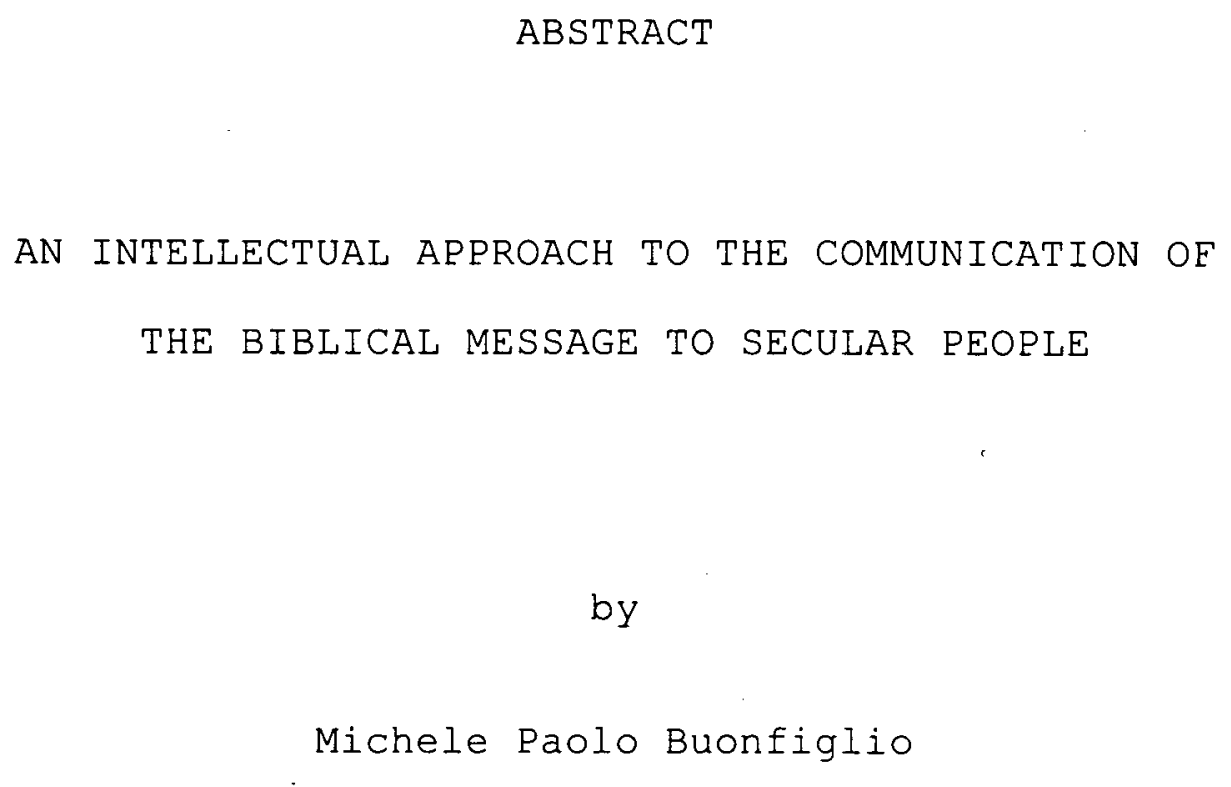

Adviser: Russell L. Staples 


\title{
ABSTRACT OF GRADUATE STUDENT RESEARCH
}

Dissertation

\author{
Andrews University \\ Seventh-day Adventist Theological Seminary
}

Title: AN INTELLECTUAL APPROACH TO THE COMMUNICATION OE THE BIBLICAL MESSAGE TO SECULAR PEOPLE

Name of the researcher: Michele Paolo Buonfiglio

Name and degree of faculty adviser: Russell L. Staples, $\mathrm{Ph}$. D.

Date completed: November 1996

One of the most important responsibilities given

Christians is to "make disciples from all nations." This includes secular people.

The communication of the biblical message to secular people is a complex and difficult assignment. The difficulty increases when secular people are intellectuals. Many currents of thought including philosophy and scientific understandings of reality have contributed to the formation of the Western secular mind. 
In Part one of the dissertation, philosophical, theological, and scientific theories that have contributed to the development of the process of secularization are considered. The section culminates with a profile of secular people.

The methods and strategy used by the Apostle Paul with intellectuals of his time provide an example to the presentday witness to secular people. In Part Two there is an analysis of Paul's methods and an application of these to the contemporary challenge of communicating the biblical message to secular people.

The process of communication of the biblical message involves three different cultures--the Hebrew culture of the biblical writers, the culture of Western secular people, and the Christian culture of the communicator. The process of communication is examined in order to avoid syncretism between the different cultures and/or irrelevance in the presentation of the biblical message.

The Christian message may be rejected because of a falsely conceived antinomy between certain biblical teachings and contemporary understandings of the way things are. Some such issues are examined and methods outlined of presenting essential elements of the biblical message.

The messengers must be prepared with care. Some practical recommendations are presented.

Secular intellectuals remain largely beyond the reach 
of present methods of evangelism. Christians concerned about the problems and challenges involved in the presentation of the biblical message to secular people can find useful suggestions for their work in this study. 


\author{
Andrews University \\ Seventh-day Adventist Theological Seminary
}

AN INTELLECTUAL APPROACH TO THE COMMUNICATION

OF THE BIBLICAL MESSAGE TO SECULAR PEOPLE

\author{
A Dissertation \\ Presented in Partial Fulfillment \\ of the Requirements for the Degree \\ Doctor of Ministry
}

by

Michele Paolo Buonfiglio

November 1996 

AN INTELLECTUAL APPROACH TO THE COMMUNICATION OF THE BIBLICAL MESSAGE TO SECULAR PEOPLE

A dissertation

presented in partial fulfillment

of the requirements for the degree

Doctor of Ministry

by

Michele Polo Buonfiglio

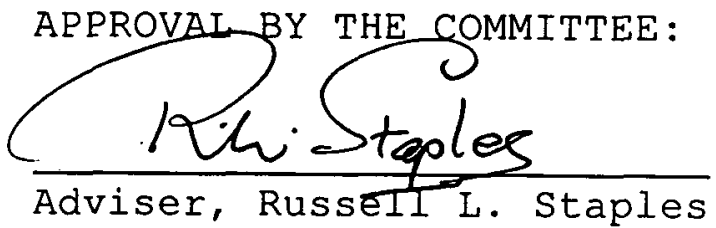

Bruce L. Bauer

Bruce L. Bauer

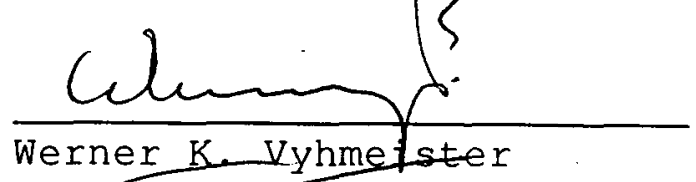

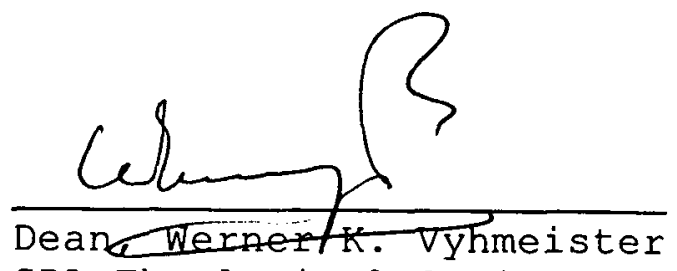

SDA Theological Seminary

December 12,1996

Date approved 
To my mother who nurtured me in the biblical faith, to my wife Melitta, and my sons who always stimulated me to study deeply God's Word 
ACKNOWLEDGMENTS . . . . . . . . . . . . . . . . . . viii

Chapter

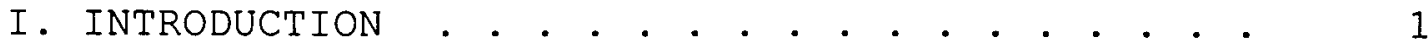

The Problem . . . . . . . . . . . . . . . . 1

Purpose of Dissertation . . . . . . . . . 3

Limitations . . . . . . . . . . . . . . 5

Methodology . . . . . . . . . . . . 6

PART ONE: THE PROCESS OF SECULARIZATION AND

THE PROFILE OF SECULAR PEOPLE

II. THE MEANING OF THE WORDS SECULAR, SECULARIZATION,

AND SECULARISM . . . . . . . . . . . . . . .

Introduction . . . . . . . . . . . . . . . 13

The Origin and Meaning of Word Secular . . 13

The Meaning of the Term Secularization . . 16

Secularism . . . . . . . . . . . . . 19

Summary . . . . . . . . . . . . . . . . . 21

III. THE PHILOSOPHICAL THEORIES THAT CONTRIBUTED TO THE FORMATION OE SECULAR INTELLECTUAL MAN • 22

Introduction . . . . . . . . . . . . . 22

Greek Concepts in Western Culture . . . . . 23

The Origin of Western and Pre-Socratic

Philosophy. . . . . . . . . . . 24

Dualistic Pythagorean Philosophy . . . . . 25

The First Form of Materialism. . . . . . . 25

The Relativism of Sophists . . . . . . . 26

The Ontological Dualism of Plato . . . . . 28

Aristotle, the Philosopher who

Influenced Western Scientific Thought . 30

Epicureanism and the First Form of Deism . 32

Skepticism . . . . . . . . . . . . . . . . 33

Renaissance and the Centrality of Human
Beings. . . . . . . . . . . . . . 34

The Birth of Secular Political Man . . . 36 
British Empiricism . . . . . . . . . . . 37

Enlightenment . . . . . . . . . . . . . . . 40

Deism . . . . . . . . . . . . . . . . . . . 41

Hegel and the Absolute Idealism . . . . . . 42

Pragmatism . . . . . . . . . . . . . . . 43

Existentialism . . . . . . . . . . . . 45

Heidegger . . . . . . . . . . . . . . . . . 46

Sartre: An Atheistic Existentialist. . . . 48

God Is Dead . . . . . . . . . . . . . . . . 49

Agnosticism of Bertrand Russell . . . . . . 51

The Postmodern Mind... . . . . . . . . . 54

The Gradual Fall of Human Certainties. . . 60

Summary . . . . . . . . . . . . . 62

IV. THE THEOLOGICAL THEORIES THAT CONTRIBUTED TO THE FORMATION OF SECULAR INTELLECTUAL MAN . . . . . . 64

Introduction . . . . . . . . . . . . . . . 64

Syncretism and the Origin of Medieval
Christianity . . . . . . . . . . . . . 65

The Middle Ages and Nominalism . . . . . . 69

The Reformation . . . . . . . . . . . . . . . 70

The Thirty Years' War and Emancipation of the

States from the Ties of Christianity . . 72

Liberal Protestant Theology and

Demythologization . . . . . . . . . . 74

Arguments against the Existence of God . . 76

Tillich Attempted to Mediate between Christian

Theology and Modern Culture . . . . . 79

Before God but Without God . . . . . . . . 81

The Secular Theology . . . . . . . . . . . . 84

Christian Theology: Vehicle of Dualism . . $\quad 89$

Summary . . . . . . . . . . . . . . . . 90

V. SCIENTIFIC THEORIES THAT CONTRIBUTED TO THE

FORMATION OF SECULAR INTELLECTUAL MAN . . . . . . 91

Introduction . . . . . . . . . . . . . . . 91

The Geocentric Universe . . . . . . . . . . . . . 99

The Heliocentric System of Copernicus . . . 93

Nature Written in Mathematical Language . . 94

A Mechanistic Model of the Universe. . . . 96

Scientific Discoveries and

the New Worldview . . . . . . . . . 97

Positivism . . . . . . . . . . . . . . . . . . 99

New Scientific Discoveries in Physics

and Natural Sciences... . . . . . . 101

Neo-positivism . . . . . . . . . . . . . . 103

Positive and Negative Effects Produced

by Technology............. . . 108

Some Final Considerations . . . . . . . . . 110 
VI. AN INTELLECTUAL PROFILE OF SECULAR PEOPLE . .

Introduction . . . . . . . . . . . . . . . 113

Secularism Is Inadequate for the Life of Human beings

The Philosophical Thought of Secular People. . . . . . . . . . . 117

The Ethical Relativism of Secular People . 119

The Religious Thought of Secular People . . 121

What secular People Think about Science and Technology . . . . . . . . . . . . . 128

Other Characteristics of Secular People, Power, Prestige, and Pleasure . . . . 129

The Human Search for Meaning . . . . . . . 132

Summary of Part One . . . . . . . . . . 134

\section{PART TWO: HOW TO COMMUNICATE AND PRESENT THE BIBLICAL MESSAGE}

VII. PAUL'S METHODS OF REACHING INTELLECTUAL PEOPLE.

Introduction . . . . . . . . . . . . . . 136

Paul: A Jew Born in Tarsus . . . . . . . . 136

Paul, the Apostle to Jews and Greeks . . . 138

Paul's Preaching to Intellectual People of His Time

139

The Areopagus Speech . . . . . . . . . . . 142

Other Characteristics of Paul!s Message. . 147

Some Final Considerations . . . . . . . . . 148

VIII. THE PROCESS OF COMMUNICATION: LANGUAGES, CULTURE, AND THE BIBLICAL MESSAGE . . . . . . . 150

Introduction . . . . . . . . . . . . . . 150

The Process of Communication . . . . . . 152

Languages and the Biblical Message . . . 158

Defining Culture . . . . . . . . . . . 162

Enculturation and Acculturation . . . . . . 163

Contextualization. . . . . . . . . . . 164

Critical Contextualization: An Approach
Suggested by the Anthropologist Hiebert. 167

Contextualized Theology . . . . . . . . . 174

Summary . . . . . . . . . . . . . . . 177

IX. THE BIBLICAL MESSAGE: HOW TO PRESENT GOD TO SECULAR PEOPLE . . . . . . . . . . . . . . . . . . 179

Introduction . . . . . . . . . . . . . . . 179

Religion: An Encounter with God . . . . . . 181 
Helping Secular People to Recover

a Sense of the Divine . . . . . . . . . 186

God, the Covenant, and God's People. . . . 186

Yahweh Is One . . . . . . . . . . . . . . . 188

Yahweh, the Creator . . . . . . . . . . 191

Two Different Conservative Interpretations of Gen 1 . . . . . . . . . . . . . . . . 192

An Exegesis of the Biblical Story of Creation . . . . . . . . . . . . . . 195

The Biblical Story of Creation and Its Basic Philosophical Thought . . . 203

The Biblical story of Creation and
Science . . . . . . . . . . . . . . 204

God Has Spoken . . . . . . . . . . . . . 208

God Acts in Human History. . . . . . . . . 214

God Is Love. . . . . . . . . . . . . . . 216

Summary . . . . . . . . . . . . . . . . 220

X. HOW TO PRESENT THE COVENANT TO SECULAR PEOPLE . 221

Introduction . . . . . . . . . . . . . 221

The Covenant . . . . . . . . . . . . 222

Some Final Considerations . . . . . . . 236

XI. THE CHURCH AS THE PEOPLE OF GOD . . . . . . . . . 238

Introduction . . . . . . . . . . . . 238

The Church as People of God . . . . . . 238

The Ministry . . . . . . . . . . . . . 240

The Biblical View of Holistic Ministry . . 243

The Biblical Message for

Some Practical Recommendations. . . . . . 249

Summary . . . . . . . . . . . . . 253

XII. CONCLUSION . . . . . . . . . . . . . . . . 254

Conclusion . . . . . . . . . . . . 254

APPENDIX: ELLEN G. WhITE STATEMENTS . . . . . . . . 257

SELECTED BIBLIOGRAPHY . . . . . . . . . . . . . . . . 259 


\section{ACKNOWLEDGMENTS}

I wish to thank Dr. Russell L. Staples and Dr. Bruce L. Bauer for their careful reading of my dissertation and for their helpful suggestions. I am also most grateful to Mrs. Bonnie Proctor and Mrs. Irma Lidner who made editorial suggestions for my dissertation.

Above all, I am grateful to God for His help, without which it would have been impossible in so little time to elaborate and write this dissertation in a language that is not mine.

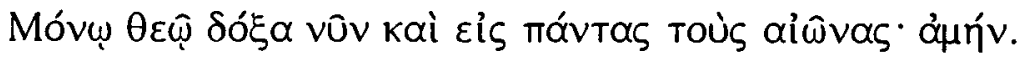


CHAPTER I

\section{INTRODUCTION}

\section{The Problem}

We live in a time in which scientific and technological development has deeply changed our way of living. Our houses, schools, hospitals, offices, and streets are full of machines. We sleep, eat, write, communicate, travel, and take care of ourselves using every kind of apparatus. Science and technology qualify our daily lives. Their tangible achievements have increased the confidence of people in them, thus influencing their ways of thinking, feeling, and acting. People believe that science and technology have the capacity to solve almost all human problems and are generally inclined to overestimate their results.

It is a strange matter of fact that those who watch and admire scientific research from the outside frequently have more confidence in its results than the men who cooperate in its progress. The scientist. . realizes that discrepancies and new difficulties may arise at any moment, and he will never claim to have found the ultimate truth. . . The overestimation of the reliability of scientific results. . . has become a general feature of modern times. . . The belief that science has the answer to all questions 
- . is so widespread that science has taken over a social function which originally was satisfied by religion. Even where religion was regarded as compatible with science, it was modified by the mentality of the believer in scientific truth. ${ }^{1}$

Science has not eliminated religion, but it has made it irrelevant to many. Religion is playing a reduced role in family life, in education, in economic and social affairs. Many people are convinced that the age of religion is past. Science and technology dominate the minds of contemporary people and have contributed to the development of the process of secularization.

In this dissertation, secularization is regarded as the process of gradual displacement of religious interpretations of physical reality and human life by a nonreligious orientation that seeks explanations for physical phenomena and justifications of human behavior in scientific terms. The world is desacralized; religious considerations are excluded from public education and from many affairs, which are regarded as civil. People are seeking explanations of phenomena such as death, life, sickness, healing, war, peace, etc., in the physical, psychological, and social sciences.

Secularization prepares the way for secularism, which

${ }^{1}$ Hans Reichenbach, The Rise of Scientific Philosophy (Berkeley and Los Angeles: University of California Press, 1959), 43, 44 . 
is a philosophical attitude that is oriented to the profane rather than the sacred and which leads to the rejection of supernatural values. ${ }^{1}$

Secular people, i.e., individuals of Western society influenced by the process of secularization, may not deny the existence of God, but they are generally inclined to think that the human being has no need of God, and many feel no need for organized religion. Attitudes toward the church range from indifference to antagonism.

A major challenge facing Christianity is how to present the biblical message to secular people. Since many have a marked resistance toward anything that comes from a religious institution, secular people have great difficulty in receiving the biblical message. Therefore the crucial problem examined by this dissertation is how to present the biblical message to secular people in a way that attracts them, so that they will receive and live by it.

\section{Purpose of Dissertation}

After His resurrection, Jesus commissioned His

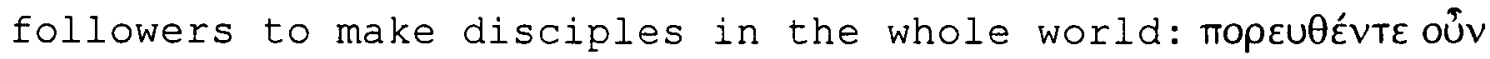

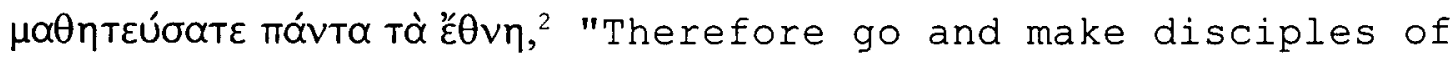

${ }^{1}$ See p. 20 below.

${ }^{2}$ The Greek New Testament quoted is the Nestle-Aland 26th Edition. 
all nations"1 (Matt 28:19). In the book of Revelation we

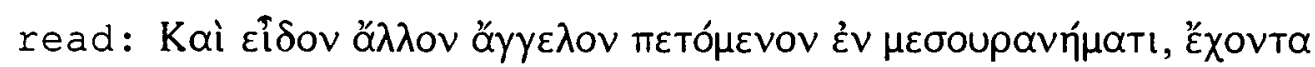

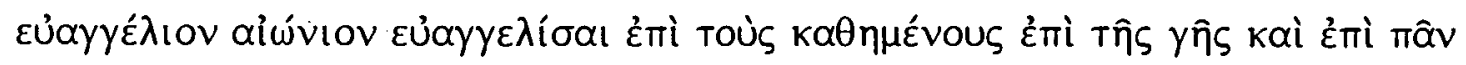

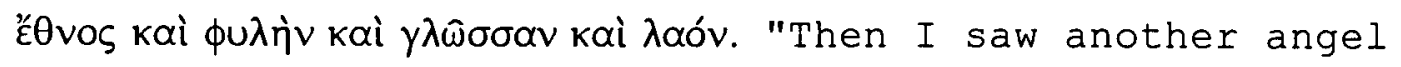
flying in midair, and he had the eternal gospel to proclaim to those who live on the earth--to every nation, tribe, language and people" (Rev 14:6). The two statements include all ethnic and cultural groups.

It is the task of true disciples of Christ to present

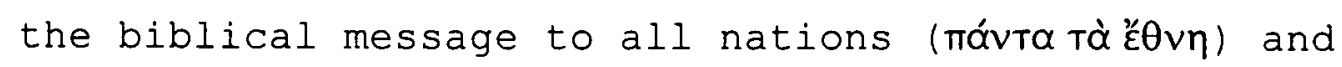
cultural groups ( Jesus asks His disciples to present the biblical message to all, including secular people. Jesus wants every person to listen to and understand the biblical message. If biblical communicators want to make this message relevant and comprehensible to their listeners, they should seriously examine their approach to people. They must learn how to present the message in a way that can be understood by every group. Obviously, the message remains the same, but the presentation needs to be adapted to the background of the hearers.

It is necessary to realize the problems encountered in

${ }^{1}$ The English version of Scriptures quoted is the New International Version. 
the presentation of the biblical message to secular people. They have a specific culture, a particular worldview, and their own way of thinking, feeling, and acting. The disciples of Jesus need to learn how they can approach this kind of person.

The purpose of this investigation is to: (1) describe the rise and development of the process of secularization; (2) construct a profile of secular people; (3) explore the barriers to the communication of the biblical message to secular people and the possible avenues of approach in presenting it; (4) develop a strategy that allows biblical communicators to engage this cultural group that remains largely beyond the reach of present methods of evangelism.

There are many professionals, such as physicians, lawyers, professors, and politicians among secular people, who, once converted to God, could help powerfully in bringing the biblical message to their friends.

\section{Limitations}

The title of this dissertation is "An Intellectual Approach to the Communication of the Biblical Message to Secular People." This investigation is thus focused on a special group of people.

The purpose is to find the most efficient and effective intellectual approach to communicate the Gospel to secular 
people. However, the emotional and spiritual aspects of the approach are not completely excluded.

Some recommendations regarding practical means of reaching secular people are also given in the last part of the dissertation.

\section{Methodology}

If a physician wants to heal a patient, he needs to do two things: diagnose the sickness and prescribe a therapy. He must know the symptoms, so that he can differentiate the specific illness from other similar ones and identify it. Then he prescribes the medicine and/or actions adequate to heal the patient.

The same approach is followed in this dissertation. The diagnosis is elaborated in Part one and the therapy in Part Two. The study culminates in some practical recommendations and suggestions.

As we have seen, ${ }^{1}$ the purpose of this dissertation in a broad meaning is the study of the process of secularization, of the methods to reach secular people, and of the best manner to present the biblical message to them. An interdisciplinary approach is pursued in order to achieve these objectives. Secularization is a social phenomenon.

\footnotetext{
${ }^{1}$ See p. 5 above.
} 
Therefore, sociological interpretations of this process are employed.

In Part One, chapters 3,4 , and 5 are dedicated to a study of the history of the process of secularization in Western society. Special consideration has been given to the thinkers who have played an important part in the development of secularism.

Selected literature is reviewed in order to provide an understanding of the historical process of secularization. Sometimes it has been sufficient to examine works of history of philosophy published by known historians; often it has been necessary to consult directly the works of philosophers, scientists, or theologians to understand their thought better, e.g., how the Renaissance, Enlightenment, modern science, nineteenth-century critiques against the existence of God, the agnosticism of some scientists, existentialism, secular theology, and political and sociological theories have contributed to the rise of secularism.

The description of the thought of seminal thinkers who have contributed to the formation of the process of secularization helps to elucidate the attitudes and characteristics of secular people. This description of the process of secularization and of the profile of secular 
people helps to make it possible for the biblical communicator to recognize indicators that help to identify the sickness. In chapter 6 a profile of secular people is outlined.

In Part Two, the therapy begins. Chapter 7 is dedicated to an analysis of the methods and strategy used by the Apostle Paul that helps us point to some principles. Selected biographies and studies about the thought and methods of Paul are reviewed.

Human beings are influenced by their own culture. The communicator and the receptor each have their own. Often communicators present a mixture of the biblical message and their own culture. People who receive the biblical message tend to adapt God's word to their own needs and aspirations, rather than allowing the Bible to transform their ways of thinking, feeling, and living.

For many at that time, Christianity and modern civilization went together. After the experiences of the past seventy-five years that is no longer so. There is a profound collapse of belief in the future of our civilization. . . . If our own culture has proved bankrupt, and if all expressions of the gospel are culturally embodied, it is understandable that a collapse of confidence in our culture goes along with a faltering of confidence in the gospel. ${ }^{1}$

Then, Newbigin asks: "If the gospel is always and

${ }^{1}$ Lesslie Newbigin, The Gospel in a Pluralistic Society (Grand Rapids, MI: William B. Eerdmans Publishing Company, 1989), 191 . 
everywhere culturally embodied, . . how can it be possible for the gospel to have a critical relation to culture?"1

Some believe that is impossible.

A recent writer in Theology, reviewing my book

Foolishness to the Greeks, says bluntly that it is impossible. Trying to criticize one's own culture is, he says, like pretending to move a bus when you are sitting in it. We are what our culture has made us and we have to accept that fact. To appeal to the Bible is futile. ${ }^{2}$

Rightly, Newbigin observes:

During the 1914-1918 war the churches on both sides made an almost total identification of the cause of Christ with the cause of their own nation. . . It was a scandal of that situation which shocked many. . . and caused them to realize that European Christianity was guilty of a fatal syncretism, and send them back to a fresh and more humble listening to the Bible. . . In the Second World War the blasphemies of the First were not repeated. . . Almost as soon as the war was over the church leaders on the two sides were meeting together to work and pray for a new form of Christian presence in Europe. ${ }^{3}$

In order to understand what happens and what must

happen when the biblical message is presented to secular people, it is necessary to understand how God transforms the culture of everyone who receives the biblical message and establishes a relationship with Him.

Anthropology, the science that studies human beings,

${ }^{1}$ Ibid.

${ }^{2}$ Ibid.

${ }^{3}$ Ibid., 196. 
helps to define human culture, the relationship between culture and human languages, and the processes through which culture is transmitted. In addition, anthropological analysis can provide insights regarding the processes of communication.

The problems and difficulties that one finds when one is seeking to communicate the biblical message to secular people must be considered. It is necessary, even if briefly, to examine the process through which the message is presented. Chapter 8 is dedicated to examining the process of communication and the encounter between secular culture and the biblical message.

Sometimes the biblical message is presented to secular people in a superficial, abstract, or antiquated manner. The most important part of this investigation is dedicated to examining the biblical message and considering how it can be presented in a relevant, understandable way. The correct knowledge and presentation of the most important elements of the biblical message help to develop a better strategy to present it to secular people.

However, not all aspects of the biblical message are considered, only those that are more important and difficult to present to secular people. An attempt is made to present the message in such a way that intellectual secular people 
can understand and accept it.

Chapters 9, 10, and 11 are dedicated to the study of the biblical message. In particular, since science has greatly contributed to the development of the secular mind, special consideration is given to the problems of the relationship between science and the Bible.

A conclusion and some practical recommendations are given in chapter 12 . 
PART ONE

THE PROCESS OF SECULARIZATION AND

THE PROFILE OF SECULAR PEOPLE 
CHAPTER II

THE MEANING OF THE WORDS SECULAR, SECULARIZATION, AND SECULARISM

\section{Introduction}

The subject of this dissertation is the communication of the biblical message to secular people. In order to identify such people it is necessary to understand the meaning of the terms secular, secularization, and secularism. These terms are analyzed within the sections into which the chapter is divided.

\section{The Origin and the Meaning of the word Secular}

The word secular has its root in the Latin word saeculum, meaning period of time, age. In the Vulgate, the Latin version of the Bible of st. Jerome, the term saeculum translates two Greek words alẃv, age and kóouos, world. The word saeculum with the adjective this (oútos, hic) ${ }^{1}$ means

${ }^{1}$ Sometimes words and biblical verses are written in three or two languages following this order: Hebrew, Greek and Latin. For example the word covenant is written in Hebrew, Greek and Latin : דִּר, Latin word is underlined. 
this age, this world, our present time.

There are many examples of this usage in the Vulgate. For instance, in the Gospel of Luke, of vioí toũ $\alpha i \bar{\omega} v o s$ Toútou is translated filii saeculi huius, the people of this age (Luke 20:34); in the epistles of Paul to the Romans and

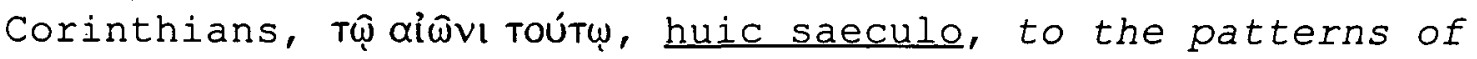
this world (Rom 12:2); toũ aī̄vos toútou, huius saeculi, of

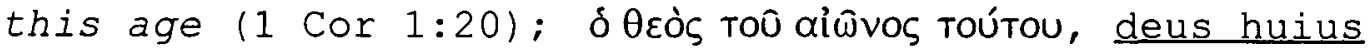
saeculi, the god of this age (2 Cor 4:4).

In Latin the word saeculum had a neutral meaning, neither negative nor positive; in the vulgate it also assumes a neutral sense. For example, in 1 Tim 1:17, saeculum means a great length of time, a long age: Tụ̂ $\delta \dot{\varepsilon}$

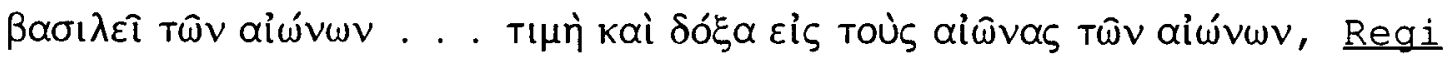
autem saeculorum.. honor et gloria in saecula saeculorum, to the King eternal. . . honor and glory forever and ever.

Nevertheless, with the adjective this (oưtos, hic), it is used with a negative religious meaning, because it refers to our present age that is dominated by evil. It is so used in Rom 12:2 and 2 Cor 4:4. Secular is used to describe a person who is bound to the present age and given to worldly

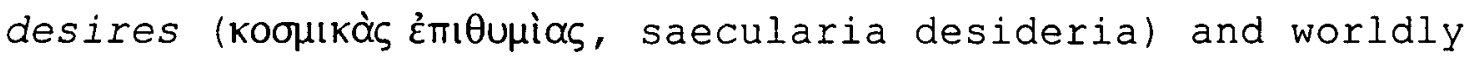
passions (Titus 2:12). 
Greeks conceived the world in terms of space, while Hebrews in terms of time. In the Middle Ages the Greek spatial conception of reality surpassed the Hebrew temporal conception and "secular" indicated the lower world, while religious the higher. H. Cox wrote:

The Greeks perceived existence spatially; the Hebrews perceived it temporally. . . . The medieval synthesis resolved the tension between Greek and Hebrew by making the spatial world the higher or religious one and the changing world of history the lower or "secular" one."

In the Middle Ages the word saeculum meant the profane world, as opposed to the world of religious men and women-the world of monks, nuns, and clergymen. The word secularization had a narrow meaning and designated the process by which a religious priest was transferred to a parish responsibility. Even today, in Catholic usage we find the expression secular clergy, which means that monastic vows do not bind them and they may possess secular property.

When the separation of Pope and Emperor became a fact, the distinction between religious/spiritual and secular/ material realms was institutionalized. Secularization designated the passing of certain responsibilities from ecclesiastical to political authorities.

\footnotetext{
${ }^{1}$ Harvey Cox, The Secular City (New York: Macmillan Company, 1966), 16-17.
} 
This practice continued throughout the periods of the Enlightenment and the Erench Revolution. Also in our time when the state appropriates ecclesiastical properties in countries with a Catholic cultural heritage, the secularization of Church properties takes place. For instance, when a school or hospital passes from ecclesiastical to public administration, the procedure is called secularization.

More recently, secularization also describes a cultural process that has entailed the removal of many sectors of human life and thought from the control of religion.

In contemporary usage, the term secular has come to mean profane, worldly, nonreligious--that is, the contrary of sacred, celestial, religious.

\section{The Meaning of the Term Secularization}

The process of secularization can be considered under two fundamental aspects: one political, the other intellectual.

Political secularization is the process through which a separation between the state and religion occurs.

In some periods of history it is possible to observe a close relation between religion and the state, which support each other. The state is the secular arm of the official 
religion and fortifies its position by laws and penalties, while religion supports the state, preserving stability. In these cases the religion is often controlled by the state.

Through the process of political secularization, religion becomes privatized, excluded from state institutions, such as education, social welfare, hospitals, etc., and confined to a particular group of people who choose it on a voluntary basis. Political secularization has given rise to religious pluralism and freedom.

Intellectual secularization is a process through which philosophers, scientists, sociologists, and politicians have relegated religion to a "private sphere." Philosophers have sought an explanation of the universe according to "natural" principles, and cast doubt on religious assertions. This process has primarily concerned elite groups, such as philosophers, scientists, artists, and writers.

Generally, today, the term secularization describes the historical movement of privatization of religion, in which the private sphere of life, the sphere of values and consequently of religion, is compartmentalized and separated from the public sphere, the sphere of facts and consequently of science.

According to Newbigin, a characteristic of Western 
society is "the separation between fact and value"1 which entails another division, "the division between the private world and public."2 The public world is the world of facts, "upon which every intelligent person is expected to agree;"3 the private world is a world of values, "where we are free to follow our own preference regarding personal conduct and lifestyle." 4

This fissure becomes visible in two ways: in the dichotomy (one of the outstanding marks of a "modern" society) between the public and the private worlds, and in the dichotomy in thought between what are commonly called "facts" and what are called "values." The public world is a world of facts that are the same for everyone, whatever his values may be; the private world is a world of values where all are free to choose their own values and therefore to pursue such courses of action as will correspond with them. At the intellectual level, this fissure expresses itself on the search for "value-free" facts, and for a science of human behavior that shall be "objective" in the sense that no value judgements are allowed to have a place in its operations. ${ }^{5}$

The term secularization, as it is used in this dissertation, signifies the gradual displacement of religious interpretations of the origin and meaning of

${ }^{1}$ Lesslie Newbigin, Foolishness to the Greeks (Grand Rapids, MI: William Eerdmans Publishing Company, 1986), 18.

${ }^{2}$ Ibid.

${ }^{3}$ Ibid., 19.

${ }^{4}$ Ibid.

${ }^{5}$ Ibid., 35, 36 . 
physical reality and human life by nonreligious naturalistic explanations with the result that physical phenomena and human behavior are largely accounted for in scientific terms. ${ }^{1}$ The process of secularization has not only influenced patterns of thought in the religious sphere, it has broadly shaped the cultural and traditional norms and perceptions of contemporary Western society.

\section{$\underline{\text { Secularism }}$}

There is confusion in the use of the terms secularism and secularization.

Confusion often persists in the use of the terms secularism and secularization. The latter is a neutral concept relating to broad processes occurring within society, while secularism is an ideology advocating the elimination of religious influence in the state and social institutions, particularly in education. The early secularists were essentially an anti-clerical party, but more generally secularism came to imply opposition to all religion, and a demand that secular criteria should determine social policy and education. ${ }^{2}$

For some scholars the process of secularization has replaced the concept of divine providence with the idea of human progress.

For others, this process has created the conditions for the independence of human culture in the face of religion

${ }^{1}$ See p. 2 above.

${ }^{2}$ Alan Richardson and John Bowden, eds., $\underline{\text { A New }}$ Dictionary of Christian Theology (London: SCM Press, 1989), 533. 
and consequently a loss of the centrality of God in human life and a rebellion against the God of Christianity.

Briefly, it should be recognized that the process of secularization has helped to eliminate some inappropriate ways in which God and religious faith have been conceptualized and has created conditions favorable to religious liberty.

However, the process of secularization has also created the conditions for the formation of secularism, which excludes religious values from human life. For biblical Christian theology, secularism is guilty because it has excluded God from human affairs.

From the perspective of biblical Christian theology, secularism is guilty for having "exchanged the truth of God for a lie, and worshiped and served the creature rather than the Creator" (Rom 1:25). Having excluded the transcendent God as the absolute and the object of worship, the secularist inexorably makes the world of man and nature absolute and object of worship. ${ }^{1}$

In short, the term secularization is used to describe the processes in which many sectors of culture and society passed from religious to nonreligious or civil control, while secularism is a "way of life and thought that is pursued without reference to God and religion."2

${ }^{1}$ Walter A. Elwell, Evangelical Dictionary of Theology (Grand Rapids, MI: Baker Book House, 1984), 997.

${ }^{2}$ Ibid., 996. 
Summary

In this chapter we have considered the meaning of the words secular, secularization, and secularism. In chapters $3,4,5$ the historical development of the process of secularization is examined.

The examination of this historical process will help us to outline the profile of secular people, which is considered in chapter 6. 
CHAPTER III

THE PHILOSOPHICAL THEORIES THAT CONTRIBUTED TO THE FORMATION OF SECULAR INTELLECTUAL MAN

\section{Introduction}

From Greek-Roman times until the present day philosophical, scientific, and theological thought have contributed to the formation of cognitive man, the secular intellectual man.

Many of the ideas that formed the Western secular mind derive from very old philosophical systems. It is important to understand from which systems the secular mind originated and the historical process through which it developed for three fundamental reasons:

1. It shows us how old and rooted in the Western mind is the Greek-Roman philosophical vision of reality.

2. It helps us to understand how difficult it is to eradicate this vision.

3. It indicates how profoundly, and often unconsciously, the Western mind is influenced by Greek philosophy. 
Paul Eidelberg points to the deep relation existing between Western culture and Greek philosophy.

With Greek philosophy a new type of man appeared in the forefront of world history, Cognitive Man. Cognitive Man is a secularist who deifies the intellect. ${ }^{1}$

For Western people, it is very difficult to realize how much their culture, their knowledge, values, worldview, etc., are formed within a Greek-Roman tradition.

Western communicators of the biblical message are so persuasively influenced by their culture that in the "presentation of the gospel they have often confused culturally conditioned perceptions with the substance of the gospel, and thus wrongfully claimed divine authority for the relativities of one culture." ${ }^{2}$

In chapter 3 the philosophical trends, which contributed to the formation of the Western secular mind, are considered; in chapter 4, the theological thought; and in chapter 5 , the scientific theories.

\section{Greek Concepts in Western Culture}

Over the course of a millennium Greek-Roman philosophy developed what today constitutes the cultural foundations of Western thought. Western thinkers received a series of

${ }^{1}$ Paul Eidelberg, Beyond the Secular Mind (New York: Greenwood Press, 1989), 4.

${ }^{2}$ Lesslie Newbigin, Eoolishness of the Greeks, 2. 
concepts, such as principle, element, matter, spirit, time, eternity, etc., from Greek-Roman philosophy.

Medieval theology, classical humanism, and modern science all are deeply in debt to Greek and Roman thinkers, who created a new series of intellectual concepts that still today are a fundamental part of Western thought. This fact is worthy of admiration but also creates some apprehensions. It is right to inquire if this old language, rooted deeply in Western thinkers' minds, can suggest false concepts that hinder Western people from understanding and accepting the biblical message.

\section{The Origin of Western and Pre-Socratic Philosophy}

Western philosophy rose with the observations and reflections of the first Greek philosophers in the sixth century B.C., who were called pre-Socratic.

The beginning of Greek thought was characterized by the research of the principle upon which to build conceptions of the world and human beings. According to pre-Socratic philosophers, the principle of all things was a physical element, such as water, air, fire, atoms, etc.

With pre-Socratic philosophers the desacralization of nature began. They divested of sacred significance the cosmos and man, which religious systems of Egypt and Babylon 
considered sacred.

The process of desacralization of nature began with the Greek philosophers who, in the sixth and fifth centuries B.C., began to separate religious thought from the philosophical and scientific. They were the first human beings to seek for rational explanations of natural phenomena.

\section{Dualistic Pythagorean Philosophy}

Pythagoras (570-497 B.C.) regarded mathematics as the supreme form of knowledge. Pythagoreans focused on the mathematical forms that governed and ordered the phenomena. They discovered that musical harmonies could be correlated with mathematical ratios.

The Pythagorean mathematical vision of a physical world with its dichotomies (body/soul, matter/spirit, limit/unlimited, one/many, etc.) influenced Plato's thought and continued to orient Western thought.

\section{The First Form of Materialism}

In order to explain the apparent contradiction between the single, eternal, absolutely compact being of Parmenides and the becoming, perpetual flux of Heraclitus the Greek philosopher, Leucippus (the date of his birth is unknown) and Democritus (circa 460 B.C.) postulated a new concept 
expressed by the word atom, which means indivisible.

They developed an atomic theory of the universe according to which all things are composed of minute, invisible, indestructible particles of pure matter, which move about eternally in infinite empty space (the void). The atomists excluded all mythological residues from their philosophical thought. Atoms were moved mechanically by the blind change of natural necessity and not by any cosmic intelligence, such as Logos or Nous. The void alone caused the random motions of the atoms, which were entirely material and possessed neither divine order nor purpose. Human knowledge was derived simply from the impact of the material atoms on the senses.

According to the atomists, the origin of worlds is the natural consequence of the ceaseless whirling motion of atoms in space. Atoms collide and spin, forming larger aggregations of matter. With atomists is found a cosmogony, in which there was no intervention of any deity.

\section{The Relativism of the Sophists}

Athens reached the climax of its intellectual development in the fifth century B.C. In that time, philosophical and different literary and artistic trends converged.

In the course of the fifth century, Hellenic culture 
attained a delicate and fertile balance between the ancient mythological tradition and the modern secular rationalism. . . . The Temples to Zeus, Athena, and Apollo seemed to celebrate man's triumph of rational clarity and mathematical elegance as much as they offered homage to the divine. . . . The most acute stage in this evolution was reached in the latter half of the fifth century with the emergence of the sophists - . itinerant professional teachers, secular humanists of a liberal spirit. ${ }^{1}$

According to the Sophists--Gorgias (483-375) and

Protagoras (481-411)--the truth does not depend on the observed object, but on the subject who observes. Truth is relative to the subject who observes it; therefore, completely subjective. What appears true or false to anyone is so, as far as he is concerned. But human beings change; so what appears true today may appear false tomorrow. According to Aristotle, "Gorgias declares that nothing exists; and if anything exists it is unknowable; and if it exists and is knowable, yet it cannot be indicated to others." 2

The human being of whom Sophists spoke was an individual who changes in time and space.

Protagoras exulted in teaching youth that "man is the measure of all things." This unheard of and skeptical doctrine--the dogma of today's universities--signifies

${ }^{1}$ Richard Tarnas, The Passion of the Western Mind (New York: Ballantine Books, 1993), 25, 26.

${ }^{2}$ Aristotle, The Complete Works of Aristotle, ed. Jonathan Barnes (Princeton, NJ: Princeton University Press, $1984), 2: 1548$. 
that all ideas concerning the True, the Good, and the Beautiful are human creations, hence relative to time and place. Socrates saw that this secularism cum relativism. . . would eventually destroy the Olympian gods and was even then undermining public morality in Athens, the "open society" of the Hellenic Age."

According to Sophists, the existence of gods could not be demonstrated. They concluded in favor of flexible atheism or agnosticism in metaphysics. Religious beliefs, political structures, and moral rules were all conventions created by humans.

\section{The Ontological Dualism of Plato}

One of the most influential thinkers in Western philosophy was the Greek philosopher Plato (427-347 B.C.). His dualistic vision of reality clearly influenced Western thinking.

$$
\begin{aligned}
& \text { Primary responsibility for the dualism of mind and } \\
& \text { nature in modern thought should be attributed to the } \\
& \text { Greek, and especially Platonic, dualism of reason and } \\
& \text { matter. } \\
& \text { Plato incorporated in his philosophy many insights of }
\end{aligned}
$$

the Pre-Socratic philosophers. He took from Parmenides the changeless nature of intelligible reality; from Heraclitus the continuous flux of a sensible world; and above all from the Pythagoreans the intelligibility of reality via

${ }^{1}$ Eidelberg, Beyond the Secular Mind, 3.

${ }^{2}$ Wolfhart Pannenberg, Theology and the Philosophy of Science (Philadelphia: Westmister Press, 1976), 127. 
mathematical forms.

Pythagoreans had a mathematical vision of the universe whereas Plato had a geometrical one. In his book Timaeus, Plato suggested that the five elements (four terrestrial and one celestial) could have the form of five regular solids. Plato's philosophy tended to reinforce a Pythagorean orientation.

Indeed, the Pythagorean orientation became influential in the Christian West largely as a result of a marriage of Plato's Timaeus and Holy Scripture. In the Timaeus, Plato described the creation of the universe by a benevolent Demiurge, who impressed a mathematical pattern upon a formless primordial matter. . . For those who accepted this synthesis, the task of the natural philosopher is to uncover the mathematical pattern upon which the universe is ordered. ${ }^{1}$

According to Plato, it is possible to reach certain and infallible knowledge only by discovering the reality that is beyond the phenomena, which are imperfect and transitory. Beyond them exist the eternal, absolute, and ideal forms. Plato conceived the forms as arranged hierarchically; the supreme Form is the Form of the Good.

Plato's dualism has influenced Western philosophy through all its history.

A basic shift took place when the gospel was translated into the . . world view of the Greeks. . . This Greek dualism [the dualism between spirit and matter,

John Losee, A Historical Introduction to the Philosophy of Science (London: Oxford University Press, $1972), 18,19$. 
soul and body] has dominated Western thought. . . and has led to a sharp distinction between science and religion. . . Many Westerners today use science to explain the natural world and limit religion to miracles and visions. ${ }^{1}$

This dualistic vision of reality has led Western people to make a distinction between material and spiritual

problems, natural and supernatural realms, profane and religious affairs, public and private spheres, etc. People accept science that, according to them, is based on reality but reject religion, which is considered as mere poetry, and is based on feeling and not on logical, rational, and analytic thought. ${ }^{2}$ The result is "a spread of secularism."3

\section{Aristotle: The Philosopher who Influenced Western Scientific Thought}

Aristotle (384-322 B.C.), Greek philosopher and scientist, strongly influenced many thinkers in the Middle Ages, and his influence still remains. He provided a language and logic, which permitted the development of Western philosophy, theology, and science.

Aristotle proposed a particular method for science. His method included two stages: inductive and deductive.

${ }^{1}$ Paul G. Hiebert, Anthropological Insights for Missionaries (Grand Rapids, MI: Baker Book 1985), 113, 114 .

${ }^{2}$ See pp. 89-90, 124-125 below. 114 .

${ }^{3}$ Hiebert, Anthropological Insights for Missionaries, 
The type of induction suggested by him was a simple enumeration. The premises and conclusions contained the same descriptive terms:
al has property $P$
a2 has property $P$
a3 has property $P$

: All a's have property P.

In the second stage, the generalizations reached by induction are premises from which it is possible to deduce statements that can be applied to the phenomena examined by scientists. In this stage, Aristotle used a form of deductive reasoning consisting of a major and a minor premise, and a conclusion, i.e., the syllogism.

There are various forms of syllogisms, but according to Aristotle, the more appropriate syllogism for the scientific method was that of type $A$, which can be exemplified in this way:

All $M$ are $P$
All S are $M$
- All S are $P$

The middle term (M) joins the subject (S) and the predicate (P) in the conclusion. His scientific method influenced scientific investigation throughout many centuries. The thought of Aristotle has even helped to shape modern language and thought.

The task of Socrates, completed by Plato and Aristotle, 
was. . to construct a philosophy of man and the universe that would replace the no longer credible mythology of the Homeric world. . . No longer were the gods to rule mankind, but reason--unaided human reason--would henceforth determine how man should live. - . The magnitude of Aristotle's program has not been surpassed in the history of philosophy. He merely set out to comprehend the totality of existence, to reduce heaven and earth and all between to an organized system of theoretical, practical, and productive sciences. - . With Greek philosophy a new type of man appeared - . Cognitive Man. Cognitive Man is a secularist who deifies the intellect. ${ }^{1}$

With Socrates, Plato, and Aristotle, Greek philosophy created a new type of human being: the secular intellectual human being.

\section{Epicureanism and the First Form of Deism}

Epicureanism is the system of philosophy based chiefly on the teachings of the Greek philosopher Epicurus (314-270 B.C.). Epicurus accepted the physic of the Greek atomists. According to him the universe is infinite, eternal, and formed of bodies and space. The world was produced by the whirls, collisions, and aggregations of the atoms.

Epicurus did not deny the existence of gods, but according to him, they dwell in wonderful residences and enjoy eternal, total happiness. Prayers, worship, and sacrifices are useless.

Humans must fear neither gods, because they do not take

${ }^{1}$ Eidelberg, Beyond the Secular Mind, 4. 
care of human life, destiny, which does not exist, nor death, in which both soul and body disintegrate in such a way that with death all problems and sorrows are eliminated. True happiness is the serenity that results from eliminating the fear of the gods, death, and the afterlife. The most important aim of Epicureanism is freeing people from such fears.

Epicureanism has attracted eminent persons in all ages, and presently many Western people seek serenity by eliminating fears and sorrows from their lives and believing that God exists but does not concern Himself with humans.

\section{Skepticism}

Skepticism is almost the natural result of the philosophical process. When human beings realize that their dogmatic beliefs have no solid foundation, they easily pass from blind dogmatism to a radical skepticism.

The many solutions proposed by different thinkers to the same problems result in mistrust of the rehability of human knowledge.

According to Pyrrho (third century B.C.), human beings can reach ataraxia, tranquillity of mind, by suspending all affirmations and abstaining from dogmatizing and the formulation of any kind of judgment.

There is no criterion for establishing truth, because 
it is not possible to reach truth through experience, which reproduces sensible data that are not sure, nor through the reason, which depends also upon the sensible data. To suspend judgment is the source of tranquillity and happiness.

In our society, people seek tranquillity and eliminate all that can create sorrow and fears. Agnosticism is a attitude widely diffused among Western people.

\section{Renaissance and the centrality of Human Beings}

The Renaissance began in the second part of the fourteenth century in Italy. It was a movement in which writers, historians, philosophers, and politicians participated. During the Middle Ages, individuals were oriented toward the supernatural and subordinated to the authority of the Church. Renaissance separated truth from all authoritarian principles and made the gap deeper between the supernatural and the natural world.

The philosophical Renaissance marks the beginning of modern philosophy. It had two basic tendencies: (1) humanism, according to which scholars turned back to study ancient writers, but with a new spirit; (2) naturalism, according to which nature was directly observed and studied by human reason. Humans sought for the source of being in 
nature rather than in a supernatural order.

During this period, men wanted to resume the position of primacy that they had during the classic age, when they occupied the center of the universe and were protagonists of human history. In the ancient religious mysteries human beings were symbolically represented by the mythic figure of Prometheus, who gave to them the ability to determine freely their position in the world.

The Renaissance was not only a philosophical movement. All fields of human knowledge were pervaded by the new spirit. The combined influences of economic wealth, political dynamism, majestic art, and the new discovery of the ancient world spread a secular spirit in the Italian ruling class, especially in the Medici family, who made Florence the center of the Renaissance.

A spirit of secularity, individualism, multiplicity of cultural interests, and creativity rapidly spread from Italy to all of Europe, forming a new mentality in modern Western people. The states became secular, cultural, and political units. Many religious institutions, such as marriage, became secular and lost their sacramental character.

The new sense of intellectual capacity, of spiritual power, reached the point where nature occupied the place of the deity. 
It was the Reformation that would recognize all the infringements on orthodox Christian dogma that the Humanist movement was encouraging--nature as immanent divinity, pagan sensuousness and polytheism, human deification, universal religion--and would therefore call a halt to the Renaissance's Hellenization of Christianity. ${ }^{1}$

\section{The Birth of Secular Political Man}

In the fifteenth and sixteenth centuries the decay of the feudal society and the rise of political absolutism began. In that time several absolute monarchies were formed.

Machiavelli (1469-1527 A.D.), an Italian political philosopher, emphasized monarchical absolutism in an Italy divided into many little states.

He is celebrated for his attitude of indifference toward ethics. According to him, politics and ethics must be separated from each other. He believed that a monarch is not bound by traditional ethical norms. In his view, he should be concerned only with power and be bound only by rules that would lead to success in political actions.

It was Machiavelli who made secularism a universal ideology. . . . The key of modernity will be found in Chapter 15 of The Prince. There Machiavelli lists ten pairs of qualities for which men, especially rulers, are praised or blamed. Astonishingly, no mention is made of wisdom, justice, moderation, and courage!. . . "Cunning" replaces wisdom, while "fierceness" replaces courage. (Today, in sophisticated democracies, wisdom

'Tarnas, The Passion of the Western Mind, 218 . 
and cunning have metamorphosed into "pragmatism.") 1 This separation of morality from politics makes Machiavelli the creator of secular political man.

\section{British Empiricism}

Rationalism and Empiricism are two opposite forms of knowledge, which fought against each other. In modern times on the European continent, Rationalism took advantage of Empiricism. England was the soil where Empiricism found its most important and influential champions, in Hobbes, Locke, and Hume. In opposition to Cartesian rationalism, the British empiricists emphasized that sensory experience was the unique source of knowledge.

According to Thomas Hobbes (1588-1679 A.D.), philosophy must deal only with the properties of bodies and with their origins. It excludes the teaching of God, because He is eternal. Hobbes was a convinced materialist. He believed that knowledge is a mere process of adding or subtracting perceptions one to another and getting the results. Words are signs or symbols of perceptions. Human beings use them as means of communicating their perceptions one to another.

He found the origin of religion in the natural curiosity of man and his desire for an explanation of

\footnotetext{
${ }^{1}$ Eidelberg, Beyond the Secular Mind, 7, 8 .
} 
natural phenomena. According to him, in the theology of developed religions there are many contradictions and, in the priestly caste, hypocrisy and selfishness.

Locke (1632-1704 A.D.) underlined the importance of experience of the senses in pursuit of knowledge. According to him, in the process of human knowledge there are three factors: the mind, the physical object, and the perception.

Locke, who accepted the old adage Nihil est in intellectu quod non fuit prius in sensu, believed that all ideas derive from experience and rejected the theory of innate ideas.

A human being knows the object only through his perception, which represents the object in the mind. It is not possible to be sure if the impressions, which the mind receives from outside, are related to a real and external world.

First, human beings perceive and feel; afterward they think about what they perceive and feel. The perceptions do not disappear, but leave their mark. Thus minds can compare and distinguish similarities and differences. Afterward, minds compose their elements in arrangements not given in sensation, and finally abstract general ideas.

Hume (1711-1776 A.D.) made a distinction between sensory impressions and ideas. Impressions are supplied by 
the senses, including the internal sense; ideas are recollections of previous impressions. Human minds combine the material acquired from experience and form ideas.

Hume calls impressions the vivid and direct stimuli of the senses and ideas the faint copies of those impressions. The contents of consciousness originate in sense experience. He, like Locke, rejected the existence of "innate ideas."

In a revolutionary step in the history of philosophy, Hume rejected the basic idea of causality. Knowledge is based on a continuous volley of sensations, on which the mind imposes an order. The association of ideas made by the mind is only a habit of the human imagination. The mind assumes this association as a causal relation, but really this causal nexus has no basis in a sensory impression and no existence outside the human mind. For an internal habit the mind interprets the repeated conjunction of events as a causal relation.

With Hume, the long-developing empiricist stress on sense perceptions, from Aristotle and Aquinas to Ockham, Bacon, and Locke, was brought to its ultimate extreme, in which only the volley and chaos of those perceptions exist, and any order imposed on those perceptions was arbitrary, human, and without objective foundation. . . . In the long evolution of the western mind from the ancient idealist to the modern empiricist, the basis of reality had been entirely reversed: Sensory experience, not ideal apprehension, was the standard of truth--and that truth was utterly problematic. Perceptions alone were real for the mind, 
and one could never know what stood beyond them. ${ }^{1}$ Hume's rejection of causation implies a rejection of scientific laws, which are based on the general premise that one event necessarily causes another.

\section{Enlightenment}

The period known as the Enlightenment placed great emphasis on human, rational capability and considered the human mind capable of discerning and knowing the structure of the external world. The thinkers of the Enlightenment postulated that the universe was a realm ordered by natural laws. Humans must be free of any external authority. Autonomy did not mean license, because nature and human beings are ruled by universal natural laws. Enlightenment was also an era of optimistic belief in the progress of humanity.

During the Enlightenment, culture was extended to the greatest number of individuals possible through dictionaries and encyclopedias. It was a movement opposed to all forms of traditions in ideological, ecclesiastical, social, and political fields. In the name of human beings, human rights, nature, reason, and science, people fought against every traditional principle which justified oppression of

\footnotetext{
1Tarnas, The Passion of the Western Mind, 339, 340.
} 
human beings. The philosophers of this period believed that nature and reason qualified the human being into a perfect being.

\section{Deism}

In the eighteenth century, under the influence of the Enlightenment, there arose in England among intellectuals a natural religion called deism.

The scientific progress, reached in physics and astronomy, gave to humanity a new image of the universe. The universe was conceived as a perfect cosmic machine, which proceeds with absolute regularity and without any possible interruption.

Deists attempted to offer a different image of God. According to them, God created an independent and lawabiding world, which works by itself, without any intervention from Him.

Deism accepted God, but denied that He providentially guides the world or intervenes in any way in the history of humanity. Human events develop according to precise laws and are determined by causes and effects.

According to Deists, the human being by his reason can find evidence of the existence of God. Religion was converted into a natural religion, the religion of freethinkers, which was considered the only true religion. 
All other religions leaned on mere superstitions instead of reason.

\section{Hegel and Absolute Idealism}

In Hegel (1770-1831), German idealism reached its highest apogee. Kant's philosophy was the starting point for the philosophy of Hegel.

According to Kant, the categories of the mind provide the form by which objects are known. But what is the content of these objects? Hegel tried to answer this question. The thoughts of human beings are the same as those of the World-Mind, the Mind who creates things by thinking them. In the Mind, thought, truth, and being perfectly coincide.

The Absolute Mind is the conscious process of thinking. The reality is a process. Thinking and being are unique and the same activity, just as I am what I think myself to be. The Absolute is spirit. The Absolute is a reality that, even if it becomes constantly all things, remains always identical to itself. Hegel conceived the Absolute as a self-developing process.

Since Hegel's Absolute is a Process and a Career, the concept of becoming, in which relative being and relative not-being are continually being related, aufgehoben, and synthesized, is the fundamental concept of his philosophy. It reveals, too, more clearly the ultimate triad. . . to which everything that exists is reducible. Thesis, antithesis, and synthesis--these 
mark all movement, all change, all life, all thinking. Becoming, then, is the first living notion.

According to Hegel, every being is spiritual reality. The eternal idea realizes itself as Absolute Spirit, who realizes himself through the dialectical triple passage of thesis, antithésis, and synthesis.

Also, according to Hegel, the history of humanity develops according to the law of the dialectical triad (thesis, antithesis, and synthesis). The opposite phases of the thesis and the antithesis unite in the final phase of synthesis.

Later philosophers gave different interpretations to the religious thought of Hegel. According to some philosophers, Hegel preserved the idea of God; others found a pantheistic interpretation of reality in his philosophy; and according to others, in his philosophy God was no more than an empty name. This last trend, called "the Hegelian left," flowed into materialism: Feuerbach, Marx, and Engels, who denied the existence of God.

\section{Pragmatism}

Pragmatism is the most characteristic and significant American philosophical movement. William James (1842-1910),

${ }^{1}$ B. A. G. Fuller, A History of Philosophy (New York: Holt, Rinehart and Winston, 1960), 2:313. 
an American philosopher, is usually considered as a founder of pragmatism.

According to James, rationalists look at principles, while empiricists observe facts. Rationalists move from the universal to the particular. They deduce facts from principles. Empiricists begin with facts, from which to induct principles.

According to him, individuals who investigate are always exposed to the danger of error. But the most important thing is to consider the practical advantages. When two persons propose different theories, the pragmatist will examine the practical consequences of each. If he can find no difference between them, the difference really is only verbal and further discussion is meaningless.

James sought to protect the life-values of religion, because, as experience only too thoroughly testifies, they have actually contributed both to man's education and to his welfare. If religious ideas are not actually demonstrable knowledge, they are at least extremely practical. ${ }^{1}$

Theism guarantees an ideal order and contributes to the education of the human being and his welfare. This does not mean that there is any evidence in support of theism. But the evidence for God lies primarily in inner personal experience.

${ }^{1}$ Johannes Hirschberger, The History of Philosophy (Milwaukee: Bruce Publishing Company, 1958), 2:528, 529. 
Cox considered that pragmatism is one of the motifs that characterizes the style of the secular city. Secular people do not occupy themselves much with mysteries, but they are concerned with the practical results. ${ }^{1}$

\section{Existentialism}

Marx and Kierkegaard represent two different kinds of revolution. Marx represents the socialistic revolution against a bourgeois society; Kierkegaard, a revolution within the Christian Church.

According to Kierkegaard (1813-1855), the important thing is a completely human life, not a life of pure knowledge. There is in every human being an exigency of existing. The life of a human being advances from one situation to another, and he must jump from one to another. According to Kierkegaard, the truth is not rational, but paradoxical.

He wrote:

Without risk is no faith. Faith is precisely the contradiction between the infinite passion of the individual's inwardness and the objective uncertainty. If I can grasp God objectively, I do not believe, but precisely because I cannot do this I must believe. - . The eternal essential truth is by no means in itself a paradox; but it becomes paradoxical by virtue

${ }^{1}$ Cox, The Secular City, 52 . 
of its relationship to an existing individual. ${ }^{1}$

Kierkegaard exercised an influence on existentialist philosophers. ${ }^{2}$ Some of his themes, divorced from their religious context, have been employed in atheistic existentialism.

\section{Heidegger}

Heidegger (1889-1976), a German philosopher, was especially influenced by Soren Kierkegaard. In his most important and influential work, Being and Time (1927), Heidegger was concerned with what he considered the essential question: What is man? This led to other questions of what kind of being human beings have.

He attempted to analyze Dasein, which is a term that refers to the manner of human existence. Dasein means being there, existence.

Animals and inanimate things are localized in space and time, but they do not exist. Only human beings exist, because only they are conscious of their existence. True being involves not only consciousness, but responsibility.

Human beings are thrown into a world that they have not

${ }^{1}$ Soren Aaby Kierkegaard, The Difficulty of Being

Christian, ed. Jacques Colette (Notre Dame, IN: Univerity of Notre Dame Press, 1968), 204, 205.

${ }^{2}$ Euller, A History of Philosophy, 2:603. 
made. The objects and artifacts come to humanity from the past and are used in the present for the sake of future goals. Humans are always in danger of being submerged in the world of objects and in the routine and conventional behavior of the crowd. The feeling of anguish and dread brings human beings to a confrontation with death, and only in this confrontation can an authentic sense of being and of freedom be achieved.

Heidegger showed in his important work, Sein und Zeit, how it was essential to approach the nature of being from the standpoint of time. According to him, modern technological society has manipulated humanity and deprived human life of meaning. Humanity has forgotten its true vocation and must recover the deeper understanding of being. He believed, however, that the ancient metaphysics of essence was static and incapable of giving an answer to contemporary problems.

According to him, human beings need the particular Western concept of being. Dread is the experience of nothing.

In dread our Dasein projects into nothing, but it is only in the transcendence of Dasein as projected into nothing that pure being is revealed. As Hegel had said, pure being and pure nothing are one and the same. Nothing is a primordial being, the ground from which 
everything comes and to which it must return. ${ }^{1}$

Heidegger repudiated existentialist interpretations of his work. Heidegger's philosophy, however, was associated with existentialism and he had a crucial influence on the French existentialist, Jean Paul Sartre.

\section{Sartre: An Atheistic Existentialist}

Sartre (1905-1980), a French philosopher, was an atheistic exponent of existentialism. According to him, the most important thing for the human is freedom. Human freedom for Sartre must be absolute. He wrote:

Toward 1880, when the French professors endeavored to formulate a secular morality, they said something like this: 'God is a useless and costly hypothesis, so we will do without it. . . . In other words . . nothing will be changed if God does not exist; we shall rediscover the same norms of honesty, progress and humanity, and we shall have disposed of God as an outof-date hypothesis which will die away quietly of itself.' The existentialist, on the contrary, finds it extremely embarrassing that God does not exist. ${ }^{2}$

For Sartre, humans have nothing fixed: there are neither truths, nor values, nor God. Human beings, surrounded by nothing, find themselves alone, and this condition leads to anxiety and converts their lives into a tragedy

${ }^{1}$ Ibid., $2: 609$.

${ }^{2}$ Jean-Paul Sartre, Existentialism and Humanism, trans. Philip Mairet (London: Methuen \& Co., 1965), 33. 


\section{God Is Dead}

Nietzsche (1844-1900), a German philosopher, described human life as terrible and tragic; he died in 1900, but his influence was not fully felt until the present century. He also influenced modern thought profoundly by his radical rejection of religion. Like Marx and Kierkegaard, Nietzsche also realized the decadence of the Christian bourgeois world and tried to reach new horizons.

According to him, it is necessary to eliminate all ideals imposed by society that hinder the growth of the human being: all philosophies, ethics, and theologies must fall. God also ought to be eliminated, because He hinders the development of humanity.

The works of Nietzsche are an overflowing literary delirium. He used vigorous, sometimes even brutal, expressions. For him, life is irrational; it is sorrow, pain, and horror. Philosophers, scientists, and theologians try to understand life, but really the only thing they have done is to mask reality, obstructing the authentic energies of human beings.

The idea of 'God' is contrary to the idea of life, because God is an obstacle to the growth of mankind. Nietzsche wrote:

The concept 'God' invented as the antithetical concept 
to life--everything harmful, noxious, slanderous, the whole mortal enmity against life brought into one terrible unity! The concept 'the Beyond', 'real world' invented so as to deprive of value the only world which exists--so as to leave over no goal, no reason, no task for our earthly reality! The concept 'soul', 'spirit', finally even 'immortal soul', invented so as to despise the body. ${ }^{1}$

Nietzsche condemned the ethics created by weak persons with the purpose of protecting themselves from strong persons. Instead of this ethics of the weak and of slaves, humans need the ethics of strong, powerful, vigorous persons--the ethics of the superman. Nietzsche described race, lifestyle, strength, and courage of the superman. In order for the superman to live, it is necessary to eliminate God. Nietzsche said: "God died; and.. . so that the superman might live."2 According to him, belief in God is hostile to human life, and the decay of belief in God opens the way for man's creativity.

Nietzsche has been called the crazy prophet of our time. Nevertheless, he realized that by announcing the death of God, human beings faced a difficult alternative: either to substitute something else for God or to fall into deeper despair, knowing God to be nothing.

\footnotetext{
${ }^{1}$ Friedrich Nietzsche, Ecce Homo (Harmondsworth,
} Middlesex, England: Penguin Books, 1979), 133.

${ }^{2}$ Hirschberger, The History of Philosophy, 2:504. 
The thought of Nietsche influenced Western people. Today many secular people think that religion is an obstacle to their development. They want to be "free." They desire to take the decisions of their life upon themselves. According to some, God hinders them from improving their position in society and from reaching a good economic standard.

\section{Agnosticism of Bertrand Russell}

Many intellectuals believe that God is a metaphysical illusion, created by human beings. However, not all intellectuals are atheists; many are agnostics.

Typical is the example of the British scientist and philosopher, Bertrand Russell (1872-1970). Russell clarified his position in a debate with Copleston on the existence of God transmitted by the British Broadcasting Corporation in 1948.

Copleston asked Russell: Well, my position is the affirmative position that such a being actually exists, and that His existence can be proved philosophically. Perhaps you would tell me if your position is that of agnosticism or of atheism. I mean, would you say that the non-existence of God can be proved?

Russell: No, I should not say that: my position is agnostic. . . . Well, I'm not contending in a dogmatic way that there is not a God. What I'm contending is that we don't know that there is. ${ }^{1}$

${ }^{1}$ Bertrand Russell, Bertrand Russell on God and Religion (Buffalo, NY: Prometheus Books, 1986), 123, 135. 
Russell was an agnostic. He did not believe that there is any possibility of proving either the existence or the non-existence of God. He tried to confute the proofs used to demonstrate the existence of God. He wrote:

To come to this question of the existence of God, . . . perhaps the simplest. . . is the argument of the First Cause. . . Everything we see in this world has a cause, and as you go back in the chain of causes further and further you must come to a First cause. - . I for a long time accepted the argument of the First Cause, until one day, . . I read John stuart Mill's Autobiography, and I there found this sentence: "My father taught me that the question, Who made me? cannot be answered, since it immediately suggests the further question, Who made God?" That very simple sentence showed me, as I still think, the fallacy in the argument of the Eirst Cause. If everything must have a cause, then God must have a cause. If there can be anything without a cause, it may just as well be the world as God. . . . It is exactly of the same nature as the Indian's view, that the world rested upon an elephant and the elephant rested upon a tortoise; and when they said, "How about the tortoise?" the Indian said, "Suppose we change the subject." 1

Two observations can be made about the arguments that

B. Russell made on the First Cause. On the one hand, the First Cause is not called First because it opens a series of causes, of which it is the first. First Cause means cause for excellence, which is a transcendent condition of all causality. God transcends the universe, He is completely different from the phenomenological world. The god of whom B. Russell spoke is a pantheistic god, who is part of the

$$
{ }^{1} \text { Ibid., 59, } 60 \text {. }
$$


universe and is submitted to the same causality of all that is inside it. The God of the Bible is a transcendent God and therefore not subject to the laws that rule the universe.

On the other hand, it is true that the universe can be eternal, but it is necessary to prove that. When one says God is eternal, he enunciates an analytic judgment, that is to say, a judgment that affirms what is already contained in the subject-concept.

In short, the word God contains the concept of eternity within it. That is why the word Yahweh, which is used in the Bible to indicate God, is often translated "the Eternal," and all people, when they say the Eternal, know clearly that they are speaking of God.

It is not the same for the concept of the universe. The judgment, the universe is eternal, is a synthetic judgment that must be demonstrated, because the conceptpredicate adds something to the concept subject that is not necessarily implied in it.

On the other hand, nobody can demonstrate that the universe is eternal. In spite of what has been observed, many secular people often use the arguments employed by Bertrand Russell. 


\section{The Postmodern Mind}

The early prophet of the postmodern mind is Nietzsche, who anticipated the emerging nihilism in Western culture. Like Nietzsche, the postmodern intellectual situation is profoundly complex and ambiguous.

Jean-François Lyotard in The Postmodern Condition ${ }^{1}$ tries to clarify the meaning and extent of this condition. According to Lyotard, in the last decades the problems that science and technology have tried to resolve are relative to communication, translation, information storage, and data banks.

The new technology of computers has changed the way in which learning is acquired, classified, and made available.

Along with the hegemony of computers comes a certain logic. . . The old principle that the acquisition of knowledge is indissoluble from the training (Bildung) of minds, or even of individuals, is becoming obsolete and will become ever more so. . . . Knowledge is and will be produced in order to be sold, it is and will be consumed in order to be valorized in a new production: in both cases, the goal is exchange. ${ }^{2}$

Thus, knowledge is today produced in order to be sold. Computerized knowledge has become the principal force of

IJean-Erançois Lyotard, The Postmodern Condition: A Report on Knowledge (Minneapolis: University of Minnesota Press, 1993).

${ }^{2}$ Ibid., 4 . 
production. Today knowledge is the most important component in world competition. Some people already imagine that the nations will soon fight for the control of information.

The hegemony of computers has brought new logic, a new set of prescriptions, which determines the kind of knowledge necessary for society.

There is an increase in the number of professional, technical, and white-collar employees of computation. In the last decades, according to Lyotard, the multinational corporations constitute the new economic power, which take decisions beyond the control of the nation-states.

This creates a problem of legitimation, i.e., of finding the criterion by which to establish the kind of knowledge that must be produced. Lyotard, influenced by Wittgenstein, suggests that this problem is related to the pragmatic aspect of language. Each of the various categories of utterance can be defined in terms of rules of language games. He makes these three following observations about language games.

The first is that their rules do not carry within themselves their own legitimation, but are the object of a contract, explicit or not, between players (which is not to say that the players invent the rules). The second is that if there are no rules, there is no game, that even an infinitesimal modification of one rule alters the nature of the game, that a "move" or utterance that does not satisfy the rules does not belong to the game they define. The third remark is suggested by what has just been said: every utterance 
should be thought of as a "move" in a game."

According to Lyotard, scientific knowledge does not represent the totality of knowledge. It has always existed in addition to, and in conflict with, another kind of knowledge, called by Lyotard narrative. The set of rules about truth, justice, and beauty, transmitted by narrative knowledge, is often woven together and constitutes the social bond of a society.

There are particular cognitive procedures associated with scientific knowledge. The scientists who transmit scientific knowledge must be able to provide proofs or, at least, to refute any opposing or contradictory statements concerning the knowledge transmitted. There are two kinds of rules: verification, the criterion of the nineteenth century, or falsification, the criterion of the twentieth century. But these criteria are not sufficient. For example, the criterion of falsification of Popper affirms that only the empirical disproof of a theory is conclusive, while any amount of evidence in favor of a particular theory remains inconclusive. But, according to peter Lipton, this criterion is insufficient. He wrote:

There is no reliable route to falsification that does not use induction. . . . Scientists also need inductive methods that yield positive results if their negative

${ }^{1}$ Ibid., 10. 
methods are to be reliable. . . Induction is unavailable, so Popper's solution to the problem of induction fails. . . . If science generates knowledge at all, it can only do so by determining what is false; but if it can determine what is false, it can also determine what is true. ${ }^{1}$

According to the criterion of verification, Lyotard observed that a statement of science gains no validity from the fact of being reported. Really in itself is never secure from "falsification."

According to Lyotard, scientific knowledge requires that one language, denotation, be retained and all others excluded.

Both scientific and narrative knowledge are equally necessary; both are composed of sets of statements, which are 'moves' made by the players within the framework of generally applicable rules. Scientific knowledge must resort to narrative for its legitimation.

Scientific knowledge cannot know and make known that it is the true knowledge without resorting to the other, narrative, kind of knowledge, which from its point of view is no knowledge at all. Without such recourse it would be in the position of presupposing its own validity and would be stooping to what it condemns: begging the question, proceeding on prejudice. But does it not fall into the same trap by using narrative as its authority? ${ }^{2}$

${ }^{1}$ Peter Lipton, "Popper and Reliabilism," in Karl Popper: Philosophy and Problems, ed. Anthony O'Hear (Cambridge: University Press, 1995), 43.

${ }^{2}$ Lyotard, The Postmodern Condition: A Report on Knowledge, 29. 
As we have seen, the new system through which knowledge is transmitted, the system of computerization, has created the problem of legitimation of knowledge produced and spread by the multinational corporations. We have also seen that it is not possible to separate scientific knowledge from narrative, because the first needs the second in order to prove its legitimation. The results of all this are fragmentation and pluralism.

Not only Lyotard but other postmodernists as well stress fragmentation and pluralism of knowledge. They repudiate the big stories, the meta-narratives of Hegel and Marx. They adopt a pluralistic outlook wherein each litigant respects the other's difference of viewpoint and the diversity of language games.

What is called postmodern varies considerably according to context, but. . . the postmodern mind may be viewed as an open-ended, indeterminate set of attitudes that has been shaped by a great diversity of intellectual and cultural currents; these range from pragmatism, existentialism, Marxism, and psychoanalysis to feminism, hermeneutics, deconstruction, and postempiricist philosophy of science, to cite only a few of the more prominent. ${ }^{1}$

In addition to its divergent impulses and tendencies, postmodernism is characterized by a general appreciation of the plasticity and constant change of understandings and knowledge. It recognizes that knowledge is subjectively

${ }^{1}$ Tarnas, The Passion of the Western Mind, 395. 
determined by many factors and the value of all assumptions must be constantly subjected to testing. Since knowledge is relative and fallible, it is necessary to always be ready to admit one's errors.

Reflecting and supporting all these developments is a radical perspectivism that lies at the very heart of the postmodern sensibility: a perspectivism rooted in the epistemologies developed by Hume, Kant, Hegel (in his historicism), and Nietzsche, and later articulated in pragmatism, hermeneutics, and poststructuralism. - . The subject of knowledge is already embedded in the object of knowledge: the human mind never stands outside the world, judging it from an external vantage point. . . All human knowledge is mediated by signs and symbols of uncertain.provenance, constituted by historically and culturally variable predispositions, and influenced by often unconscious human interests. Hence the nature of truth and reality, in science no less than in philosophy, religion, or art, is radically ambiguous. ${ }^{1}$

Postmodern intellectuals generally think that all human thought is ultimately a cultural product. Language is a cage. Human experience is pre-structured. No interpretation of a text can claim to be decisive, but text refers to other texts in an infinite regress.

Spurred by these and other, related factors, postmodern critical thought has encouraged a vigorous rejection of the entire Western intellectual "canon" as long defined and privileged by a more or less exclusively male, white, European elite. . . Under the cloak of Western values, too many sins have been committed. Disenchanted eyes are now cast onto the West's long history of ruthless expansionism and exploitation--the rapacity of its elites from ancient times to modern, its systematic thriving at the expense of others, its colonialism and

${ }^{1}$ Ibid., 397 
imperialism, its slavery and genocide, its antiSemitism, its oppression of women, people of color, etc. ${ }^{1}$

The pretense of omniscience can no longer be sustained. Many times the absolutistic systems of thought that assert to possess the truth really mask a relationship with economical and political powers, which try to dominate through intellectual authoritarianism, psychical violence, and empirical falsification.

\section{The Gradual Fall of Human Certainties}

In this chapter we have seen the philosophical theories that have further contributed to the formation of the process of secularization.

Many fundamental concepts, which are found in Western culture, come from Greek philosophy. Ontological and anthropological dualism, a pantheistic vision of reality, rationalism, materialism, relativism, formal logic, and skepticism are already present in Greek philosophy, at least in embryonic form.

The development of the theories of universals (ante res, in rebus, post res) in medieval times, which led to nominalism, the centrality of the human being of Renaissance, the emphasis during the Enlightenment on human

\footnotetext{
${ }^{1}$ Ibid., 400
} 
reason and Empiricism, the natural religion of deists which separated God from human affairs, the pragmatism which pushed human beings to mind only what produces immediate results, atheistic existentialism, the superman of Nietzsche who must eliminate God in order to improve his life, and postmodernism with fragmentation and pluralism, all these philosophical trends have contributed to the formation of the Western contemporary secular mind.

A rapid glance over the philosophies that have contributed to the formation of the process of secularization has allowed us to realize that with the elimination of God from human culture also other human certainties fall.

Greek philosophy exalted human reason and contributed to the formation of the intellectual Western human being. Medieval nominalism transformed the universals into simple names.

With the Renaissance, nature gradually took on the pattern of a machine (natura naturata), which functioned by fixed laws laid down to the same nature (natura naturans). British Empiricism limited human knowledge to sense experience. Locke, following a tendency already existent in British culture (Ockham, Bacon, and Hobbes), strongly reaffirmed that human knowledge began with sense experience 
and does not go beyond it. However, he could not escape the influence of Descartes and admit that to know is to have ideas, images, the impression of human conscience.

But for Hume these impressions were mere perceptions, disconnected from one another, and nothing more. Human beings rightly asked who or what assured them that beyond those impressions anything else really exists? God?

But "the Hegelian left" (Feuerbach, Marx, Freud), as we will see in chapter 4, denied the existence of God. They claimed that human beings no longer need God. The atheistic or agnostic tendency always became more strong.

With postmodernism not only the idea of God falls, but also human certainties collapse, and the contemporary human being is disoriented and confused. Not only narrative knowledge but also scientific knowledge has no certain support. Many think that all human knowledge is reduced to language games, which change with the change of human beings in time and space.

\section{Summary}

In this chapter we have seen the philosophical theories that have contributed to the formation of the process of secularization.

We have seen how Greek, medieval, modern, and contemporary philosophers have contributed to the rise and 
formation of the secular mind. However, the indifference toward religion of secular people is not only the consequence of these philosophical theories, but also of some theological trends.

In chapter 4 the theological systems that have contributed to the development of this process are considered. 
CHAPTER IV

THE THEOLOGICAL THEORIES THAT CONTRIBUTED TO

THE FORMATION OE SECULAR INTELLECTUAL MAN

\section{Introduction}

In this chapter some theological theories that have contributed to the formation and the development of the process of secularization are considered. In particular, the critiques against the existence of God expressed by some thinkers and the theology of secularism are examined.

It may seem strange that theological systems, which ought to teach people to live in an intimate relationship with God, can be influenced by secular movements and have contributed to the formation of the secular mind-set, but, as Bonhoeffer wrote, also in religion "God as a working hypothesis" has been surmounted.

God as a working hypothesis in morals, politics, or science, has been surmounted and abolished; and the same thing has happened in philosophy and religion (Eeuerbach!). ${ }^{1}$

Secular theology in our times has obviously influenced

${ }^{1}$ Dietrich.Bonhoeffer, Letters and Papers from Prison, ed. E. Bethge (New York: Macmillan Company, 1967), 195, 196. 
the secular mind.

\section{Syncretism and the Origin of Medieval Christianity}

In the first centuries of the Christian Era, paganism and Christianity contaminated each other. Understanding what happened to Christianity is important, because some philosophical ideas, which Christianity received from paganism, contributed to the formation of Western culture and consequently secular thought.

The contamination of Christianity by paganism began very early in its history. In order to preach the gospel to the Greco-Roman world, translation of the biblical message into Greek was necessary. Christians adapted it to the preexistent Greek forms of thought. Christians also absorbed cultural, artistic, political, juridical, economical, and social forms of Greco-Roman thought and used the categories of Greek philosophy to interpret and express biblical thought.

Alyward Shorter, president of the Catholic Missionary Institute of London, wrote:

When, in the fourth century, Christianity became the official religion of the Roman Empire and the same Roman Emperor became a Christian, the Church adopted the imperial, Roman view of culture. This view was even more strongly reinforced when the Pope, in the fifth century, effectively became an heir to the 
extinct line of western emperors. ${ }^{1}$

After the conversion of Constantine, Christianity became, little by little, a state religion. Christian emperors inherited the intolerance of pagan emperors. The Roman view of culture was a universal ideal of civilization. Its opposite view was considered savagery or primitiveness. The entire human race was divided into two camps: one cultured and civilized; the other uncultured and barbarian.

The Church and the Empire became one politico-religious system. The Greco-Roman philosophy was applied to the biblical message.

Before the persecutions began, there was syncretism. - . This syncretism spread from Alexandria. . and was represented by the second series of Fathers of the Church, Clement of Alexandria (217 A.D.) and Origen (254 A.D.). . . Now, this speculation, oriented toward Neoplatonism, introduced into Christianity a system of degrees and steps under the form of a large number of mediators: angels, martyrs, saints. ${ }^{2}$

Pagan Neoplatonism impregnated Christian philosophy and theology more and more. The hierarchical universe of the Neoplatonic philosopher proclus served as a model for the heavenly and ecclesiastic hierarchies of Pseudo-Dionysius, which passed through him to Christianity.

${ }^{1}$ Aylward Shorter, Toward a Theology of Inculturation (Maryknoll, NY: Orbis Books, 1988), 18.

${ }^{2}$ Alfred Weber, Historia de la Cultura (Mexico D.F., Buenos Aires: Fondo de Cultura Economica, 1960), 141, 142 (translation mine). 
In the Middle Ages polytheistic religion disappeared, replaced by three great monotheistic religions: Judaism, Christianity, and Islam.

Greek philosophy strongly influenced medieval thought, which was generally blended with religious faiths. Many of the great trends of Greek philosophical thought (Pythagoreanism, Platonism, Aristoteliansm, etc.) in one manner or other were present in the Middle Ages.

Platonism and Aristotelianism influenced Islam. In the thirteenth century Islamic thinkers influenced Christian thinkers, transmitting to them the works of Aristotle.

Later, in the Middle Ages the platonic dualism between matter and spirit was developed into a series of dichotomies within Christianity: God, pure spirit, was opposed to the material world; the spiritual soul to the material body; the spiritual work to the material; the laity to clergy, etc.

The medieval world was ordered according to this worldview. The Church, a spiritual institution, was considered superior to the state. Philosophy became the ancilla of theology; the laity an inferior status to the clergy. The Church became the infallible holder of the Truth and established what people ought to believe, not only in religion but also in political, economical, ethical, and scientific matters. 
Our Western culture has inherited from the Middle Ages this Platonic dualism, which separated body from spirit and natural from supernatural.

In its more extreme forms, Platonism encouraged in Christianity a view of the body as the soul's prison. As with the physical body, so with the physical world. Plato's doctrine of the supremacy of the transcendent reality over the contingent material world reinforced in Christianity a metaphysical dualism that in turn supported a moral ascetism. ${ }^{1}$

This dualism creates serious problems for the missionaries who preach in non-Christian countries, where people have a holistic worldview and do not understand the dualistic message.

Paul G. Hiebert wrote:

I have excluded the middle level. . . As a scientist, I had been trained to deal with the empirical world in naturalistic terms. As a theologian, I was taught to answer ultimate questions in theistic terms. For me the middle zone did not really exist. . . How did this two-tier world view emerge in the West? Belief in the middle level began to die in the 17 th and 18 th centuries with the growing acceptance of a Platonic dualism and with it, of a science based on materialistic naturalism. The result was the secularization of science and mystification of religion. . . . Science was based on the certitudes of sense experience, experimentation and proof. Religion was left with faith in visions, dreams and inner feelings. ${ }^{1}$

In our western society God and religion have been

${ }^{1}$ Tarnas, The Passion of the Western Mind, 140.

${ }^{1}$ Paul G. Hiebert, "The Flaw of the Excluded Middle," Missiology 10, no. 1 (January 1982): 43, 44. 
relegated to a supernatural world. In contemporary thought they have little to do with our natural world.

It is important to remember that secular people understand and judge the biblical message through the distorted glasses of Western culture.

\section{The Middle Ages and Nominalism}

In the late time of Scholasticism the philosophers did not share the confidence of Thomas Aquinas in the cognitional possibilities of human reason.

For example, William of Ockham (1300-1349 A.D.), an English philosopher, rejected the idea that the universals were ante rem (before the objects perceived) and in re (in the objects perceived). According to him, they do not have an ontological existence, do not exist either before, or in the objects that we perceive, but are only conventional signs, names by which we refer to a particular object (nominalism). Only the individuals exist. We cannot predicate the notion of man to socrates. We can say only that Socrates is Socrates. God creates individuals.

According to Ockham, the speculative rationalism of the earlier Scholastics was inappropriate. He cut the link between theology and the natural sciences. He proclaimed a new form of double-truth: one truth described by Christian 
revelation and another related to particular facts described by empirical and rational science.

Ockham's vision prefigured the path subsequently taken by the Western mind. For just as he believed the Church must be politically separated from the secular world for the integrity and rightful freedom of both, so he believed God's reality must be theologically distinguished from empirical reality. . . Herein lay the embryonic foundations--epistemological and metaphysical as well as religious and political--for coming changes in the Western world view to be wrought by the Reformation, the Scientific Revolution, and the Enlightenment. ${ }^{1}$

The nominalism and empiricism of Ockham spread in the universities of the fourteenth century, despite papal

censure. His philosophy was known as the via moderna, while Thomas Aquinas's philosophy was known as via antiqua. The enterprise of Scholasticism to join faith with reason was coming to an end.

\section{The Reformation}

The Renaissance also entailed a renewal in the religious field. However, only with Martin Luther, Ulrich Zwingli, John Calvin, and others was a real reformation of religious life possible.

It was when the spirit of Renaissance individualism reached the realm of theology and religious conviction within the Church, in the person of the German Augustinian monk Martin Luther, that there erupted in

${ }^{1}$ Tarnas, The Passion of the Western Mind, 208. 
Europe the momentous Protestant Reformation. ${ }^{1}$

Luther put human beings in direct and immediate relationship with God. Luther underlined the primacy of the individual response to Bible truth. Instead of the infallibility of the Church, Luther presented the infallibility of the Bible.

According to him, man did not need the magisterium of the Church. God helped man by the Holy Spirit to understand the Holy Scriptures. The Bible must be read by every individual. That is why it must be translated into language that people can understand. Luther translated the Bible into German.

The reformers believed that the Church had replaced faith in Christ with faith in the dogmas of the Church. According to them, it was necessary to come back to the pristine faith of early Christianity, which was founded on three fundamental principles: Sola Scriptura (The Bible is the unique source of Christian beliefs); Sola fide (Faith in Jesus Christ is the unique requirement for being saved); Sola gratia (Grace is the unique means used by God for saving human beings).

Even though Luther had been educated in the Scholastic tradition, he believed that natural theology was not

\footnotetext{
${ }^{1}$ Ibid., 233.
} 
possible because the total depravity of the human being. In fact, human reason is now as perverse as any other human faculty and therefore incapable of finding and knowing God without intervention of God's grace.

On the other hand, no connection was possible between the secular mind and Christian faith, because Christ's sacrifice on the cross was foolishness to human wisdom.

The Reformers made a clear distinction between Creator and creature, between God's transcendence and the world's contingency .

The Reformers underlined the transcendence of God and His separation from the world, and unawarely opened the way to a naturalistic view of the universe. They limited the human mind to worldly knowledge.

The world could be known no longer according to its participation in divine design but according to its own material processes. This opened the way to a new agnostic science of nature and a deistic secular conception of God.

\section{The Thirty Years' War and the Emancipation of the States from the Ties of Christianity}

Important effects were produced by the Thirty Years' War in Europe in the process of secularization. The Thirty Years' War (1618 to 1648) involved most of the countries of western Europe and was primarily based on the profound 
religious antagonism engendered among Germans by the events of the Protestant Reformation. Religious animosity between the contending protestant and Roman Catholic factions broadened the war and was a substantial factor in its later stages.

The Peace of Westphalia, signed at Münster on October 24, 1648, closed the Thirty Years' War, readjusted the religious and political affairs of Europe, and fundamentally influenced the subsequent history of Europe. The economic, social, and cultural consequences of the war were vast.

The provisions with respect to ecclesiastical affairs included the interdiction of all religious persecution in Germany and the confirmation of the Treaty of Passau (1552) and the religious Peace of Augsburg (1555). According to the treaty, the religion of each German state was to be determined by the religion of its prince.

The confessional wars produced effects in the political sphere: e.g., the emancipation of the states from the ties of the Christian churches. The states claimed authority over the lives of their citizens. In this period began the emancipation of the public life from religious ties, and the creation of two separate spheres: public and private. 


\section{Liberal Protestant Theology and Demythologization}

Another important religious movement that contributed to form a secular mentality was theological Liberalism. This movement was an effort to create a Christian theology acceptable to the new mentality of those times.

The pioneer of this theological movement was Schleiermacher (1768-1834), a philosopher and theologian, who defined religion as feeling and intuition of absolute dependence. A human being feels oneself as a finite entity, an individual totally dependent upon the Infinite God.

For him, Christian theology was not a description of objective truth, but rather a subjective religious experience expressed by figurative symbols. It is no longer necessary to believe in the objective validity of Christian theology. He underlined the emotional and symbolic aspect more than the historic aspects of Christianity.

In Schleiermacher we see the antithesis to Hegel's intellectualization of religion and to the moralization of religion in Kant. In spite of this, however, it is evident that the figure and the work of Kant are in the background of his reasoning. For God is posited again as subject in the sentiment he entertains. ${ }^{1}$

Later, Strauss (1808-1874) published his famous Life of Jesus, in which he tried to demonstrate that the Gospels are

${ }^{1}$ Hirschberger, The History of Philosophy, 2:390. 
not histories but poetry and myth.

The primary interest of Bultmann (1884-1974) was to communicate the Christian message to twentieth-century

people. In order to accomplish this purpose, it was necessary to demythologize biblical sources.

According to him, mythology was the form of imagery in which the divine was represented through worldly human realities. Hence demythologization was a particular method of hermeneutics.

With myth thus defined, that polysyllabic term, Demythologization, may now be explicated. Essentially, Bultmann declares, "It is a method of hermeneutics," which seeks to extract the kernel of insightful significance from the shell of an antiquated world view. "This method of interpretation of the New Testament which tries to recover the deeper meaning behind the mythological conceptions I call de-mythologizing--an unsatisfactory word, to be sure. Its aim is not to eliminate the mythological statements but to interpret them."

The purpose of New Testament writers was evangelistic, not historical. The Gospels must be demythologized, stripped of the mythological husk while keeping the pure kernel of truth that is inside it.

However, some theologians ask: how is it possible to believe that God has saved humankind through a Man whose

${ }^{1}$ Vernon C. Grounds, "Pacesetters for the Radical Theologians of the Sixties and Seventies," in Tensions in Contemporary Theology, ed. Stanley N. Gundry and Alan F. Johnson (Chicago: Moody Press, 1976), 50. 
historicity is very dubious and whose life is narrated to us through a mythological fog that only specialist scholars can penetrate?

But if one does not hear God speaking through Scripture, what then? History and logic are powerless to persuade. Bultmann on his premises cannot appeal to any internal testimony of the Holy spirit-another mythological concept! Hence, if modern man will not or cannot resort to a most unscientific voluntarism, his sole alternative is skepticism or atheism. ${ }^{1}$

\section{Arguments against the Existence of God}

Arguments against the existence of God made by intellectuals Iike Feuerbach, Marx, and Freud in the past century have certainly contributed to the indifference to religious values in the Western secular mind.

Homo positivus of the modern age, intellectually formed on the cultural indicators of scientific discoveries, tries to give life to a society in which the religious element--at least in the first moment--is not rejected, but brought from the transcendent sphere to a dimension wholly this-worldly. This secularization of religion, especially of the Christian religion, finds its brightest and most coherent radicalism in the thought of Ludwig Feuerbach. ${ }^{2}$

According to Feuerbach (1804-1872), in the beginning human beings associated the powerful destructive forces of nature with ghosts and supernatural beings, and venerated

${ }^{1}$ Ibid., 56 .

${ }^{2}$ Giorgio Campanini and Paolo Nepi, Cristianità e Modernità (Rome: Editrice A.V.E., 1992), 149 (translation mine). 
these forces as divinities. Later the concept of a personal God rose with the self-projection of human beings. God is man's projection of his own essence. Homo homini deus est. It is not God who created man, but man who created God.

For God did not, as the Bible says, make man in His image; on the contrary, as I have shown in The Essence of Christianity, man made God in his image. . . . Every God is a creature of the imagination, an image, and specially an image of man, but $\mathrm{He}$ is an image which man places outside himself and conceives of as an independent being. ${ }^{1}$

Religion is the relationship of the human being with himself. According to Feuerbach, this self-projection expresses man's alienation from himself.

Religion is the disuniting of man from himself; he sets God before him as the antithesis of himself. God is not what man is--man is not what God is. God is the infinite, man the finite being; God is perfect, man imperfect; God eternal, man temporal. ${ }^{2}$

Religion is the separation of man from himself; he sets God against himself as an opposed being. Eeuerbach attempted to reduce theology to anthropology.

Karl Marx (1818-1883) accepted the critique of Eeuerbach on religion, but he believed that Eeuerbach had not been radical enough. The same Marx wrote about the

${ }^{1}$ Ludwig Eeuerbach, Lectures on the Essence of Religion, trans. Ralph Manheim (New York: Harper \& Row, Publishers, 1967), 187 .

${ }^{2}$ Ludwig Feuerbach, The Essence of Christianity, trans. George Eliot (New York: Harper \& Row, Publishers, 1957), 33. 
thought of Eeuerbach:

Feuerbach resolves the religious essence into the human essence. The human essence is no abstraction inherent in each single individual. In its reality it is the ensemble of the social relations. . . Feuerbach, consequently, does not see that the "religious sentiment" is itself a social product, and that the abstract individual whom he analyzes belongs in reality to a particular form of society. ${ }^{1}$

According to Marx, religion was the product of a society based on wrong relationships of production. Religion is a form of alienation produced by a capitalist society, and at the same time a drug, which alienates the oppressed and exploited workers from their real situation, and hinders them from taking cognizance of their unjust and inhuman socioeconomic situation.

Marx believed that in every epoch the prevailing economic system determined the forms political, religious, ethical, intellectual, and artistic of social organization. According to him, human history is a perpetual process in which humans evolve. This perpetual becoming will interrupt itself when human society will surpass the contrast between capitalism and the proletariat. Marx had faith that the proletarians realize an ideal society without classes, in which the proletarians live in a new paradisiacal condition. The human being must trust in his

${ }^{1}$ Karl Marx and Friedrich Engels, On Religion (Chico, CA: Scholar Press, 1982), 71. 
own strength and not in a religion, which alienates him from his real condition and responsibilities. Marx contributed to the creation of a secular attitude of indifference toward religion.

Sigmund Freud (1856-1929), an Austrian neurologist, tried to find the origin of religion. According to him, religion is a neurosis of an obsessive type, a childish illusion created by the neurotic fantasy of the human being. The human feels the necessity of protection, creates gods, gives to them paternal features, and requests protection from them. Once adults, they learn to dominate this neurosis, and the illusion disappears.

Freud influenced and continues to influence many persons, especially intellectuals, who believe, as did Freud, that religion is an illusion, a neurosis. For many intellectual secular people only those who are ignorant can trust in religion which is built upon fears, anxieties, and hopes, without any rational foundation.

\section{Tillich Attempted to Mediate between Christian Theology and Modern culture}

For Tillich (1886-1965), an influential theologian of our time, the principal concern was to communicate the Christian message in terms intelligible to the modern human mind. 
First of all, according to him, it is necessary to eliminate a literalistic supernaturalism, which hinders the communication of the biblical message to modern people.

By his method of correlation, Tillich proposed to relate theology and philosophy.

Philosophy's task is to formulate questions of "ultimate concern"; . . theology's role is to dialogue with philosophy, understanding these questions, and coming up with satisfactory responses to them. "Therefore, the systematic theologian must be a philosopher in critical understanding even if not in creative power."1

Tillich offered, in his work systematic Theology, an existential analysis of being. He accepted the familiar description of the post-war era as an age of anxiety and described anxiety as the awareness of one's own transitoriness. But there was not only the anxiety of death, there was also the anxiety of emptiness, meaninglessness, guilt, and condemnation.

To lose one's destiny is to lose the meaning of one's being. . . The threat of possible meaninglessness is a social as well as an individual reality. There are periods in social life, as well as in personal life, during which this threat is especially acute. Our present situation is characterized by a profound and desperate feeling of meaninglessness. Individuals and groups have lost any faith they may have had in their destiny as well as any love of it. ${ }^{2}$

${ }^{1}$ David I. Smith, A Handbook of Contemporary Theology (Wheaton, IL: A BridgePoint Book, 1992), 78.

${ }^{2}$ Paul Tillich, Systematic Theology (Chicago: The University of Chicago Press, 1951), 1:201. 
Tillich sought to mediate between Christian theology and modern culture. One can accept or reject his intent, but one must recognize that Tillich was right when he insisted that it was necessary to avoid the isolation of Christian thought from the intellectual and cultural life of our time.

Tillich believed that Christian theology may incorporate the critical posture and scientific concepts of contemporary thought without endangering its Christian faith. He utilized the insights of deep psychology and existential philosophy in his attempts to renew the relevance of theology for modern secular society. However, Tillich "through his attacks on the God of theism helped prepare the way for a later generation of theologians" and also "undoubtedly helped nourish the God is Dead theology."1

\section{Before God but Without God}

In the 1960s, the prison writings of Dietrich Bonhoeffer (1906-1946), a young German Lutheran theologian, influenced many Christians.

According to Bonhoeffer, modern men want to be adults and to affirm autonomy in their knowledge and dominion of

${ }^{1}$ Grounds, Pacesetters for the Radical Theologians of the Sixties and Seventies, 96. 
the world. Scientists no longer require God as a working hypothesis. Human beings exclude God from human affairs, and even in the expression of religion God remains absent.

Man has learnt to deal with himself in all questions of importance without recourse to the 'working hypothesis' called 'God'. In questions of science, art, and ethics this has become an understood thing at which one now hardly dares to tilt. But for the last hundred years or so it has also become increasingly true of religious questions; it is becoming evident that everything gets along without 'God'.'

Bonhoeffer believed that this is the real situation in which human beings live and they cannot do other than to accept it. They must live in the face of God without God.

God would have us know that we must live as men who manage our lives without him. The God who is with us is the God who forsakes us (Mark 15:34). The God who lets us live in the world without the working hypothesis of God is the God before whom we stand continually. Before God and with God we live without God. ${ }^{2}$

As "adults" we must live etsi Deus non daretur (even God is not given). On the cross Jesus cried: "My God, my God, why have you forsaken me?" (Matt 27:46). Christ does not help us by His omnipotence, but by His weakness and His suffering.

Then, Bonhoeffer asked: "In a religionless time, how do we speak of God without religion?" He answered:

\footnotetext{
${ }^{1}$ Bonhoeffer, Letters and Papers from Prison, 178. ${ }^{2}$ Ibid. , 196.
} 
We are moving towards a completely religionless time; people as they are now simply cannot be religious any more. Even those who honestly describe themselves as 'religious' do not in the least act up to it, and so they presumably mean something quite different by 'religious'. . . The questions to be answered would surely be: What do a church, a community, a sermon, a liturgy, a Christian life mean in a religionless world? How do we speak of God without religion, i.e. without the temporally conditioned presuppositions of metaphysics, inwardness, and so on? How do we speak - . in a 'secular' way about 'God'? In what way are we 'religionless-secular' Christians, in what way are

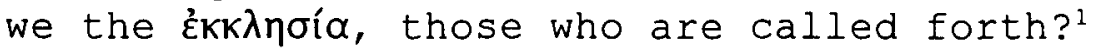

Bonhoeffer rejected the concept of religion that interprets God individualistically or metaphysically. God is neither exclusively within human beings nor totally beyond them.

Christ lived, suffered, and died for others. He was resurrected and, ever since, identifies Himself with the community of believers, called and formed by the Holy Spirit. According to Bonhoeffer, it is necessary to find a new role for Christianity in "a world come of age."2

To be Christian means to serve God, to participate in His sufferings in the world. The church exists "for others."3 A Christian is "a man for others."4

\footnotetext{
${ }^{1}$ Ibid. , 152, 153 .

${ }^{2}$ Ibid. , $178-182$.

${ }^{3}$ Ibid. , 208-211.

${ }^{4}$ Ibid. , 210.
} 
The thought of Bonhoeffer has raised many questions. This paradoxical theologian has exerted divergent influence. In any case, secular theologians gained inspiration from him for their theological thought.

\section{Secular Theology}

Secular theology rose and developed with the radicalization of the process of secularization of western society. After the second World War, traditional religion and orthodox Christian teachings were questioned by many and even abandoned by some.

A group of theologians was searching for a new approach to God and a new presentation of Christianity to the modern secular mind. Thus arose a radical movement among a group of Protestant theologians who took the expression used by the German philosopher Nietzsche "God is dead" and called their theology the "Death of God theology." These theologians believed that in a secular society it was necessary to preach secular theology. Theologians such as Bultmann, Tillich, and Bonhoeffer clearly influenced secular theology.

Three of the most significant theologians of secular theology were namely Thomas J. J. Altizer, J. A. T. Robison, and William Hamilton.

One of the most important exponents of this movement 
was Thomas J. J. Altizer, who accepted the element of "eternal recurrence" from Nietzsche's thought. ${ }^{1}$ He believed that all reality experiences a continuous destruction and re-creation through an irresistible, ongoing dialectic. Altizer applied this dialectic to God. He claimed the doctrine of the Incarnation, as Paul taught it in Phil 2:7-8 involved a self-emptying process of God.

Central to his view that God has experienced an ontological death is the assertion that He experienced that death in Christ. . . . The Deity accepted selfannihilation at the cross and in Christ set in motion an entirely new form of divine activity by which redemptive forces came into operation that hitherto were not known. . . Incarnation, then, becomes a progressive movement of Deity into temporal concreteness, a movement which may be said dialectical in that there may be both advancing and regressive movements. ${ }^{2}$

According to Altizer, the incarnation entailed a metamorphosis of God, in which He permanently divested Himself of all attributes such as transcendence, power, authority, etc. He suggested that was necessary to avoid the traditional Western terminology about God. He found the oriental concept of Nirvana useful.

Nirvana, as a concept, is regarded as the most effective instrument for delivering Western man from the narrow conceptualizing of the self and for

${ }^{1}$ Fuller, A History of Philosophy, 2:443, 444 .

${ }^{2}$ Harold B. Kuhn, "Secular Theology," in Tensions in Contemporary Theology, ed. Stanley N. Gundry and Alan F. Johnson (Chicago: Moody Press, 1976), 163. 
returning him to the new realization of the universally conceptualized All. ${ }^{1}$

In a world without God, according to Altizer, it is necessary to reject traditional Western concepts and terms for God and to accept Buddha as a primordial Christ, thus liberating the Western man from the claims of the historic Christ.

$$
\text { In 1963, J. A. T. Robinson (1919-1983), Anglican }
$$

theologian and bishop of Woolwich, published Honest to God, which caused a great sensation among Christians.

Robinson, building on P. Tillich, R. Bultmann, and D. Bonhoeffer, maintained that Christianity must no longer present religion as supernatural, mythologic, and transcendental.

The reference earlier to Bonhoeffer's theme of man come of age shows the close connection. Man is discovering that he no longer needs God or religion. According to this line of attack religion is a prop or a sop. It is not merely something incredible and superfluous: it is a dangerous illusion which can prevent men facing reality and shouldering responsibility. This lies at the heart of the Freudian critique of religion as the universal neurosis of the Marxist attack on it as 'the opium of the people'. God and the gods are the projection of men's fears, insecurities and longings. ${ }^{2}$

According to him, the image of God that traditional

Christian orthodoxy has given us is no longer credible, it

${ }^{1}$ Ibid., 165 .

${ }^{2}$ John A. T. Robinson, The New Reformation (Philadelphia: Westminster Press, 1965), 110. 
is culturally aged and out of date. Not being valid, this image must be eliminated and replaced by another.

Must Christianity be 'Mythological'? Undoubtedly it has been identified with it, and somewhere deep down in ourselves it still is. . . Behind such phrases as - . God came down from heaven . . lies a view of the world which portrays God as a person living in heaven, a God who is distinguished from the gods of the heaven by the fact that 'there is no god beside me'.1

The human being must no longer utilize spatial terminology about God. The scientifically oriented mentality of Western people has difficulty conceptualizing a God localized in a limited place. It is no longer possible to speak of God as a supernatural person. This abstract and metaphysical language conveys nothing to the people of today. Humans must seek God in the depths of their being.

It is not wholly clear what Robinson believes God to be. His view was close to a concept that he defined as panentheism, the belief that the Being of God includes and penetrates the whole universe, so that every part of it exists in him, but that his Being is more than, and is not exhausted by, the universe. Robinson advocated also the demytholization of the Incarnation. He reinterpreted the kenotic passage of Phil 2:5-11 to signify that Christ

${ }^{1}$ John A. T. Robinson, Honest to God (Philadelphia: Westminister Press, 1963), 32. 
emptied Himself not of his Godhead but of Himself. He disclosed and lays bare the ground of man's being as love. Finally, according to him, the function of worship is not to escape from this world into the other world, but to open oneself to the meeting of the christ. The function of worship is to make us more sensitive to others, to find in Christ the grace and power to be the reconciled and reconciling community. ${ }^{2}$

According to Hamilton, God died gradually. God's death occurred at Calvary in the death of the Incarnated God, again in the nineteenth century when faith collapsed, and in our time when humanity lost the sense of God's reality. God is no longer necessary for the solution of human problems. In our secular society it is no longer possible to speak of God in terms of fear, mystery, the supernatural, or to believe in a transcendent God.

Modern man must learn to live without God in a world in which only love gives meaning to human existence. Christian love is the unique value available to man in this present moment.

The death-of-God theologians insist that the language previously used to describe God is now meaningless.

${ }^{1} \mathrm{Cf}$. ibid., 75 .

${ }^{2} \mathrm{Cf}$. ibid., 87, 88 . 
Secularism with its characteristic way of thinking has thus also entered into the theological field.

\section{Christian Theology: Vehicle of Dualism}

The ontological and anthropological dualism of Christian theology with its dichotomies, such as body/mind, clergy/laity, sacred/profane, religious/secular, etc., and the consequent removal of the spiritual realm to a sphere far away from daily human life has contributed to the secularization of Western culture and have created many problems for the mission of Christianity. Christian Missionaries often preach the gospel to save "souls", and introduce science and technology in the schools and hospitals to help people find solutions to "material" problems. Many cultures do not make a sharp distinction between natural and supernatural.

Nothing has hindered the modern mission movement more than modern dualism that separates body from spirit, science from religion, and natural from supernatural. ${ }^{1}$

When secular people think and examine religious problems, they use the theological and philosophical concepts of Western thought. Many times they do not understand the biblical message until the true biblical message is clearly separated from the concepts that the

\footnotetext{
${ }^{1}$ Bruce Bradshaw, Bridging the Gap (Monrovia, CA: Marc, 1984), iii.
} 
Western mind has received from philosophers and theologians who have been influenced by Greek philosophy.

\section{Summary}

In this chapter we have seen how platonic dualism has led to the development of a series of dichotomies within Christianity, such as spirit/matter, soul/body, clergy/laity, etc. and consequently within the secular mind. We have seen also how the emancipation of the states, consequence of the Thirty Years' War, liberal Protestant theology, God's death theology, and other secular theologies, have contributed to the development of the process of secularization.

Finally, secular theology, consequence of the process of secularization, has showed how deeply secular thought is ingrained in the Western mind. 


\section{CHAPTER V}

SCIENTIFIC THEORIES THAT HAVE CONTRIBUTED TO THE FORMATION OF SECULAR INTELLECTUAL MAN

\section{Introduction}

The desire of finding an explanation to natural phenomena is deeply rooted in human nature. One should not be surprised that human beings have sought many times to give explanations to them.

Human beings know through generalizations. Individual experiences permit humans to select what is relevant from what is irrelevant. In general relevant factors are included in generalizations, while the irrelevant ones are excluded. Among the ancients there are many generalizations of natural phenomena, which are explanations of the phenomena.

As we have seen, 1 Greek philosophers were the first human beings to search for a rational explanation of reality. However, this was only the beginning. The subsequent development of science continued to influence the

${ }^{1}$ See p. 22 above. 
process of secularization.

In this chapter the most important scientific theories or discoveries, which have contributed to the formation of the process of secularization and consequently have influenced the western mind, are considered.

\section{The Geocentric Universe}

In astronomy Aristotle proposed a finite, spherical universe, with the earth at its center. The central region is made up of four elements: earth, air, fire, and water. Each of these four elements has a proper place according to its relative heaviness. The heavens move naturally and endlessly in a complex circular motion. They were made of a fifth, different element, called aether.

Later, Ptolemy, an Alexandrian astronomer of the second century A.D., like Aristotle, postulated a geocentric universe in which the earth was stationary and motionless at the center of several concentric, rotating spheres. These spheres bore the moon, Mercury, Venus, the sun, Mars, Jupiter, Saturn, and, finally, the so-called fixed stars.

In his physics Ptolomey was a follower of Aristotle. - . Everything below the moon is made of earth, water, air, and fire. . . . The celestial bodies, however, are made of a fifth element, the ether, which is pure and simple and therefore incapable of change. ${ }^{1}$

'James Evans, "Ptolemy," in Cosmology, ed. Norriss S. Hetherington (New York: Garland Publishing, 1993), 127. 
Ptolemy claimed that his system revealed the real structure of physical reality. His vision of the universe dominated Western thought until the times of Copernicus and Galileo.

\section{The Heliocentric System of Copernicus}

Copernicus Nicolaus (1473-1543), a polish astronomer, formulated a new astronomical theory according to which the sun is at rest near the center of the universe, and the earth revolves annually around the sun. According to Copernicus, his sun-centered system gave an explication to all astronomical observations and was more than a mathematical model inasmuch as it corresponded to reality. According to his theory, neither the earth nor human beings were at the center of the universe.

Later Galileo (1564-1642), an Italian physicist and astronomer, accepted and defended the Copernican theory. He, with the German astronomer Johannes Kepler, initiated the scientific revolution that flowered in the work of the English scientist, Sir Isaac Newton.

Galileo preferred the Copernican theory, according to which the earth revolves around the sun, because it supported his theory that the tides are based on the motion of the earth.

The great merit of Galileo was to construct a telescope 
for direct investigation of natural phenomena. Through this instrument Galileo observed mountains and craters on the moon, the four largest satellites of Jupiter, the phases of Venus, thus contradicting Ptolemaic astronomy and confirming his own preference for the Copernican system.

In 1616, Copernican books were subjected to censorship by edict, and the Jesuit cardinal Robert Bellarmine instructed Galileo that he must no longer hold or defend the concept that the earth moves.

In 1624 Galileo began to write a book that he wished to call Dialogue on the Tides in which he discussed the Ptolemaic and Copernican hypotheses in relation to the physics of tides. In 1630, the book was licensed for printing by Roman Catholic censors at Rome and was published in Florence in 1632 .

Later the Dialogue was ordered to be burned and Galileo was compelled to abjure it and sentenced to life imprisonment. This was later commuted to permanent house arrest.

\section{Nature Written in Mathematical Language}

According to Galileo, the Bible and nature were both God's books, but written in two different languages. The book of nature is written in mathematical language, and the 
Bible, God's revelation, in a language that common man can understand.

This metaphor of the two books, of which Galileo was fond, had significant consequences. For example, it provided an assurance that ultimately science and religion must be consistent, because an always truthful God is the author of both books. ${ }^{1}$

According to Galileo, in nature there are two classes of qualities: primary qualities, such as shape, size, number, position, and quantity of motion, which are objective properties of bodies; and secondary qualities such as colors, tastes, odors, and sounds, which exist only in the mind of the perceiving subject.

According to Galileo, the qualitative aspects of natural phenomena were irrelevant; he believed that only by quantifying the phenomena can they be studied by scientists.

With his final book, Discourses Concerning Two New Sciences, which was published at Leiden in 1638, Galileo presented the principles of mechanics. The book opened a road to Newiton, who, with his law of universal gravitation, linked Kepler's planetary laws with Galileo's mathematical physics.

Galileo's most valuable scientific contribution was his founding of physics on precise measurements rather than on

${ }^{1}$ Richard J. Blackwell, Galileo, Bellarmine, and the Bible (Notre Dame, IN: University of Notre Dame Press, 1991), 165, 166. 
formal logic. During all his life Galileo tried to free scientific inquiry from the restrictions of theological interferences.

\section{A Mechanistic Model of the Universe}

Later, Newton (1642-1727), a British scientist, completed the Copernican revolution by formulating the law of gravitation. According to him, gravity is a universal force that could simultaneously cause both the fall of stones to the Earth and the closed orbits of the planets around the sun.

Newton synthesized the mechanistic philosophy of Descartes, Kepler's laws of planetary motion, and Galileo's laws of terrestrial motion into one comprehensive theory.

Newton agreed with Galileo that only the primary qualities of natural phenomena ought to be the proper objects of the study of physics. Also, according to him, the essential object of scientific inquiry was the determination of the manifest qualities that may be measured by experiments.

He proposed a mechanistic model of the universe. This model challenged the traditional idea of God's providential hand in keeping stars, sun, and planets in their respective places. Newton's mechanistic vision led scientists to conceptualize the universe as an enormous, self-sufficient 
machine that did not require the intervention of God.

Newton definitely contributed to both tendencies, the understanding of the universe according to a mechanistic, mathematically ordered, material model and the modern comprehension of man as a rational, intelligent being.

\section{Scientific Discoveries and the New Worldview}

Between the fifteenth and seventeenth centuries, according to this new worldview, the universe was no longer considered to be a visible expression of supernatural realities but only and simply a material reality. The human being, confident in his own possibilities of knowing, became skeptical of orthodoxies and rebellious against any form of absolute authority.

Initially there was no clear distinction between astronomy and astrology, chemistry and alchemy. But later, with the new vision of the universe, the demarcation between scientific and esoteric teachings became clearer.

Classical vision of the universe was geocentric, finite, and hierarchical, with the heavens influencing human affairs according to celestial movements. Medieval people continued to hold almost the same classical vision. With the rise of the new science, the celestial bodies lost symbolic significance and their motion was considered to be 
a product of mechanistic laws. Nature was dissociated from supernatural causes and acquired a secular meaning. Astrology was no longer credible.

After Galileo and Newton, the planets were regarded as material bodies. Galileo, through his experiments, had established the laws of falling bodies and a new scientific method. He combined experimentation with measurements and mathematical formulations.

The application of the mathematical method was the consequence of the conceptions of the universe as governed by laws of causality.

The determinism of modern science is of a very different nature. It developed from the success of mathematical method in physics. If it was possible to construe physical laws as mathematical relations, if deductive methods turned out to be the instruments of precise predictions, there must be a mathematical order behind the apparent irregularity of experiences; there must be a causal order. . . . This physical determinism was a general outcome of Newtonian physics. It is intrinsically different from fate; it is blind, not planning. . . . But it is as strict and exceptionless as the determinism of fate. It makes the physical world comparable to a wound clock that goes automatically through its stages. ${ }^{1}$

The idea of a strict causal determination of natural phenomena was the product of modern times. For the Greek's, predetermination had a religious meaning: human affairs were governed by an unchangeable divine fate. Not even Jupiter,

\footnotetext{
${ }^{1}$ Reichenbach, The Rise of Scientific Philosophy, 106.
} 
the father of the gods, could change the destiny of human beings. But the determinism of modern science derived from the conviction that behind the apparent irregularity of natural phenomena there was a causal order, determined by the mathematical laws of nature, necessary and universal, which appeared to be an instrument of order and allowed precise predictions.

\section{Positivism}

The progress realized by science and the extraordinary confidence in human reason reached its logical conclusion with Positivism.

One of the early critics of Newton's philosophy of science was Berkeley (1685-1753), who sought to show that material substances do not exist. Accordingly, being coincides with the impact produced by the forces on the senses. Esse est percipi, "to be is to be perceived" is a formula used by Berkeley to express his thought.

Berkeley held that Newton was correct to distinguish his mathematical theories of refraction and gravitation from any hypotheses about the "real nature" of light and gravity. What distressed Berkeley was that Newton, under the guise of suggesting "queries," did talk about forces as if they were something more than terms in equations. ${ }^{1}$

Galileo, Descartes, and Newton had accepted the

${ }^{1}$ Losee, A Historical Introduction of the Philosophy of Science, 165 . 
distinction between primary and secondary qualities;

Berkeley denied that there are any primary qualities.

According to Galileo, Descartes, and Newton, extension, position, and motion were primary qualities; according to Berkeley, they are sensible qualities, perceived by sense experience.

It is meaningless to talk of absolute space. Space does not exist apart from human perception. Berkeley observed that whereas "forces" are useful mathematical fictions, "absolute space" is useless fiction and should be eliminated from physics.

According to Comte (1798-1857), a French philosopher, there are three stages in the intellectual history of human beings: the mythological, the metaphysical, the positivistic. The first represents a point of departure; the second, a period of transition; the third, a final stage, which involves rejection of all hypothetical construction of entities regarded as existing apart from the sensible universe. The empirical sciences are a reliable source of knowledge for the human mind, which progresses and learns to recognize as mere imagination those explications of reality that are not scientific.

Another critique, similar to that given by Berkeley of Newton's philosophy of science, was developed by Ernst Mach 
(1838-1916). He believed that scientific laws and theories are simply summaries of facts. According to Mach, science should restrict itself to the description of phenomena that can be perceived by the senses. He tried to free science from metaphysical concepts and helped to establish a scientific methodology that paved the way for the theory of relativity.

\section{New Scientific Discoveries in Physics and Natural sciences}

In the nineteenth century, classical physics reached the culmination of its possibilities of development. Scientists elaborated the definitive formulation of Newton's mechanics, discovered the first and second principles of thermodynamics, and developed theories of electromagnetism and static mechanics based on the classical conception of causality. Certain problems associated with classical physics, however, seemed unsolvable.

Theories of relativity, quantum physics, of the wavenature of matter, and the uncertainty principle, provided a solution to some problems of classical physics. At the same time they contributed toward a new vision of physical reality.

In the natural sciences Jean Baptiste Pierre Antoine de Monet, better known as the Chevalier de Lamarck (1744-1829), elaborated the theory of the inherence of acquired 
characteristics. According to him, living beings constantly change under the influence of the environment and develop special properties that, accumulated after a long period of time, establish new species.

Later, Charles Darwin (1809-1882), an English scientist, proposed a different idea of evolution. He was opposed to the idea that species are immutable and proposed that all species, including human beings, had evolved from a primitive cell. According to him, the evolution of living species is a fact clearly established by biological evidence. Two are the factors that interact in the process of evolution: the survival of the stronger and more qualified in the struggle of life, and natural selection, by which the stronger elements lead to the establishment of a new species.

Formerly, with the heliocentric astronomical system, the Earth, and consequently the human being, was no longer regarded as being at the center of the universe. Now with Darwin's biological evolution, human beings became simple animals as a result of a fortuitous evolutionary process.

Nature itself, not God. . . was the origin of nature's permutations. Natural selection and chance, not Aristotle's teleological forms or the Bible's purposeful Creation, governed the processes of life. The early modern concept of an impersonal deistic Creator who had initiated and left to itself a fully formed and eternally ordered world. . now receded 
in the face of an evolutionary theory. . . Humans, animals, plants, organisms, rocks and mountains, planets and stars, galaxies, the entire universe could now be understood as the evolutionary outcome of entirely natural processes. ${ }^{1}$

With Darwin, any remaining special spiritual status of the human being was erased. He is no longer God's creature, but only a fortuitous result of a natural selection, an animal whose consciousness arose accidentally during the evolutionary process.

According to the new vision, the Earth and humans are an insignificant part of an immense universe and their temporary existence does not have any meaning.

\section{Neo-positivism}

The encounter between the new science and philosophy produced a new philosophical movement, called neopositivism.

Ludwig Wittgenstein (1889-1951) is considered the father of neo-positivism. He distinguished between what can be said and what cannot.

According to him, there are three classes of expressions: those with sense, tautologies, and contradictions. Tautologies and contradictions tell nothing about the world. "The world is determined by facts.

${ }^{1}$ Tarnas, The Passion of the Western Mind, 289. 
The facts in logical space are the world. We picture facts. A picture is a model of reality. Tautologies and contradictions are not pictures of reality. They do not represent any possible situations."1

Wittgenstein affirmed that only expressions that are pictures are propositions with sense. They are true or false, depending on whether they represent natural reality correctly or incorrectly.

According to the positivists, the only possibility that we have of establishing the truth of a sentence is to "verify" it experimentally. All propositions must be verifiable. Only scientific assertions can be warranted by experiments. Thus, only in science is it possible to have true knowledge. Metaphysical sentences have no meaning, because they cannot be experimentally verified; thus, the sentence "God exists" is neither true nor false; it is simply without meaning.

The elimination of metaphysics is accomplished on the basis of the claim that all metaphysical assertions are non-empirical. . . . The new positivistic opposition to metaphysics . . . must be distinguished from the traditional positivism. . . . This distinction is immediately evident, for instance, in the case of the metaphysical statement in non-animistic theology "There is a God," where the term God lacks ostensive reference in that it is not defined in terms of observable phenomena. By the theist the statement is considered

${ }^{1} \mathrm{Cf}$. W. T. Jones, The Twentieth Century to Wittgenstein and Sarte (San Diego: Harcourt Brace Jovanovich, 1975), 205207 . 
to be a genuine meaningful proposition and true. For the atheist it is a genuine proposition and false. For the agnostic it is a genuine proposition the truth value of which cannot be determined. For the Logical Positivist it is neither true nor false and is not, therefore, a genuine proposition; it is meaningless. ${ }^{1}$

The criterion of verifiability, according to which metaphysical sentences do not have a meaning if they cannot be experimentally verified, has been widely criticized.

Among the members of the Vienna Circle a dispute arose over the meaning of the sentence "possibility of verification."

The verifiability criterion soon was recognized to be overly restrictive, however. It excludes universal statements such as 'all sodium samples react with chlorine' and 'all negatively charged bodies attract positively charged bodies.' No finite set of observation reports could establish these statements as true. The most that can be established is that no exceptions have been observed to date. Recognition that both the verifiability criterion and the falsifiability criterion exclude statements which ought to qualify as empirically significant, led philosophers to seek alternative approaches to the problem of demarcation. ${ }^{2}$

Carnap (1891-1970) chose a new approach--that of the construction of an "empirical language." According to him, scientific laws and theories must be translated into an empiricist language constructed for such purposes. Obviously, it is necessary to make a distinction between (1) real-object statements, i.e. the rose is red, a

${ }^{1}$ Fuller, A History of Philosophy, 595, 597, 598.

${ }^{2}$ Losee, A Historical Introduction to the Philosophy of Science, 185 . 
genuine factual sentence, which is verifiable in experience; (2) pseudo-object statements, i.e., the rose is a thing, a metaphysical sentence, which introduces a non-experiential element as thing; (3) syntactical sentence, i.e., the word rose is a thing-word, a sentence that is meaningful on the level of language. ${ }^{1}$

According to him, the statement God exists has no meaning, because the word God does not make sense. But the word God has always had a deep meaning for human beings. The word God was not introduced in the human language by philosophers or other scholars. When philosophy arose in the sixth century (B.C.) the word God already existed. The concept of, and the word, God have always existed and belong to the cultural heritage of peoples of the whole earth and all times. Carnap himself acknowledged that the criteria proposed were too narrow and tried to revise the translatability criterion.

Later, Popper (1902-), an Austrian-born British philosopher of science, criticized certain assertions of neo-positivism. According to him, scientists can never know whether any universal theory is true. In this sense his scepticism is deep, but he thinks that it is possible to base an account of scientific rationality on the negative

\footnotetext{
${ }^{1} \mathrm{Cf}$. Fuller, The History of Philosophy, 600 .
} 
activity of attempting to disprove theories. The empirical disproof of a theory is conclusive, while all evidence in favor of a theory is inconclusive.

Popper proposed the criterion of falsifiability. For scientific validity, Popper emphasized that scientific theories are hypotheses from which can be deduced statements testable by observation.

If the appropriate experimental observations falsify these statements, the hypothesis is refuted. If a hypothesis survives efforts to falsify it, it may be tentatively accepted. No scientific theory, however, can be conclusively established.

Popper viewed the history of science as a sequence of conjectures, refutations, revised conjectures, and additional refutations. And he concluded that the distinguishing characteristic of scientific

interpretations is their "susceptibility to revision." - . According to Popper, to insist that scientific interpretations continually be exposed to the possibility of falsification is to promote scientific progress. ${ }^{1}$

With Galileo and Newton, mathematics emerged as the proper language of nature and the universe became a great machine, a unique reality, ruled by precise physical laws. Today with quantum mechanics, relativity theory, and the uncertainty principle, the empirical, concrete physical

${ }^{1}$ Losee, A Historical Introduction to the Philosophy of Science, 192 . 
reality has been transformed into an empty space inhabited by ghost particles. With neo-positivistic logic the empirical sciences have become a continual sequence of conjectures and refutations.

\section{Positive and Negative Effects Produced by Technology}

In our century, science and technology have produced many benefits for humankind. New medicines, better medical attention, and improved sanitation have increased the average life of human beings in industrial nations. Machines have released men and women from much of the heavy work that in previous ages absorbed most of people's time and energy. Increases in productivity have led to shorter working hours and longer free time that humans dedicate to the arts, social service, sports, etc. The news media offer the possibility of instant worldwide communication; new forms of transportation provide rapid travel to distant cities.

Nevertheless, the development of science and technology has also created a new mentality. The mass media tend to produce a uniform culture, and to stereotype interactions among people. The industrialization of Western society has produced the bureaucratization and urbanization of modern times. 
The growth of urban living has contributed to an increase of pluralization in the private sphere also, making the task of integration increasingly difficult. According to Berger, this situation leads more and more often to experiences of frustration, to permanent crises of identity for individual, and finally

'homelessness' in the social world. Nor can religion offer a way out of this situation, because it is itself threatened by pluralization, namely by the plurality of religious or ideological systems of meaning which the individual encounters and the truth-claims of which reciprocally relativize themselves for him. For this reason alone the religious tradition has largely lost its plausibility. ${ }^{1}$

Science and technology have spread Western culture around the globe with many dichotomies: spirit-nature; mindbody; reason-emotivity; objectivity-subjectivity; domination-submission, etc., and a mentality of selfishness, a spasmodic search for economic wealth, and at the same time an indifference toward the problems of others and a disinterest toward the problems of the environment.

Technology is an uncontrollable force that can be used for the good or evil of society. Industry has also produced powerful armaments, which caused the death of millions and enormous material damage during the two world wars. After the Second World War, many political myths collapsed.

Religion was criticized, for many people asked: How is it possible that Christian nations caused all these destructions? This criticism has negatively influenced many

${ }^{1}$ Pannenberg, Christianity in a Secularized World (New York: Crossroad, 1989), 30 . 
intellectual people toward religion.

\section{Some Final Considerations}

For the Ancients, nature was a divine organism consisting of celestial bodies endowed with life extending in space and moving in time by a divine Logos. The whole polytheistic vision of the cosmos disappeared with the patristic era and Middle Ages.

In this chapter we have seen how the scientific theories of Galileo, Newton, and others reduced the observation of nature to the quantitative aspect. But quantitative analysis is incapable of perceiving the qualitative aspect of nature and human values. The mathematical laws of nature entail necessarily the relativity of all things that cannot be measured quantitatively.

With Copernicus, Galileo, Newton, and Kant nature was regarded as a set of physical phenomena, which cannot be understood metaphysically, but only experimentally. In addition, the things in themselves, God and the "I," cannot be known experimentally.

The excessive reactions of the Church, and the false antinomy science-Christendom, transformed secularization into atheistic secularism.

The idea of God gradually disappeared. First, God was 
identified with nature (according to a form of pantheism). Later, He was separated from the world and moved far away from it (according to a form of deism). Lastly He disappeared. The philosophies of science contributed to the formation of the secular Western mind.

In this chapter we have also seen how the development of quantitative scientific laws and biological macroevolution have produced a materialistic secular vision of nature. With modern science considerations based on metaphysical, aesthetical, ethical principles were restricted to the private sphere of values.

Science replaced religion as the preeminent intellectual authority. Human reason and empirical observation became the principal means for comprehending the universe.

Conceptions involving transcendent realities were regarded as beyond human comprehension, fundamentally distinct from public, objective, scientific knowledge of a material world.

Religion was increasingly considered an emotional superstition necessary for morality but irrelevant. With new science the Earth and the sun became simple material bodies among countless other bodies moving in a void. 
112

Science presented a mechanistic vision of a material universe. Ecstasies, encounters with devils, and other religious supernatural affairs were regarded as effects of charlatanry or even of madness. God became an unnecessary hypothesis. 
CHAPTER V́I

AN INTELLECTUAL PROFILE OF SECULAR PEOPLE

\section{Introduction}

It is very difficult to outline a profile of secular people. They belong to many social and cultural classes. There are managers and employees, industrialists and workers, rich and poor, intellectual and uneducated, etc. All these classes have their own particular characteristics, which differentiate one from another.

The purpose of this dissertation is to develop an intellectual approach to communicate the biblical message to secular people. Therefore, in outlining a profile of secular people, preference is given to the religious and intellectual aspects of their mentality.

Every human being has a world view that provides a particular approach to understanding God and the world. It is important, for those who wish to communicate the biblical message to secular people, to identify their particular world view, that is to say their basic assumptions about the origin and purpose of human life. 
114

The most frequent characteristics of the thought of secular people are considered according to their relationship with disciplines such as philosophy, ethics, theology, science. At the end, some other characteristics are considered.

\section{Secularism Is Inadequate for the Life of Human Beings}

For the Ancients, nature was a divine organism consisting of celestial bodies endowed with life extending in space and moving in time by a divine Logos. The whole polytheistic vision of the cosmos disappeared with the patristic era and Middle Ages and was replaced by the angelology and demonology such as one can see reflected in the paintings and other manifestations of medieval culture.

As we have seen, ${ }^{1}$ later, with Copernicus, Galileo, Newton, and Kant, nature became a set of physical phenomena, which can be no longer understood metaphysically, but only experimentally. In addition, things in themselves, God and the "I," cannot be known experimentally.

The idea of God gradually disappeared. First, God was identified with nature (according to a form of pantheism). Afterward, He was separated from the world and moved far away from it (according to a form of deism). Finally, as we

${ }^{1}$ See pp. 93-97 above. 
have seen, ${ }^{1}$ with the critiques of Feuerbach, Marx, and Freud, He disappeared. All these philosophies, and others that have been examined, have produced the secular Western mind.

The excessive reactions of the Church contributed to transform secularization into atheistic secularism.

For human beings, secularism is philosophically and religiously inadequate. One of the inadequacies of secularism is that it considers human beings as capable of evaluating themselves. The Protagorean principle, "man is the measure of all things," is part of secular philosophy. If a human being compares himself with other earth creatures, he clearly sees he is the highest of them. However, secular people are aware of their limitations, and their mistakes.

Secular people need an orientation toward which to direct their lives, a model on whom they can structure their life, and power that allows them to change and improve their own life. Contemporary society gives them neither an orientation nor an aid. Frustration and hopelessness are the consequence. The help that they can receive by psychological counselors is completely insufficient.

But people need to be oriented on that which gives

${ }^{1}$ See pp. 76-79 above. 
binding meaning. Erich Fromm has spoken of the need for a referential framework to provide orientation on the world. . . Without such an orientation that is binding on the individual everything can become a matter of indifference. And in that case hopelessness and feelings of alienation spread under cover of succumbing to the pressures of the consumer society. ${ }^{1}$

Secular people are living in a world where ethics and philosophies of life are erected on the pillars of revisionism and relativism, which have led to pluralism. However, they are not satisfied with pluralism.

The psychoanalytical interpretation of the moral norms as an expression of the demands of society on individuals does not help human beings to accept them.

An end to attaching any binding character to moral norms has certainly been favored by psychoanalytical interpretation which sees them as an expression of the demands of society on individuals, which are internalized by them. In that case morality appears as an expression of social repression. The opposition of individual freedom to all institutional rules and claims on the individual can also be directed against the institution of the family. Where the context of marriage and family is destroyed, the individual is threatened with solitude, especially at a later stage of life.?

The ideals that secular society can offer to people are limited and lack a deep motivation. Secular people need a larger vision of reality and a clear orientation in their lives. The lack of meaning can lead to alienation and

${ }^{1}$ Pannenberg, Christianity in a Secularized World, 32 , 33.

${ }^{2}$ Ibid. $, 36,37$. 
sometimes neurotic deviations.

The individual in his or her struggle toward orientation and identity is hardest hit by the loss of a meaningful focus of commitment, a loss which results from the secularization of culture. . . . In many cases the loss of a meaningful focus of commitment does not just lead to the experience of homelessness and alienation in a culture but also to neurotic deviations. ${ }^{1}$

Secular people realize that relationships with other human beings are not satisfactory. They need a true fellowship in a community of free human beings, who love each other as true brothers.

\section{The Philosophical Thought of Secular People}

Secular people are natural products of the type of education in the schools of the Western Hemisphere. Secular thinking is typical of Western culture.

As we have seen, ${ }^{2}$ Greek dualism has influenced the Western mind. Secular people accept and use the typical Western dichotomies of rational-irrational, naturalsupernatural, etc., in order to organize their experience. According to them, the physical natural world is the most important.

Secular people refuse all forms of dogmatism. As we

${ }^{1}$ Ibid., 37.

${ }^{2}$ See pp. 23-24, 65-69, 89-90 above. 
have seen, ${ }^{1}$ with the Renaissance a new sense of intellectual capability spread throughout Europe. In spite of the sense of angst that existentialism brings to the consciousness of humans, ${ }^{2}$ many secular people have faith that rational human effort can overcome obstacles and find solutions to the problems of our world.

According to them, only the physical world is knowable and science is the proper means of knowing it. As we have seen, ${ }^{3}$ the benefits produced by science and technology, have created a new mentality in Western people.

Some secular people believe that science, technology, and education are the three factors through which it is possible to improve the world. Fatalism is generally repudiated.

Some secular people think that only natural things are important. They are not concerned with the supernatural. If matter generated life and the human mind through a long evolutionary process, then mind is a purely natural phenomenon, an attribute of the brain. Only the physical universe is real; God, angels, and other forms of the supernatural are mere fruits of human imagination. The

${ }^{1}$ See pp. 34-36 above.

${ }^{2}$ See pp. 46-47 above.

${ }^{3}$ See pp. 108-110 above. 
physical universe came to existence by accident. ${ }^{1}$ Human beings, using their intelligence and capacities and cooperating liberally with one another, can build a world of peace and happiness.

\section{The Ethical Relativism of Secular People}

Refusal of the supernatural does not necessarily make secular people immoral; they still find it necessary to provide a rational justification for their acts. The human being must act rationally. Ethics and politics must be rationalized. Secular people, however, combat formalism and authoritarianism in ethics. They reject the puritanical prejudice against pleasure and desire. While it is true that uncontrolled human desires are a prime cause of evil, it is equally true that human desires directed by reason toward socially useful goals are a prime foundation of good. Human beings have profound emotional and physical wants and needs that must be satisfied. A suppression of normal desires may result in their discharge in surreptitious and abnormal ways.

According to traditional religious belief, God is the source and enforcer of ethical systems. For secular people, who do not believe in God, moral values do not have a

${ }^{1}$ See p. 103 above. 
transcendental and absolute foundation; they derive from human experience. Human beings adjust their ethical standards according to their own judgment, and human reason determines what is right or wrong in the context of ethical relativism.

Traditionally, ethical values have been rooted in religious convictions. This position has been challenged in recent years by secular humanists. . . Paul Kurtz, for many years editor of The Humanist magazine, writes: While life has no meaning per se, it does provide us with opportunities to enjoy, discover, and create. The great challenge for the humanist is to lead the good life on his terms and to take destiny in his own hands. Of the many values that the humanist defends, individual freedom is basic: the right of the individual. . . to develop his own conscience, and to lead his own life without undue interference from others. . . The basic assumption of the new morality is the conviction that the good life is achieved when we realize human potential. This means that we ought to reject all those creeds and dogmas that impede human fulfillment or impose external authoritarian rules on human beings. ${ }^{1}$

As we have seen ${ }^{2}$ with Nominalism, Empiricism, and Postmodernism, human certainties have collapsed. Secular people reject the existence of absolute values. They think that every society in every time must choose its own values. It is not necessary to anchor them to any eternal and supernatural ground. All ethics are thus relative to the interpretations that human beings give in a particular

${ }^{1}$ Eddie Gibbs, In Name Only (Tunbridge Wells, Kent, England: A BridgePoint Book, 1994), 174, 175.

${ }^{2}$ See pp. 37-40, 54-60 above. 
historical situation. Moral judgments, like other human judgments; are temporary, partial, and changeable. Persons orient the life toward their own particular values.

Some secular people think that humans are responsible for their actions, because they can choose freely. For others, on the contrary, humans are not free, but they are manipulated in many ways by the social environment.

\section{The Religious Thought of Secular People}

Secular people want be free from religious control.

They limit their horizon to this world. H. Cox wrote:

What is secularization? The Dutch theologian C.A. Van Peursen says it is the deliverance of man "first from religious and then from metaphysical control over his reason and his language." It is loosing of the world from religious and quasi-religious understandings of itself. . . the breaking of all supernatural myths and sacred symbols. ${ }^{1}$

Secular people feel like adults, or, as Bonhoeffer said, people come of age, ${ }^{2}$ and want to affirm fully their autonomy in knowledge of, and dominion over, the world. They want to resolve the important questions of their lives by themselves.

Anthropologists characterize secular people as persons indifferent to religion. Very few secular people believe

${ }^{1}$ Cox, The Secular City, $1,2$.

${ }^{2}$ See pp. 81-84 above. 
that prayer and the observances of church rules really affect the course of human events. Generally, public figures participate in public worship for reasons of expediency. Only a limited minority believes in God's judgment.

Sometimes feelings of guilt are present, but the sense of wrongdoing is rare. Secular people feel the need of release from guilt, but they do not find forgiveness for their faults in God, because they have an inadequate image of God. G. Hunter observed:

Schuller also observes that the model of God in many secular minds reinforces their insecurity. Some people image God as the "Grim Reaper" who threatens people's lives, or the Santa Claus who gives presents based upon our goodness, or the cop who watches for us to do something wrong, or the Duplicitous Politician who uses people and manipulates nations. ${ }^{1}$

Not all secular people are atheists. Many of them believe in God even if in an abstract and vague manner. Secular people refuse religion, but not necessarily God. They refuse the religious and philosophical forms in which God is presented. They do not accept the way in which some religious people present God. Often God is presented as a Monarch circumscribed to a particular spatial location. The pagan gods are regarded as human projections, supposedly

${ }^{1}$ George G. Hunter III, How to Reach Secular People (Nashville, TN: Abingdon Press, 1992), 50. 
with feelings much like our own. They protected all kinds of people, including thieves and prostitutes. They asked every kind of sacrifice from humans, also that of their own sons.

Christians also sometimes present God as a severe Monarch always ready to send storms and lightnings against those who dare to oppose His will. They also reject the abstract, ultramundane, absolute, metaphysical way in which philosophers and some modern theologians present God. According to Cox,

Two motifs in particular characterize the style of the secular city. We call them pragmatism and profanity. - . By profanity we refer to secular man's wholly terrestrial horizon, the disappearance of any supramundane reality defining his life. Pro-fane means literally "outside the temple"-- thus "having to do with this world." By calling him profane, we do not suggest that secular man is sacrilegious, but that he is unreligious. He views the world not in terms of some other world but in terms of itself. ${ }^{1}$

The story of Jesus' life still lives in their hearts.

They do not keep His commandments, but still call Him Master and Lord. Many secular people have a negative image of the Church. They criticize its formalism, the empty liturgy, the superficial preaching that speaks to minds but does not warm their hearts, and the abstract theology completely separated from human problems.

${ }^{1}$ Cox, The secular City, 52 . 
Historical, and literary criticism have furnished radically different versions of historic biblical events and personages. Scientists are always ready to give a natural scientific explanation to the events that have a supernatural explanation. When that is not possible, they consider the narrative of a historical event as a mythical tale. For them, inner vision and religious experiences are illusions. There is a sharp differentiation between the natural and supernatural worlds.

What was once ascribed to God can be explained in terms of natural cause and effect. . . As God is more and more removed from everyday life, people... increasingly live as though He did not matter. . . To the secular person, reality is what the five senses can perceive: what we can see, hear, taste, smell, and touch. That is reality. ${ }^{\text {I }}$

Secular people think that the natural world can be studied by the senses and the sciences, but they confine religious experiences that cannot be tested empirically to the imaginary, fancy world. Religion is emotion, feeling, poetry; ${ }^{2}$ science is knowledge, reasoning, reality.

We believe not only that the world is real, but also that it is orderly. We believe that with careful study we can understand why things happen and remedy whatever goes wrong. One basic way we analyze things is through science. We use it to break down the world into neat

Jon Paulien, Present Truth in the Real World (Oshawa, Ontario, Canada: Pacific Press Publishing Association, 1993), 55 .

${ }^{2}$ See pp. 110-112 above. 
categories and discover causes and consequences. We use that knowledge to control the world around us. When problems arise, we assume they can be solved if we have enough time and money. ${ }^{1}$

Secular people feel indifference to all kinds of religion. They believe they have surpassed that stage. Generally, they have a vague idea of God and may go to church, but deep down consider religion to be little more than superstition.

In the Greek world view . . the gods (theoi) are part of a supernatural realm inhabited by spirits of many kinds. The natural world, on the other hand, includes humans, animals, plants, and matter. As the West adopted this Greek world view, Western Christians absorbed its implicit meanings into their theologies. The result is a two-tier universe in which we use religion to describe supernatural realities and a secularized science to explain the natural order. ${ }^{2}$

According to them, many times in the past the Church was opposed to scientific progress and even today supports scientifically incorrect ideas. ${ }^{3}$ They do not appreciate religion because religious people many times despise science. Nor do they understand many windy, vague, banal religious sermons, because their mind is accustomed to logical, rational, scientific reasoning.

Secular people receive little religious information 117 .

${ }^{1}$ Hiebert, Anthropological Insights for Missionaries,

${ }^{2}$ Ibid., 158.

${ }^{3}$ See p. 111 above. 
from the mass media and the information received is often incorrect.

When religion makes an appearance in the public domain, it does so in the trivialized form of ceremonial religion or the vacuous form of civil religion. . . . In the popular press prominent publicity is given to moral scandals among church leaders, bizarre cultrelated incidents. Very little time is allocated in TV programming to discussing religious issues or reporting religious news. ${ }^{1}$

According to secular people, institutionalized religion destroys the freedom of human beings, ${ }^{2}$ presenting and imposing upon them a "public and dogmatic truth" without regard for human intelligence. Sometimes religion may traumatize humans and exercise psychological coercion, hindering people from the possibility of choosing according to their own convictions. They know that a system of beliefs is necessary to the survival of our society, but they wonder if the system of dogmas of the organized Church is compatible with contemporary secular knowledge.

They think themselves mature and are not ready to accept religious ideas without previous examination. Secular people fear the manipulation of their lives. They do not like any kind of religious coercion or psychological pressure. Generally they prefer meetings in which they are

${ }^{1}$ Gibbs, In Name OnIy, 179, 180.

${ }^{2}$ See pp. 50-51 above. 
allowed considerable freedom of expression. They want to feel free to accept or reject, to choose in what way they drive their lives.

Traditionally, the Church has relied on authoritative preaching to reach the unchurched masses, but most secular people experience such preaching as authoritarian preaching. It turns them off, or they are merely amused by the "great pulpit oratory" that many church people still love. ${ }^{1}$

The biblical knowledge of secular people is superficial. They know very little of the Bible, only a few stories and some doctrines of the church, but very little of the biblical message itself. What they know is generally superficial and often incorrect.

The reality is that secular people are almost totally insulated from Christianity. They don't read their Bibles or listen to sermons. They don't read tracts that someone may press into their hands. . . . They don't watch Christian television. ${ }^{2}$

They want to find their solution to their existential problems. They know they have only a limited vision of the universe; they are searching for a clearer understanding of reality around them. Generally they are interested only in real life before death. They are "life oriented." They seek meaning and purpose in this life and want to make their contribution while they live.

\footnotetext{
${ }^{1}$ Hunter, How to Reach Secular People, 57.

${ }^{2}$ Paulien, present Truth in the Real World, 41,42 .
} 


\section{What Secular People Think about Science and Technology}

Secular people admire the achievements of science and technology. The victories over sickness, the conquering of space, the journeys to the moon, and other achievements have created the confidence they have in science and technology. Sometimes they do not consider the negative effects caused by science and technology. Technological institutes, research laboratories, and industrial complexes spread scientific and technological knowledge in our industrial society, but many times this knowledge is used for unworthy ends.

In today's world most people make decisions and solve problems on the basis of science and the scientific method. . . The scientific way of reasoning affects everything we do and everything we believe. But because science cannot deal with the supernatural - . it has a natural bias toward explaining what happens in life as though God either doesn't exist or is uninvolved in the natural processes of life. ${ }^{1}$

It is very difficult for the scientific secular mind to accept religious language, even the language of the Bible. Secular people have difficulty understanding old language, also that of biblical writers. They also find it hard to accept a theology which reflects out-of-date philosophical or scientific theories.

With the theory of macroevolution many people no longer

${ }^{1}$ Ibid., 53, 54 . 
believe in divine creation. Many think that the universe, life, and the human mind are products of an evolutionary process and not a result of an act of love of the Creator God.

Secular people learn from public educational institutions that billions of years ago the universe came into existence from a fortuitous explosion of an enormous primeval atom. A speck of life came into existence by a series of accidental combinations of chemicals and energy. The first cell evolved into simple and then more complex species of plants, animals, and finally human beings.

Secular people, who believe in biological macroevolution and consider the narrative of the first chapter of Genesis a mythical tale, have serious problems in receiving the biblical message.

\section{Other Characteristics of Secular People Power, Prestige, and Pleasure}

Natural sciences have brought to modern capitalistic society the belief that the fundamental principles of animal life, and consequently human life, are the struggle for existence and the survival of the fittest. ${ }^{1}$

Technology in turn has brought unprecedented economic growth to industrial society. Possession of many gadgets,

${ }^{1}$ See pp. 102-103 above. 
predominance over others, and economical prosperity are marks of success. Happiness, prosperity, and well-being are measured by the quantity of income that a person reaches. However, economic growth of our industrial society coupled with a materialistic vision of reality certainly do not provide solutions to the deeper problems of human life. At the same time, absence of a faith in God, the impersonality of social organization in big cities, the lack of attention to human problems in our industrial society, and excessive individualism all make people feel adrift in a life that, for many, is meaningless.

In Western capitalistic society the pursuit of power, prestige, and pleasure is disguised as good works and moral actions. According to many people, the contemplative religious life is regarded as idleness. Comfort and economic possessions are worthy goals of their lives. The quantity of goods that people have provides a measure of their status and success and is a symbol of power and prestige.

Given our dualism between spiritual and material realities and our growing emphasis since the sixteenth century on the material world and the sciences, it should not surprise us that we North Americans tend to judge humans by what they own. We measure achievement and success primarily by the quantity of material goods a person possesses. Moreover, we tend to equate happiness more with material wealth and physical prosperity than with intellectual or spiritual gains. Condon and Yousef write, "'The pursuit of happiness' 
means, for many Americans, the opportunity to secure property and material comforts."

Secular people assume that all men and women have inalienable rights to life, liberty, and the pursuit of happiness. All individuals have their worth. Individualism leads to an idealization of freedom. All persons have right to their privacy. According to Cox, the secular person is "a pragmatic technopolitan," a citizen of the technopolis, only interested in whatever works and produces good results in this world. Two motifs characterize the style of the technopolis: pragmatism and profanity.

Cox writes:

He disciplines himself to give up certain things. - . . Life for him is a set of problems, not an unfathomable mystery. He brackets off the things that cannot be dealt with and deals with those that can. He wastes little time thinking about "ultimate" or "religious" questions. And he can live with highly provisional solutions. He sees the world not so much as an awesome enigma evoking a sense of hushed reverence, but as a series of complex and interrelated projects requiring the application of competence. He rarely ponders what we usually call religious questions because he feels he can handle this world adequately without them. ${ }^{2}$

Secular people are little interested in that which lies beyond the application of human energy and intelligence. Human life for them is a set of problems to be gradually

\footnotetext{
${ }^{1}$ Hiebert, Anthropological Insights for Missionaries, 115.

${ }^{2}$ Cox, The Secular City, 55 .
} 
resolved. Human beings must be aggressive if they want success in this life: Secular people do not want to be passive automatons, anonymous atoms of the social molecule. They are conscious of the diversity of every person. Sometimes they know they need to change their nature and realize the difficulty of changing human instincts.

But when human beings have learned to fly, they have not eliminated the force of gravity. With the help of God it is possible to give another direction to the instincts and forces that dominate human nature, avoiding conflicts and frustrations. Then God will fill the existential emptiness in every human being, something that material plenty cannot do.

\section{The Human Search for Meaning}

In every human being there is a longing for meaning. People seek to give a sense to things, to life, and to its multiple aspects. Secular people also inquire in themselves, around themselves, and in the objective reality outside of themselves for the real meaning of their lives. They want to know the truth about birth and death, the line of time that joins one with another, and lifetime experiences. They need to know their own value, the worth of their intelligence, their love, and their efforts. There is in every human being the desire to know. 
Contrary to what some people think, there is a tension that goes through all human life. It is impossible to believe that the tensions generated by this desire are the momentary result of the action of external historical-cultural factors. They are produced by the deeper part of human nature. Nothing can eliminate them unless they are suppressed in the human consciousness.

Obviously this desire for meaning, innate in every human being, exists also in secular people. They feel that science and material wealth cannot satisfy it. They seek to find a way of filling the existential emptiness that is within them. Even if their degree of religion is not high, the desire for meaning and the sense of alienation that are present in secular people create in them a need for religion.

The status of religion is not particularly high in many people's awareness and practices. But that does not mean that the religious theme is disappearing from human life. It is being repressed from consciousness, but it is present as the need to give meaning to life and as a sense of alienation in the secular world-indeed this need and alienation are very intensely present, although it is often not recognized that what is missing here is in fact religion. ${ }^{1}$

On the other hand, religion, as it is presented to secular people, does not satisfy their desire for meaning. If the communicators want the biblical message to be the

${ }^{1}$ Pannenberg, Christianity in a Secularized World, 44. 
answer to these existential problems, they must present the biblical message in a modern and rational language.

\section{Summary of Part One}

In Chapter 2 the terms such as secular, secularization, and secularism, have been considered and a definition of each one has been given. In Chapters 3, 4, and 5 the process of secularization has been delineated. In Chapter 6 a profile of secular people has been outlined.

A precise clarification of the meanings of terms such as secular, secularization, and secularism; a careful reconstruction of the process of secularization; and a detailed profile of secular people have certainly helped us to clarify the mentality and culture of secular people. Now it is possible to outline the methods for a correct presentation of the biblical message to secular people. 
HOW TO COMMUNICATE AND PRESENT

THE BIBLICAL MESSAGE 


\section{CHAPTER VII}

PAUL'S METHODS OF REACHING INTELLECTUAL PEOPLE

\section{Introduction}

The Apostle Paul had all the characteristics needed by a person who wanted to preach the biblical message to the "intellectual people" of his time.

Paul, as a Jewish scribe, knew the biblical message perfectly well and, as a Jew of the Diaspora, also knew the Greek language and culture of the intellectuals of his time. Paul was able to present the biblical message to Jewish and Greek intellectuals. A study of his methods and preaching may help biblical communicators to improve the methods to reach the intellectuals of our time.

\section{Paul: A Jew Born in Tarsus}

Paul was a member of an upper middle-class Jewish family of Tarsus, a city between the mountains and the sea, the capital of the Roman province of Cilicia.

Paul's family must have been a member of the upper middle class in Tarsus. . . . Jews enjoyed a favorable legal status during most times, and many took advantage of this and became citizens of their cities. The members of Paul's family were citizens of Tarsus (Acts 
21:39). More important, they were Roman citizens as well (Acts 16:37). This was an honor, which only official Rome could grant and which Paul's family had obtained before his birth (Acts 22:28). . . . The family's Roman citizenship reflects a high social position and, probably, was granted to it for having done some worthwhile service to the Empire. ${ }^{1}$

Tarsus was an active center of Hellenistic culture. It is possible that Paul received some kind of education in Tarsus before his family moved to Jerusalem. According to Act $22: 3$ and $26: 4$, Paul was educated as a scribe in the school of Rabbi Gamaliel.

Paul used the Greek language and culture in preaching the message, but he always remained faithful to the biblical truth. Paul says of himself in Phil 3:5: "Circumcised on the eighth day, of the people of Israel, of the tribe of Benjamin, a Hebrew of Hebrews; in regard to the law, a Pharisee."

Paul chose to become a Pharisee. About the Sadducees and the Essenes, the Pharisees represented a mediating position. They were apocalyptically oriented but not obsessed like the Essenes. They lived in society in the midst of all its trials and temptations, but they were not thirsty for worldly power like the sadducees. Unlike the Sadducees, who believed God left men alone to their own devices, and unlike the Essenes, who believed that the divine completely controls human history, the Pharisees believed that man's free will and God's providence operated side by side in some kind of undefinable tension. Therefore, though the affairs of the world are ultimately in God's hands, human

${ }^{1}$ Herold Weiss, Paul of Tarsus (Berrien Springs, MI: Andrews University Press, 1986), 4, 5. 
beings are responsible for their actions. ${ }^{1}$

Evidences of his Pharisaic training are recognizable in the typical rabbinic arguments and interpretations of Holy Scripture that we find in Paul's writings. In Gal 1:14 Paul relates that he "was advancing in Judaism beyond many Jews of his own age and extremely zealous for the traditions of my fathers."

Paul followed the biblical linear conception of time, which was the foundation of Jewish apocalyptic eschatology. He spoke in his epistles of two ages, the present age and the age to come: "Not only in the present age but also in the one to come" (Eph 1:21).

According to Paul, human beings are living in the present evil age. Satan, the god of this age, blinds the minds of unbelievers and hinders them from seeing "the light of the Gospel of the glory of Christ" (2 Cor 4:4). God, in Christ, has defeated the forces of impiety and soon will establish His kingdom, a new heaven and a new earth.

\section{Paul, the Apostle to Jews and Greeks}

Paul preached the gospel to Jews and Greeks. He himself declared:

To the Jews I became like a Jew, to win the Jews. To those under the law I became like one under the law

\footnotetext{
${ }^{1}$ Ibid. , 10.
} 
(though I myself am not under the law), so as to win those under the law. To those not having the law I became like one not having the law (though I am not free from God's law but am under Christ's law), so as to win those not having the law. (1 Cor 9:20, 21)

Paul presented the biblical message according to the kind of people who were receiving it. His preaching was different in the synagogue to the Jews from that outside to the heathen. The heathen, differently from Jews, needed to change all their old customs and worldviews.

In the synagogue, Paul first showed that God prepared the revelation of the Messiah through the history of Israel. The gospel was not a denial of old revelation, but a fulfilment. Afterward, he presented the facts of the incarnation, crucifixion, and resurrection of Christ, as foretold by the prophets and witnessed to by Christ's disciples. Finally, he proclaimed the message of pardon for all who received Christ, and a warning about the consequences of rejection of the message.

\section{Paul's Preaching to Intellectual People of His Time}

The book of Acts records several examples in which the Apostles presented the biblical message to the Gentiles, who naturally perceived the message according to their world view.

There are two examples of Paul's preaching to the 
heathen: the speeches at Lystra and Athens. Both were specifically adapted to the circumstances. In both episodes Paul received feedback that helped him to perceive in what ways his message was wrongly understood. He could thus improve the presentation of his message and help people to comprehend it better.

In the healing of a man "crippled in his feet" (Act 14: 8) at Lystra, Paul and Barnabas communicated the biblical message by both deed and word (Act 14:6-10). The crowd of Lystra interpreted the miracle performed by Paul in terms of the world view of their religion. They believed that only the gods could perform this miracle and assumed that "the gods have come down to us in human form!"(Act 14:11). They wanted to offer sacrifices to Paul and Barnabas. This circumstance certainly conditioned Paul's speech.

What is more interesting for the present study is Paul's speech at Athens, because it was addressed to a group of Greeks, among whom were Epicurean and Stoic philosophers, whose thought bears some similarities to that of secular people of our time.

In Athens, Paul, according his custom, preached in the Jewish synagogue to Jews and to "the Godfearing Greeks." He also preached in the marketplace to the people whom he found there. 
While Paul was waiting for them in Athens, he was greatly distressed to see that the city was full of idols. So he reasoned in the synagogue with the Jews and the Godfearing Greeks, as well as in the marketplace day by day with those who happened to be there. (Acts 17: 16, 17)

Preaching in the marketplace was not Paul's usual

method, but he adopted the custom used by the people who lived in Athens. Certain philosophers, hearing the preaching of Paul in the marketplace, noted the frequent occurrence of the terms "Jesus" and "resurrection." "Some

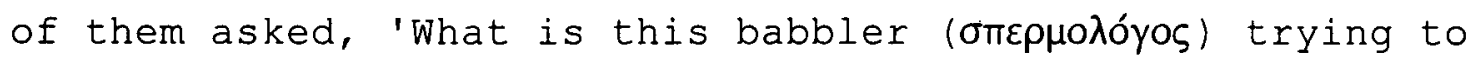
say?' Others remarked, 'He seems to be advocating foreign gods'"(Acts 17:18).

$\Sigma \pi \varepsilon \rho \mu$ oxóyos is not a very usual word. . . It is actually a term of abuse, whose approximate meaning is one who goes about the streets and markets picking up words of wisdom from great teachers, and then passes himself off as such an one. . . . The use of the plural form 'strange gods', $v$. 18, might indicate a misunderstanding on the part of the audience, causing them to take óvóotaoıs as a separate deity. ${ }^{1}$

Apparently some thought that Paul was proclaiming two new gods, namely "Jesus" and "resurrection." They arrived at this conclusion based on their religious background. Being intrigued to hear more, they brought him to the Areopagus and asked him to tell them more about these "strange" new ideas.

${ }^{1}$ Bertil Gartner, The Areopagus Speech and Natural
Revelation (Copenhagen: Almquist \& Wiksells, 1955), 48 . 
The Areopagus Speech

Athens was the intellectual and artistic capital of the world. It was a city known for its art, literature, science, and philosophy. Its streets and buildings were crowded with exquisite artistic works. In Athens, Socrates, Plato, and Aristotle had lived and taught. Their successors had elaborated different philosophical systems.

In the city of Pericles and Demosthenes, of Sophocles and Euripides, Paul, the Jew of Tarsus, preached the biblical message. Here people, representing two conflicting worldviews such as the Greek and the Hebrew, met together. Luke mentioned Epicureans and Stoics as listeners of Paul and not Academics and Peripatetics. The schools of the Epicureans and Stoics were those most influential at that time.

In what sense was their thought similar to that of secular people of our time? The Epicureans, as we have seen, ${ }^{1}$ accepted the atomism of Democritus--everything was composed of atoms. Even the gods were formed by thinner atoms. Their thought was a particular form of materialism combined with a form of "deism"/they admitted the existence of gods who did not worry about humans). A form of lifestyle that sought serenity by eliminating all kinds of

\footnotetext{
${ }^{1}$ See pp. 32, 33 above.
} 
fears. Humans ought to fear neither gods, nor destiny, nor death, which eliminates all problems. Prayers and sacrifices to, and worship of, gods were regarded as useless. Death was regarded as the end of both soul and body.

Stoics believed in a form of pantheistic materialism. Reality was formed by passive matter and an active principle, the Logos who was at the same time the WorldReason, the World-Law (lex naturalis), Providence and Fatum. Cosmic reason was not an autonomous, personal spirit, but the final reality, that was, an orderly arrangement of matter. God, Reason, Fate, and Nature were the same and only thing.

The difference between Epicureans and Stoics was that the latter accepted the idea of Providence, even if it was confused with nature.

In Athens, Paul presented the biblical message in a wonderful way. He was "greatly distressed to see that the city was full of idols." However, even if his heart hurt seeing so much idolatry, he gave his message in a positive form: "I see that in every way you are very religious" (Acts 17: 22). He had found an altar dedicated, to an Unknown God. He presented the God of the Bible as the Unknown God. By doing so he established some connection between his message 
and their beliefs. This Unknown God ("Aүvwotos @eós), he declared, created the world and everything in it and cannot be confined to temples built by humans.

The God who made the world and everything in it is the Lord of heaven and earth and does not live in temples built by hands. And he is not served by human hands, as if he needed anything, because he himself gives all men life and breath and everything else. (Acts 17:24, 25)

Paul did not directly attack the absurdity of paganism. Rather, he tried to help them reflect upon their beliefs and draw some rational conclusions. It is not God who needs men; it is human beings who need God. "God gives all men life and breath and everything they need" (Acts 17:25). God concerns Himself with humans and acts in human history.

From one man he made every nation of men that they should inhabit the whole earth; and he determined the times set for them and the exact places where they should live. God did this so that men would seek him and perhaps reach out for him and find him, though he is not far from each one of us. For in him we live and move and have our being. As some of your own poets have said, 'We are his offspring'. (Acts 17:26-28)

God "determined the times (kaıpoús, tempora, momenta)

set for them and the exact places (ópotroías, terminos), where they should Iive set for them," and "he has set a day when he will judge the world" (Acts 17:26). Paul introduced the linear-time concept of the Bible, which was contrary to the circular-time idea of the Greeks. ${ }^{54}$

${ }^{54}$ See pp. $212-214$ below. 
Men are sons of God, "offspring from God." Again, utilizing Greek poets, he established a connection between the beliefs of the Greeks and the biblical message. He drew a rational deduction: "Since we are God's offspring, we should not think that the divine being is like gold or silver or stone--an image made by man's design and skill" (Acts $17: 29$ ).

Afterward, he declared the willingness of God to forgive the past, but then warned about the danger of rejecting the message. "In the past God overlooked such ignorance, but now he commands all people everywhere to repent" (Acts 17:30).

Finally he presented the judgment and Christ: "For he has set a day when he will judge the world with justice by the man he has appointed. He has given proof of this to all men by raising him from the dead" (Acts 17:31).

It seems that when Paul spoke of the resurrection of the dead, the Greek hearers reacted negatively and interrupted him so that he had no opportunity to prove what he had affirmed.

The Stoics, even if they accepted the possibility of the survival of the rational part of the soul at death, considered the teaching of the resurrection of the entire human being to be absurd. 
The Epicureans believed that the body and the soul formed an indissoluble complex of atoms, which crumbled to nothing on dying. For them, any thought about the possibility of life after death was meaningless.

There were three distinct reactions to Paul's speech. Some "sneered." They wanted only to hear something new. Their hearts were not open to the influence of the Holy Spirit. Nevertheless, not all rejected the message of Paul. Some of them asked to hear him "again on this subject" (Acts 17:32). Certainly, the message had an impact on them, even if they were not humble to acknowledge and not yet ready to accept the true God in their lives.

Among those who listened to the words of Paul were some to whose minds the truths presented brought conviction, but they would not humble themselves to acknowledge God and to accept the plan of salvation. No eloquence of words, no force of argument, can convert the sinner. The power of God alone can apply the truth to the heart. He who persistently turns from this power cannot be reached. ${ }^{1}$

A few did accept the message presented by Paul. "A few men became followers of Paul and believed. Among them was Dionysius, a member of the Areopagus, also a woman named Damaris, and a number of others" (Acts 17:34). When the message is presented to skeptical intellectuals generally only a few accept it. However, later this little group

${ }^{1}$ Ellen G. White, The Acts of Apostles (Boise, ID: Pacific Press Publishing Association, 1989), 239, 240. 
helped others to believe.

\section{Other Characteristics of Paul's Message}

The characteristics of the message presented by the Apostle to the intellectuals of Athens have been examined above. Before closing this chapter, we consider some other characteristics of Paul's missionary methods.

The Apostle Paul used different methods of presenting the biblical message to different people. For example, in the speeches at Lystra and Athens he did not quote the old Testament because his hearers in those occasions were heathen (Acts $14: 8-18 ; 17: 16-34$ ). However, as we have seen, ${ }^{2}$ when he spoke to Jews he quoted the old Testament and referred to episodes of the history of the people of Israel (Acts 13: 14-43; 17:10-11).

Paul, aware of the difficulties, sufferings, and oppressions of the people of his time, helped them to find a solution to their problems. (For example, healing people: Acts $13: 8,9 ; 28: 8-10)$.

The message of the Apostle was not superficial. There are so many deep thoughts in his epistles that even today scholars continue studying them, finding in them new inspiration.

${ }^{2}$ See p. 139 above. 
Paul preached the gospel with much suffering. He was persecuted, lashed, and imprisoned. His sufferings were a clear proof of his sincerity and honesty (2 Cor 11:21-28).

The message of Paul was inspired by the Holy Spirit. It was of a wisdom which was not of this age, nor that of the rulers of this age (secular wisdom), but of God (1 Cor 2:6).

\section{Some Einal Considerations}

In his message Paul always tried to say something about a common belief that created sympathy and a bond of union. He preached the new truth in a way that showed it was in harmony with something the hearers already knew and believed.

He presented his message to Jews based on the Holy Scriptures. In this case his textbook was the old Testament. "As his custom was, Paul went into the synagogue, and on three Sabbath days he reasoned with them from the Scriptures" (Acts 17:2).

When Paul presented the message to the Gentiles, he adapted it to their background. He became like "one not having the law to those not having the law. . so as to win those not having the law" (1 Cor 9:21).

Finally, he generally presented some warnings about the terrible consequences of an eventual rejection of God's message. 


\section{9}

Many of the methods of the Apostle Paul are valid today and can be applied in the presentation of the biblical message to secular people of our time. 
CHAPTER VIII

\section{THE PROCESS OF COMMUNICATION: LANGUAGES, CULTURE, AND THE BIBLICAL MESSAGE}

\section{Introduction}

The purpose of this dissertation is to explore the possibility of an intellectual approach to communicate the biblical message to secular people. How is it possible to communicate the message in an effective way? Generally, people do not pay attention to the process of communication and often communicate wrongly. It can happen that the message transmitted is received differently by the receptor.

It is important to consider how to communicate with secular people in a way that they can understand the message. For example, the language is the means through which people express their thoughts and feelings. It is necessary to examine the type of language that communicators must use with secular people.

Central to culture is language. The language of a people provides that means by which they express their way of perceiving things and of coping with them. Around that center one would have to group their. . . arts, their technologies, their law. . . . Religion-including the Christian religion--is thus part of 
culture. ${ }^{1}$

Culture organizes and guides the thinking, feelings, and actions of human beings by rules and patterns, which many times remain largely unconscious. Humans are not as free as they imagine themselves to be. Their mental behavior is influenced by culture.

Secular people have their particular culture ("the modern Western"). ${ }^{2}$ The Bible has been transmitted through a specific culture (the Hebrew culture). ${ }^{3}$ The biblical communicator has his/her culture (a culture transformed by the relationship with God).4 The presentation of the biblical message to secular people entails the encounter between different cultures.

But what is culture and how is possible to reach this encounter? It is convenient to define culture and to examine in what way the three cultures encounter each other.

The weakness, however, of this whole mass of missiological writing is that while it has sought to explore the problems of contextualization in all the cultures of humankind from China to Peru, it has largely ignored the culture that is the most widespread, powerful, and persuasive among all contemporary cultures--namely, what I have called

${ }^{1}$ Newbigin, Foolishness to the Greeks, 3 .

${ }^{2}$ Ibid.

${ }^{3}$ See pp. 170, 172 below.

${ }^{4}$ See pp. 171, 172 below. 
modern Western culture. Moreover, this neglect is even more serious because it is this culture that, more than almost any other, is proving resistant to the gospel.1

In this chapter, first, the process of communication is examined; second, after a brief definition of the word culture, the "encounter between the gospel and the culture that is shared by the peoples of Europe and North America" 2 is considered.

Particularly, the process through which the biblical message must be transmitted to secular people and the relationship between western culture and the biblical message is examined.

\section{The Process of Communication}

Communication is a process by which one transmits a message to an audience by means of signals. The hearers in turn receive, decode, understand or misunderstand, and react to it.

The transmission of the message is only one side of communication. Communication depends not only on what is transmitted but also on what is received. Effective communication requires two-way involvement. Communication and involvement are inseparable.

${ }^{1}$ Newbigin, Eoolishness to the Greeks, $2,3$.

${ }^{2}$ Ibid., 1 . 
It is important to control not only what biblical communicators send, but also exactly what secular people understand of the message sent to them.

Factors such as language, beliefs, values, worldview, and emotions are all filters that influence the receivers and can hinder or facilitate the reception of the message. Often with the main message there may be many other unconscious secondary messages. These paramessages can distort the intended meaning of communication. For the receptor they may become more important than the main message. The attitudes manifested by the communicator toward receptors can impress them more than the same message. For example, biblical communicators must take care of the manner in which they prepare and deliver their lectures. Often they strongly attack the mentality of secular people and harshly criticize the results of science and technology. Their real or supposed mistakes may be presented in an ironic way. This is not the right way to communicate with secular people.

God asks us to present the truths of the Bible, not the mistakes of others. The biblical message must be presented in a positive way. It is important to appreciate the positive results of science and technology and not only to show the problems caused by them. 
It is not possible to deny that the positive results obtained in medicine and surgery have prolonged the lives of many. Certainly communicators, or some members of their family, have benefitted from these results.

They must also recognize that the results obtained by science and technology in telecommunications will help them to present the biblical message more rapidly to all nations. Why, then, present science and technology only negatively?

The manner in which receptors understand the message depends not only upon how communicators send but on how the receivers perceive it. If communicators want a substantial correspondence between what they communicate and what their hearers really understand, they must be receptor-oriented. Hiebert wrote:

How do we measure successful communication? Ordinarily we think we have communicated when we send a message. For example, as missionaries we measure our communication by the number of sermons we preach, classes we teach, or time we witness. And when the people misunderstand us, we say, "But I said. . . or "You weren't listening." In all these cases we are assuming that communication implies only the sending of messages. . . As Charles Kraft (1979) points out, communication must be measured not by the messages we send but the messages the people receive. In other words, our communication must be receptor-oriented. It must be understood by the people and meet their needs.

People can understand new information only in relation

${ }^{1}$ Hiebert, Anthropological Insights for Missionaries, 
to existing beliefs and values. Generally a deep clash with old beliefs or values may result in rejection of the biblical message. As we have seen, the Apostle Paul presented the message to people in a way that was in harmony with something that the hearers already knew and believed. He presented the message using the language and cultural forms of the people who heard them.

Feedback completes the circle of communication. It gives to communicators the assurance that their communication has been a dialogue and that the receiver has understood the message. The response is usually prompt and immediate in the small group. We have seen how paul could improve the presentation of his message when he perceived that his hearers had misunderstood his message. ${ }^{2}$

How do we know when our messages are misunderstood? The answer, in part, is feedback--Iistening to those receiving the message. . . Feedback should modify our communication, immediately and continually. . . . If they are hostile, dubious, or rejecting, we must stop to build trust and examine our own paramessages for possible sources of misunderstandings on the affective level. ${ }^{3}$

The larger the audience the greater the diversity of its culture. This makes effective communication more

${ }^{1}$ See pp. 139 above.

${ }^{2}$ See p. 140 above.

${ }^{3} \mathrm{Hiebert,}$ Anthropological Insights for Missionaries, $164,165$. 
difficult. That is why the communicator must determine the best size of the audience. There are various types of audiences: an intimate audience of one or two persons, a small group of twelve to twenty-five, and a large group of twenty-five to seventy-five or more.

Initially secular people prefer a large audience so that they can keep their anonymity. Little by little it is possible to establish bonds of friendship with them. At that time, the best size of the audience is from two to twelve, because small meetings facilitate discussion and decisions. A person-to-person encounter, or at least a small group, gives secular people the opportunity to present their reactions and allow the communicator to observe the feedback, because it is possible to listen to those who are receiving the message.

The communication is more effective if the communicator and the receptor share the same cultural frames of reference. If receptors classify the communicator with stereotypes as unintelligent, incoherent, a fool, an uncultivated person, communication will have a low impact.

It is necessary that the communicator earns high credibility in order to have high-impacting communication. The biblical message must first produce a high impact in the life of the communicator if one wants a strong impact on the 
receptor.

There are at least two dimensions in the common process of communication: the rational and the emotional. The rational is a conscious act, whereas the emotional generally is involuntary. When people communicate the biblical message, it is necessary to consider all three dimensions of human being: the rational, the emotional, and the spiritual. Not only must the minds of secular people be impressed by the rationality of the biblical message, the hearts by the emotional aspect of it, but also their spirits by the Holy Spirit.

The purpose of the communication of the biblical message is to help secular people establish an effective relationship with God. It is wonderful that God is available to reveal Himself to human beings and to establish a relationship with them. Communication of the biblical message is complete only when the hearer receives a clear invitation to establish an effective relationship with God and convert to Him.

Only with the help of God is it possible to have an effective communication of the biblical message, because God can speak to the conscience of receivers.

However, if it is truly the communication of the gospel, it will call radically into question that way of understanding embodied in the language it uses. If it is truly revelation, it will involve. . a radical 
metanoia. . . This radical conversion can never be the achievements of any human persuasion, however eloquent. It can only be the work of God.'

Biblical communication to secular people must always be accompanied by prayer and the guidance of the Holy spirit. The Holy Spirit, working in human hearts, helps biblical communicators in the presentation of the message to secular people.

\section{Languages and the Biblical Message}

God meets human beings. Obviously, in His encounter with humans, God must use their language and culture in order to communicate an understandable message.

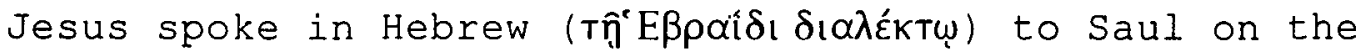
road to Damascus (Acts 26:14).

Language is a dynamic living thing, which changes through time and sometimes even dies. Many Christians are attached to antiquated forms of preaching, worshiping, and theologizing.

Many words that we find in the Bible today have a meaning different from what they had at the time of biblical writers. If biblical communicators want to be understood by secular people and avoid misunderstandings, they must use modern words that express the same meaning which biblical

${ }^{1}$ Newbigin, Foolishness to the Greeks, 6 . 
words had at the time when they were used. Words like flesh, soul, breath, spirit, world, sin, grace, justice, faith, holiness, kingdom, and regeneration have a particular meaning in the Bible, but not the same meaning for the people of today.

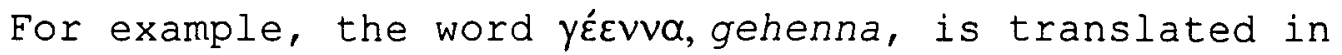
the King James Version and in the New International Version with the word hell. According to the dictionary, hell is "the abode of condemned souls and devils. . . the place of eternal punishment for wicked after death, presided over by Satan. The abode of the dead, identified with the Hebrew Sheol and the Greek Hades, the underworld." 1 This is the meaning that individuals who began to read the Bible gave to this word. But gehenna, yérvva, does not mean "the abode of

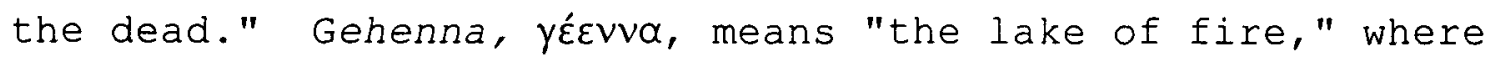
all people will be thrown whose names are not found written in the book of life after the second resurrection (Rev $20: 11-15)$

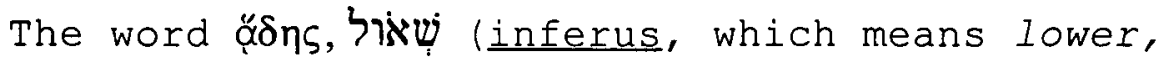
underground), indicates the state, the condition of absolute unconsciousness, in which the dead--good and evil--are found from the moment of their death until the moment of the first

\footnotetext{
${ }^{1}$ The American Heritage College Dictionary (Boston: Houghton Mifflin Company, 1993), s.v. "hell."
} 
or the second resurrection (Rev 20:4-5).

It is necessary to clarify the meaning in which the words are used in the Bible in such a way as to avoid any possible misunderstanding.

Christians claim to offer people the living word of God, but many sermons, speeches, and lectures are really dead things, because they are expressed in an old, formal abstract language completely separated from current life.

For those of us who live or have lived in the special enclosure called 'church' the words are almost too familiar. We know them as a smooth and worn conventional medium, part of the accepted furniture of the sacred. They define the religious manner and we use a special tone when we speak them. . . The man outside the sacred enclosure dismisses the inside lingo as nonsense. The Christian argot does not seem to refer to anything and does not belong to the world of turnips and carburetors. . . . That Christian language is a pious mannerism, a set of professional counters, signifying nothing, embodying nothing. It afflicts all our religious language; including that which masquerades in the guise of modernity. The second danger is sleepiness. ${ }^{1}$

The Bible is the living Word of God, God's revelation to humanity. God wants us to make his revelation available to everyone. Every person must be able to understand the biblical message.

The biblical truths are neither ancient nor contemporary. They are timeless and therefore always

${ }^{1}$ David Martin, The Breaking of the Image (New York: St. Martin's Press, 1980), 123, 124. 
relevant. It is necessary that communicators express them in a language accessible to the minds of people who are hearing them.

Not only the old language but also the abstract terminology of speculative thought must be avoided. The message ought to be presented in concrete terms of ordinary human experience. The Bible must be presented in a concrete way, in terms that the ordinary man can understand.

The main function of language is communication, but every human language is something more than a vehicle through which human beings exchange ideas and information and more than a tool through which they express their emotions and desires. Every language is also a special way of looking at reality and interpreting it.

A whole set of assumptions about physical nature and human life is hidden in the structure of each different language. The human mind uses language as a means of categorizing the events of nature. It never reports objective experience without variation, but always operates selectively as an interpretation of reality, according to the worldview of a particular culture and the experience of the observer. Some features of the external world are highlighted and others are ignored.

Secular people have their own worldview. Their 
language expresses their way of perceiving reality.

Biblical communicators must use the language that secular people can understand, but everytime there is a misunderstanding, it is necessary to clarify the meaning of the words and expressions used.

\section{Defining Culture}

A. Kroeber and C. Kluckhohn, in Culture: A Critical Review of Concepts and Definitions, list 164 definitions of culture. In the last part of their book they present the central idea expressed by anthropologists in their definitions:

Culture consists of patterns, explicit and implicit, of and for behavior acquired and transmitted by symbols, constituting the distinctive achievement of human groups, including their embodiments in artifacts; the essential core of culture consists of traditional (i.e., historically derived and selected) ideas and especially their attached values; culture systems may, on the one hand, be considered as products of action, on the other as conditioning elements of further action. ${ }^{1}$

Newbigin defines culture:

Let us begin with some preliminary definitions. By the word culture we have to understand the sum total of ways of living developed by a group of human beings and handed on from generation to generation. Central to culture is language. . . Around that center one would have to group their visual and musical arts, their technologies, their law, and their social and political

${ }^{1}$ A.L. Kroeber and Clyde Kluckhohn, Culture: A Critical Review of Concepts and Definitions (New York: Vintage Books, 1963), 357 . 
organization. And one must include in culture, and as fundamental to any culture, a set of beliefs, experiences, and practices that seek to grasp and express the ultimate nature of things, that which gives shape and meaning to life. ${ }^{1}$

In this dissertation culture is defined as a transmitted pattern of meanings embodied in symbols, and an integrated system of ideas, feelings, and values, which a group of people has built up and transmitted from one generation to another.

Human beings interact with one another according to their preconceived mental patterns, their culture, and their perceptions of the world. This perception depends on their assumptions of reality.

\section{Enculturation and Acculturation}

Our world is a global community in which people of different cultures are living together, sharing the same natural and human resources.

According to Durkheim's classic definition, social facts have three basic characteristics. They are:

(a) general: that is to say, they are common to many individuals;

(b) transmissible: that is to say, they can be transmitted vertically from generation to generation and horizontally from one contemporary human group to another;

(c) compulsory: that is to say, human beings have to take account of them, whether they like them or not--

${ }^{1}$ Newbigin, Eoolishness to the Greeks, 3 . 
they cannot be ignored. ${ }^{1}$

Human infants are born into a preexisting culture; they do not inherit it. They must learn the language and acquire the culture within their own context and are shaped by it. Parents teach culture to their children. Anthropologists call this process enculturation.

Culture can be transmitted not only vertically, but also horizontally; every group of people can transmit culture to the members of another contemporary group. Human beings have the possibility of modifying their cultural traditions through contact with people of other cultures. Acculturation is "the process of interaction between two societies in which the culture of the society in the subordinate position is drastically modified to conform to the culture of the dominant society."2

Clearly in the presentation of the biblical message it is necessary to avoid any form of psychological, political, or economical impositions. The message must be freely accepted without any kind of coercion.

\section{Contextualization}

Often communicators are so dominated by their own

${ }^{1}$ Shorter, Toward a Theology of Inculturation, 32 .

${ }^{2} E$. Adamson Hoebel, Anthropology: The Study of Man (New York: McGraw-Hill Book Company, 1966), 559. 
Western culture that they make no distinction between Christianity and it. They perceive the message as part of the Western cultural package and consequently they find many problems in presenting the biblical message to people of a different culture.

\section{Biblical communicators must make a clear distinction}

between Western culture and the biblical message. Often secular people resist the gospel because it is presented in the old Western traditional cultural forms, which they cannot understand.

In the last couple of decades there has been a spate of missionary writings on the problem of contextualization. . . . The weakness of the former was that it tended to relate the Christian message to the traditional cultural forms--forms that belonged to the past and from which young people were turning away under the pervasive influence of "modernization.". . . The value of the word contextualization is that it suggests the placing of the gospel in the total context of a culture at a particular moment. ${ }^{1}$

It is necessary to communicate with secular people by using the language and culture they understand. Biblical communicators ought to become familiar with the secular mind and present the message in an understandable way.

Communicators have learned the Bible "packaged" in old cultural forms and many times presume that these are the best. Frequently they manifest a condemnatory attitude

\footnotetext{
${ }^{1}$ Newbigin, Foolishness to the Greeks, $2,3$.
} 
toward all contemporary cultural forms. They must present the biblical message, God's plan of redemption, in a form that secular people can understand and appreciate. They ought to help every individual to enter into a relationship with God.

Secular people perceive reality filtered through their cultural glasses. It is necessary to "translate" the biblical message in terms they can understand if communicators want to present it in a relevant and understandable way. Thus, secular people can be pushed to compare the biblical message with their secular worldview. Human beings do not interact blindly. They reflect mentally about their interactions.

The process through which the biblical message can be transmitted without misunderstandings is, according to anthropologists, called contextualization.

The process of contextualization is very different from those of enculturation and acculturation. Through the latter it is possible to teach and learn a particular culture: the culture of our own group or that of one's host group. Through the process of contextualization people do not teach any culture, but use the receptor's language and culture as the means to communicate the biblical message. The purpose of true contextualization is not the 
transmission of a culture, but to help people meet God and establish a deep relationship with Him. Obviously, the contact they establish with God necessarily produces changes in their ways of thinking, feeling, and living, and consequently in their worldview.

Any effective communication of the biblical message produces changes in the fundamental worldviews of the people who receive the message. If this does not happen, the communication has been superficial.

\section{Critical Contextualization: An Approach Suggested by the Anthropologist Hiebert}

Anthropologists distinguish between practical and symbolical aspects of culture. Beneath the phenomenological level of culture lies the level of meanings and values.

Scholars think that in each culture there is a series of four levels, which differ in importance and resistance. As one descends from the external to the most intimate level of human personality, ${ }^{1}$ more and more one finds resistance to change.

The first, industrial technology (communication, travel, sport, fashion), does not deeply affect human beings. Changing it is easy. The second, family

${ }^{1}$ Personality is the sum total of behavioral, temperamental, emotional, and mental traits, overt or covert, characteristic of a person. 
conventions and etiquette, affects the individual more deeply and therefore is more difficult to change. Values form the third level. Every culture has its own characteristic values. They are instilled in the members of a society through enculturation. The fourth level is that of worldview. Every culture has its particular way of understanding the world. Obviously, as one approaches the inner level, the change becomes more difficult.

There are levels of culture and there is a hierarchy of importance among the levels. . . As one descends more deeply to the innermost levels of the cultural personality, one encounters more resistance to change. While the outer, practical levels are susceptible of change, it is much harder to change people's values, harder still to change their world view. It now becomes clear why evangelization is a fundamental challenge to culture. This challenge is, perhaps, greater when it is more subtle, when it is not part of a process of cultural domination or alienation. ${ }^{1}$

The encounter with God transcends the level of sensible experience of human beings. God acts at the most inner level of human personality, at the same roots of human culture, and gives to human experience a new dimension. According to Nicholls, there are two different levels of contextualization: one cultural, the other theological.

We may speak of two levels of contextualization-cultural and theological. The former relates primarily to the two surface levels or segments of culture... . namely, the institutions of family, law, education and the observable level of cultural behavior and the use

${ }^{1}$ Shorter, Toward a Theology of Inculturation, 36, 37 . 
of artifacts. These tend to be the preoccupation of the anthropologist and sociologist whose approach is more phenomenological. . . On the other hand, the deeper levels of culture, namely, the world view and cosmology and the moral and ethical values . . are the primary concern of the theologian.

Cultural contextualization concerns change at only the first two levels of culture, while theological contextualization concerns the level of the worldview and values.

When the Bible really enters into the life of a person, an encounter with God will be produced. Then the Bible will judge and change the way of thinking, feeling, and living of the people who receive it and will transform their lives.

The supracultural, absolute, and infinite God bridges the gap that exists between Him, who is totally free from human culture, and human beings, who are totally immersed in culture, communicates with them, and transforms their worldviews and values.

However, when communicators try to present the biblical message to people of a different culture, Newbigin points out that there are two major dangers: syncretism and irrelevance. He suggests that gospel workers seek a path between these two dangers.

${ }^{1}$ Bruce J. Nicholls, Contextualization: A Theology of Gospel and Culture (Downers Grove, IL: Intervarsity Press, 1979), 24 . 
Clearly, he has to find the path between two dangers. On the one hand, he may simply fail to communicate: he uses the words of the language, but in such a way that he sounds like a foreigner; his message is heard as the babblings of a man who really has nothing to say. Or, on the other hand, he may so far succeed in talking the language of his hearers that he is accepted all too easily as a familiar character. . . . In the attempt to be "relevant" one may fall into syncretism and in the effort to avoid syncretism one may become irrelevant. ${ }^{1}$

On the one hand, there is a danger of adapting the

biblical message to the Western culture. On the other hand, there is the danger of presenting the biblical message using old and/or abstract language and a consequent irrelevance.

The Apostle Paul affirmed that the revelation of God is for Jews and Gentiles. We have seen, that Paul used different methods when he presented the biblical message to Jews or to heathens. With Jews he used verses of the old Testament and referred to episodes of their history; with Gentiles he presented the biblical message using their language and cultural forms. In every instance, the message was presented without any alteration. The same methods must be applied in the case of secular people.

Secular people have their own particular culture, which is the result of the process of secularization. If communicators want the biblical message to be understood and relevant to the secular mind, they need to translate it in a

\footnotetext{
${ }^{1}$ Newbigin, Eoolishness to the Greeks, 7.
} 
171

language and culture that they can understand.

The biblical message must remain constant, while the presentation must be expressed in a way that secular people can understand.

The biblical message is eternal because it comes from God; the language and historical-cultural forms, in which it is communicated to human beings, are temporary because they come from humans.

Marvin Mayers, in suggests integrating cultural relativism with biblical absolutism. He observes:

The approach of biblical absolutism and cultural relativism affirms that there is a supernatural intrusion. Truth is from God. Truth does not change. ${ }^{1}$

Biblical communicators must combine cultural relativism with biblical absolutism. There is real contextualization only when the biblical message leads individuals to conversion to the true God.

The Bible also presents God's message in a person who is part of a particular culture. Biblical communicators have the problem of needing to understand and identify at least three cultures: that of the Bible writers, that of the secular people to whom they want to communicate the biblical message, and their own.

${ }^{1}$ Marvin K. Mayers, Christianity Confronts Culture (Grand Rapids, MI: Academic Books, Zondervan, 1987), 249. 
The culture through which the biblical message was transmitted was the Semitic culture of Hebrew people.

The culture of secular people, as we have seen in the first part, is the modern Western culture, which is shaped, as correctly observed by Newbigin, as "the philosophy of the Greco-Roman world."1

The culture of biblical communicators is (or should be) a culture transformed by the biblical message, which has changed radically their religious, philosophical, ethical, and political thought.

Obviously, it is necessary to avoid any adulteration of the biblical thought with concepts foreign to the Bible. Hiebert suggests following the approach that he calls critical contextualization.

If both the uncritical rejection of old ways and their uncritical acceptance undermine the mission task, what should we and the christian converts do about their cultural heritage? A third approach may be called critical contextualization, whereby old beliefs and customs are neither rejected nor accepted without examination. They are first studied with regard to the meanings and places they have within their cultural setting and then evaluated in the light of biblical norms. ${ }^{2}$

According to Hiebert, it is also necessary to avoid any

${ }^{1}$ Leslie Newbigin, The Open Secret (Grand Rapids, MI: William B. Eerdmans, 1995), 82.

${ }^{2}$ Hiebert, Anthropological Insights for Missionaries, 186. 
form of compromise between Christianity and Western culture.

We are often aware of the need for evaluating the practices of other cultures when the gospel is first introduced into them, but we too easily take it for granted that our own culture, with its long history of Christianity, has already been molded by biblical values. The result, too often, is comfortable accommodation between Christianity and Western culture, including an uncritical acceptance of western cultural ways. This is true of many areas of life. ${ }^{1}$

On the other hand, many think that biblical orthodoxy

is possible only when biblical communicators use old

cultural forms. But this attachment to old forms prevents

secular people from accepting the message. Often Christian

people are "culturally alien and bizarre" to secular people.

But Kenneth Chafin was suggesting, a quarter century ago, that unchurched seekers experience our buildings, liturgies, stained-glass windows, organ music, ushers, offering plates, and "our people with their sunday faces on" as culturally alien, bizarre, and even intimidating." My own interviews with secular seekers who visited a church, but didn't join or return, have surfaced a widespread fear that the church wants to make them like "church people.". . . Typically, when secular people experience "church" as culturally alien to them, they assume that the Christian God is not for people like them; they believe they have to learn to dress, talk, tote Bibles, and genuflect like the Christians do, before God will accept them. ${ }^{2}$

Communicators encounter many problems when they try to communicate with secular people, if they present the message in very old and abstract cultural forms. These old cultural

${ }^{1}$ Ibid., 190.

${ }^{2}$ Hunter, How to Reach Secular People, $66,67$. 
and theological forms are so different from the ways of thinking, feeling, and living of secular people that they obviously do not understand the biblical message or consider it irrelevant.

Secular people. . . are reached more effectively through the people, language, liturgy, music, architecture, needs, struggles, issues, leaders, and style that are indigenous to their culture. We know that this cardinal principle of Christian mission applies to other mission fields, of course, but have not yet discovered its necessary application to our Western fields, because we haven't thought of what we do as "foreign" to unchurched people in the West. ${ }^{1}$

If communicators want the biblical message to be received by secular people, they must take the risk of expressing the biblical message in the language and thought forms of contemporary culture.

Biblical communicators must also express the biblical message in theological forms understandable to secular people, even if that approach can produce the fall of some traditional and conservative theological concepts.

\section{Contextualized Theology}

Some Christians think that it is necessary to retain the old traditional cultural forms in which they have received the biblical message, without any further change, because they fear that with the fall of the old cultural

\footnotetext{
${ }^{1}$ Ibid. , 66
} 
forms the biblical message could also fall.

However, this trend tends to build high and solid walls that hinder secular people from understanding and accepting the biblical message. However, it is important to take care that this process of "translation" does not alter the biblical content of the message, which must ever remain unchanged.

Often the theology taught in the seminaries cannot be used, because it is expressed in a conservative, abstract form that ordinary people cannot understand.

Many people have come to consider irrelevant the biblical message, because Christians have refused to take the risk of "translating" biblical thought into mental categories of the contemporary culture. Some of the thinkers who have fought against religion have been educated in seminaries.

On the other hand, some theologians assume that since all context is culturally conditioned and all knowledge is subjective there is not a single biblical theology, but several biblical theologies conditioned by the biblical writers' communities.

As we have seen, ${ }^{1}$ the minds of secular people are accustomed to logical and rational reasoning. That is why

${ }^{1}$ See p. 125 above. 
it is necessary to take extreme care to present no absurdity. How can a God who is eternal die? The "death of God theology" does not help to reach secular people; on the contrary, it makes the presentation of the biblical message very difficult.

Another example, made by Pannenberg, of an excessive assimilation of Christian theology to the spirit of secular culture is the theology of demythologizing. ${ }^{1}$

For Bultmann, "faith has nothing to do with a worldview, but only with existential human self-understanding."2 This means that any conception of a creation of the world and of eschatology must be abandoned. How is it possible that human beings renounce the hope of resurrection? The elimination of the worldview from religious faith limits religion to human temporary existence and religion becomes abstract and irrelevant.

If God could not truly be understood as the creator of this world, then the truth of belief in the one God would be threatened. But if God is the creator of the world, then we may expect that no phenomenon of the finite reality of this world, including human beings, is appropriately understood so long as it is seen apart from its relationship to God. . . The secular investigation of the reality of the world and human nature apart from God can be seen only as an approximation to the true reality of nature and humankind, and cannot be regarded as adequate knowledge

${ }^{1}$ See pp. 74-76 above.

${ }^{2}$ Pannenberg, Christianity in a Secularized World, 51. 
of this reality, if the biblical idea of God is to be maintained. ${ }^{1}$

As we have seen, ${ }^{2}$ secular people reject abstract

theologies separated from reality. Thus a theology that does not admit a possible "dialogue with the sciences" 3 is hardly acceptable to secular people.

Another incorrect form of presenting the biblical message to secular people is theological syncretism.

Theological syncretism destroys the authority of the Bible. Scripture no longer has a normative value and theology becomes undefined. It is necessary to avoid any form of theological syncretism to help secular people to harmonize their worldview with the biblical message and not, to the contrary, to harmonize the biblical message with the worldview of secular people.

\section{Summary}

In this chapter we have seen that communication of the biblical message to secular people is possible only if it is "translated" in their language and culture.

Every human culture is imperfect and needs to be improved. God, when He enters in the life of human beings,

${ }^{1}$ Ibid., 52 .

${ }^{2}$ See pp. 123, 124 above.

${ }^{3}$ Newbigin, Foolishness to the Greeks, 73. 
transforms not only their way of thinking, feeling, and living, but also their worldview.

The processes of communication and contextualization have been considered and, in particular, we have seen the difference between contextualization and critical

contextualization. We have also seen the dangers that must be avoided when communicators present the biblical message to secular people.

With this chapter we have ended the consideration of the means through which the message must be transmitted; in chapter 9, 10, and 11 the content of the biblical message is examined. 
CHAPTER IX

\author{
THE BIBLICAL MESSAGE: HOW TO PRESENT \\ GOD TO SECULAR PEOPLE
}

\title{
Introduction
}

The purpose of this dissertation is to investigate the most efficient and effective intellectual approach to the communication of the biblical message to secular people. Nevertheless, some practical aspects are considered in chapter 11 where the doctrine of the church as the people of God is presented.

In general secular people feel indifferent to organized religion. They are oriented toward this present life rather than to the hereafter. However, they too experience complexities and problems in life and can easily come to appreciate a supportive community that helps them cope with their difficulties. A sympathetic church community can fulfil this role and help to create an attitude of willingness to at least listen to the message of the Gospel. Later the community of faith can provide the support that encourages the secular friends on the road of spiritual 
growth. This is why some practical approaches related to the church and its various ministries are presented in this study

To present the biblical message to secular people is not easy. There are problems to resolve and dangers to avoid. The biblical message has been transmitted in the Hebrew culture. The first problem is to separate the biblical message from the Hebrew culture. It is also necessary to keep the biblical message separated from Western culture, without blending one with the other. This is perhaps the most difficult problem.

Finally, it is important to transmit it to secular people in the form of their culture without adulterating it. There is the danger of producing changes in order to adapt it to their mentality. Contextualization does not mean syncretism. The biblical message must be reformulated in the language of the receiver without adulteration.

Furthermore, the message ought to be presented not in a superficial, abstract, or dogmatic way but in a clear, relevant, concrete, and comprehensible one. It ought not to be separated from the reality that humans are living daily.

In this dissertation, obviously it is impossible to consider the entire biblical message. Only its essential parts will be dealt with. 
The communicator will follow the same criteria used in presenting the other parts of the message.

\section{Religion: An Encounter with God}

As we have seen, ${ }^{1}$ secular people reject religion but not necessarily God. It is very important to clarify to them the true biblical concept of religion.

The etymology of the word religion is uncertain. Some people think that the word religion (Latin religio) derives from the Latin verb religare (to unite, tie, join). In this case religion would be the bond that joins human beings with God.

Other scholars think that the word religion derives from the Latin verb relegere (to read again, review, reexamine). On this view, religion would mean to pay diligent attention to those things related to God.

Many definitions have been proposed for the religious phenomenon, but until now none of them has prevailed. It is difficult to find a clear concept of religion in archaic and Greek-Roman civilizations.

It is important to remember that no primitive language, no superior archaic civilization, not even the Greek or the Roman, closer to us, know a term that corresponds to this concept that historically has been defined in particular time and place. (One will observe that the term "religion" derives directly from the Latin

${ }^{1}$ See pp. 122 above. 
religio. . . But the Latin term did not have the modern meaning of religion. . . . . ${ }^{1}$

However, there is something that distinguishes religious phenomena from other phenomena? In the introduction of the Trattato di Storia delle Religioni, Mircea Eliade observes that a true definition of the word religion must consider the unique and irreducible quid that religion contains: its sacred character.

For Durkheim, at the heart of every religion stands the sacred. Religion rests on the simple fact that men from time immemorial and in all societies have given certain objects, people and ideas an inviolable status. . . Yet Durkheim did not see the sacred as an isolated concept. . . . The sacred is to be understood, and only has meaning, by reason of its opposite, the profane.

The dichotomy sacred-profane that western culture has

inherited from platonic dualism is one of many other

dichotomies on which sociological definitions of religion are based.

Many sociological definitions of religion operate with a basic dichotomy such as profane/sacred (Durkheim), natural/ supernatural (Parsons), nomos/cosmos (Berger), and empirical/super-empirical (Robertson). . . . The common thread through most of them is that religion is primarily about something beyond the normal, the everyday, the perceptible; and that somehow this radically other fundamentally conditions human

\footnotetext{
${ }^{1}$ Henri-Charles Puech, Historia de las Religiones (Mexico, DF: Siglo Veintuno Editores, 1970), 1:34, 35 (translation mine).

${ }^{2}$ W. S. F. Pickering, Durkheim's Sociology of Religion (London: Routledge \& Kegan Paul, 1984), 115, 117, 119.
} 
existence. ${ }^{1}$

However, all these dichotomies of Western culture are not found in the Bible.

According to Rudolf otto, the sacred, or the holy, is "the mysterium tremendum et fascinosum." ${ }^{2}$ According to

Edward Sapir, men are capable of proceeding toward ultimacy and entering into a relationship with an ultimate ground of existence and value. The holiness of persons and things does not depend on the intrinsic nature of persons or things, but on their relationship with God.

The renowned contemporary theologian, Paul Tillich, has emphasized the centrality of the encounter with ultimacy in the religious experience. . . . In religion . . we do not simply come into contact with things. We do not simply meet "objects of a cognitive approach but elements of an encounter, namely the encounter with the holy. . . . As a Christian theologian, Tillich sees the holy involving a person-to-person relationship to God. ${ }^{3}$

On the one hand, in the Bible we cannot find a word that means religion. Some translate the Greek terms

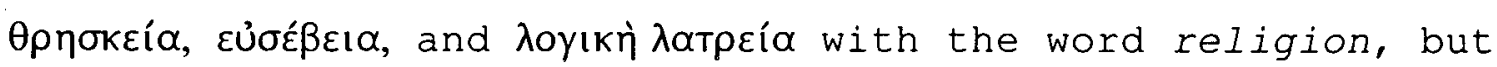
these terms really mean worship, piety, devotional observances.

${ }^{1}$ Peter Beyer, Religion and Globalization (London: Sage Publications, 1994), 5 .

${ }^{2}$ Thomas F. O'Dea and Janet O'Dea Aviad, The Sociology of Religion (Englewood Cliffs, NJ: Prentice-Hall, 1983), 23. ${ }^{3}$ Ibid., 29, 30 . 
The Lutheran theologian quenstedt quotes as synonyms of

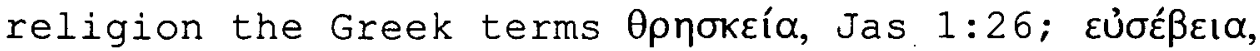

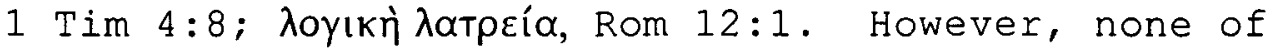
these terms is really a synonym of religion, even if each one of them indicates or points to a particular aspect of it. ${ }^{1}$

According to sociologists, it is very difficult to find a satisfactory definition of religion that embraces the various kinds of so-called religion because of the important differences of function among the various systems known.

In this dissertation, religion is regarded as the way of belief and life based on a person's relation to God. The Bible underlines the importance of the encounter and relationship with God. Every human being must convert to God. Barnabas and Paul invited the crowd of Lystra to convert to the living God ('̇mı

We are bringing you good news, telling you to turn to the living God (દ́mı vivum), who made heaven and earth and sea and everything in them. (Acts 14:15)

According to the Bible, holiness is an essential attribute of God. God is holy, but God does not make of His holiness a barrier between Himself and human beings. He manifested Himself to the people of Israel, and transformed Israel into God's people, and consequently into a holy nation.

'Juan Teodoro Mueller, Doctrina Cristiana (Saint Louis, MO: Casa Publicadora Concordia, 1948), 1:4 (translation mine). 
For you are a people holy to the LORD your God. The LORD your God has chosen you out of all the peoples on the face of the earth to be his people, his treasured possession. (Deuteronomy $7: 6$ )

On the other hand, as we have seen,' secular people consider religion mere emotion or superstition. The aspect of religion that one must emphasize with secular people is that of an encounter and relationship with the living God of the Bible.

As we have seen, ${ }^{2}$ secular people are inclined to think that institutionalized religion destroys human freedom and that God limits their development.

It is also very important to emphasize that an encounter, a relationship, with God, does not limit, but on the contrary enlarges the horizon of human life and creates possibilities which were previously not thinkable.

When God enters in the life of human beings, a new vision of reality appears in them. Life is no longer limited to this world, but becomes a segment of an infinite time. Death is not the end of human existence, but only a limited interruption until the resurrection and new eternal life in the Kingdom of God. Those who will rise again will become citizens of "the heaven" (Phil 3:20).

${ }^{1}$ See pp. 124-125 above.

${ }^{2}$ See p. 126 above. 
Helping Secular People to Recover

a Sense of the Divine

The elementary and unconscious religious feeling proper to every human being has largely disappeared from the consciousness of many Western people. A new forma mentis has developed. Not only do people doubt the existence of God, and this is understandable because God (Deus absconditus, Isa 45:15) hides himself, they also consider God practically useless. They feel that it makes no difference to human Iives whether God exists or not.

It is necessary to help people to recover a sense of the divine--a realization that God is of vital importance to them. They must also understand that if God is eliminated, the dignity of human beings is undercut. If human beings are the result of evolution from animals and not creatures of God, there is no difference between them and animals. They are reduced to the level of irrational beasts.

It is important to show secular people that human beings were created in the "image of God" (Gen 1:27). It is the image of God in us and our relationship with Him that makes us superior to irrational beasts.

\section{God, the covenant, and God's People}

In the Bible there are three central concepts: יהוה 


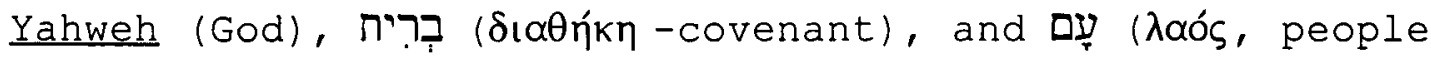
of God).

The Old and New Testaments are theocentric. Gerhard Hasel rightly observes that Old Testament scholars put God in the center.

It is highly significant that virtually all of these suggestions have as their common denominator an aspect of God and/or his activity for the world or man. This inadvertently points to the fact that the OT is in its essence theocentric just as the NT is christocentric.

Walther Eichrodt notes that God made Himself known to Israel through a covenant, which is a union between Yahweh and Israel.

The covenant--union between Yahweh and Israel is an original element in all sources. . . This is still true even of those passages where the word בִּריח has disappeared altogether. ${ }^{2}$

However, according to Von Rad, it is better to consider the relationship between God and the people of Israel as an ellipse rather than a circle. In this ellipse there are two foci: God and His people.

If we take seriously the sentence that Yahweh has chosen Israel and not the contrary, then it will be understood how the religious thought of this people must not be compared to a circle with a center-God-,

${ }^{1}$ Gerhard Hasel, old Testament Theology: Basic Issues in the Current Debate (Grand Rapids, MI: William B. Eerdmans, 1982), 139, 140 .

2Walther Eichrodt, Theology of the old Testament, 2
vols. (Philadelphia: Westminster Press, 1961), 1:36. 
but rather to an ellipse with two foci--God and people. ${ }^{1}$

Von Rad also recognizes that "the covenant with Abraham and the covenant with Moses are now connected with one another and with the whole course of the saving history from Genesis to Joshua."2

Scholars recognize the universality of the covenant. o. Palmer Robertson affirms that "the extent of divine covenants reaches from the beginning of the world to the end of the age." 3

"This is the covenant (ברךרית) I will make with the house of Israel after that time," declares the LORD( ידוה") "I will put my law in their minds and write it on their hearts. I will be their God (אים?), and they will be my people (עָ )." (Jer 31:33)

In this chapter we consider a way of presenting God to secular people. In chapters 10 and 11 the covenant and the people of God are examined.

\section{Yahweh Is One}

The Hebrew people have always confessed that God is one. Through the Shema, a liturgical Jewish prayer, Israel

${ }^{1}$ Gerhard von Rad, Estudios sobre el Antiguo Testamento (Salamanca: Ediciones Sigueme, 1982), 302 (translation mine).

${ }^{2}$ Gerhard von Rad, old Testament Theology (New York: Harper \& Brothers Publishers, 1962), 133.

${ }^{3} \mathrm{O}$. Palmer Robertson, The Christ of the Covenants (Grand Rapids, MI: Baker Book House, 1980), 25. 
even today expresses its faith in and love of one God. : אֶ

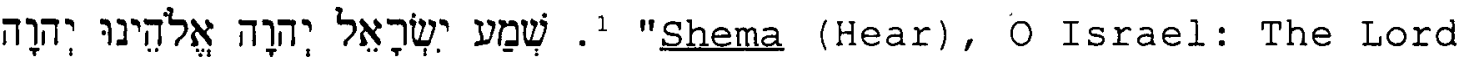
(Yahweh) our God, the Lord (Yahweh) is one" (Deut 6:4).

This statement. . . became the basic formula of absolute monotheism. "This means that the belief that God is One is no longer simply something appertaining to religion, but has also become a part of the theology and metaphysics, a most valuable and vital element in the sum of human knowledge."

When a teacher of the law asked Jesus, "Of all the commandments, which is the most important?" he repeated the Shema: 'Hear, O Israel, the Lord our God, the Lord is one" (Mark 12:29).

Yahweh is one. He is radically different, not only from the gods of the ancient pagan religions, but also from the many representations that people today make of the deity.

The image that people have formed of Him is often different from that of the Bible. Many make gods in their own "image and likeness." These gods are projections of their own personality, as Feuerbach warned. One could say to such persons: "Tell me who is your god and I will tell you who you are!" There are greedy, violent, lustful,

\footnotetext{
${ }^{1}$ The Hebrew Old Testament quoted in this dissertation is the "Biblia Hebraica Stuttgartensia."
}

2Eichrodt, Theology of The Old Testament, 226. 
thieving gods.

Many times humans transfer their passions and power to the things that they revere, and transform them into idols which they may worship.

God, as the supreme value and goal, is not man, the state, an institution, nature, power, possession, sexual powers, or any artifact made by man. . . If the idol is the alienated manifestation of man's own powers, and if the way to be in touch with these powers is a submissive attachment to the idol, it follows that idolatry is necessarily incompatible with freedom and independence. . . God in the Bible and in later tradition allows man to be free; he reveals to him the goal of human life, the road by which he can reach this goal; but he does not force him to go in either direction. . . Idolatry, by its nature, demands submission--the worship of God, or on the other hand, independence. ${ }^{1}$

Generally, secular people do not accept God as He is presented. ${ }^{2}$ They also consider a worship of mere praise or fervor to be a falling back into the obscurantism of an age in which humankind was not mature. According to them, human beings no longer need to ask for divine mercy, but for recognition of human dignity and of their role in collaborating to bring a better life on earth.

Can secular people be shown that a human being naturally tends to be a worshiper. If one does not worship the true God, there is the danger that anything may be

${ }^{1}$ Erich Fromm, You Shall Be Gods (New York: Holt, Rinehart and Winston, 1966), 43-47.

${ }^{2}$ See pp. 122-123 above. 
transformed into an idol and worshiped. Idolatry entails submission and slavery, which is very difficult to surmount. God through Christ sets people free.

Jesus replied, "I tell you the truth, everyone who sins is a slave to sin. Now a slave has no permanent place in the family, but a son belongs to it forever. So if the Son sets you free, you will be free indeed." (John $8: 34-36$ )

It is important to present God correctly in order to help secular people form a true image of God, and to establish a right relationship with Him. Finally, they must realize that knowing something about God does not mean knowing God. The Bible presents God as the Creator, as the Father, who reveals Himself to His sons and loves all human beings--"the evil and the good, the righteous and the unrighteous" (Matt 5:45)--and wishes to establish a friendly relationship with them.

\section{Yahweh, the creator}

The Bible presents God as the Creator of all that is. This is the most fundamental distinction between Yahweh and other deities. Yahweh, who made the heavens and earth, is the true, living, and eternal God. The gods who did not make the heavens and the earth will perish.

But the LORD is the true God; he is the living God, the eternal King. . . Tell them this: These gods, who did not make the heavens and the earth, will perish from the earth and from under the heavens. But God made the earth by his power; he founded the world by his wisdom 
and stretched out the heavens by his understanding. (Jer 10:10-12)

If secular people understand that God is the Creator, their faith acquires concreteness. They learn to relate religious faith to physical reality and to see God through created reality. A starred heaven, a leafy wood, a clear river, and many other beauties of creation will begin to speak to them of the Creator.

Generally, when the doctrine of creation is presented to secular people they make many objections. The information on this subject received in state schools is contrary to every supernatural explanation of nature. The story of creation is considered an out-of-date doctrine that only uneducated persons can accept.

The communicator must correctly understand the biblical story of creation and ought to be prepared to clearly answer the objections that secular people make. Some people betray the real meaning of the Bible by trying to make the Bible say what it does not.

\section{Two Different Conservative \\ Interpretations of Gen 1}

SDAs have always believed in creation ex nihilo, but they have been divided about the interpretation of the first chapter of Genesis.

SDA's. . have generally taken for granted that it 
was on the first day of Creation week that He brought into existence the matter that composed the earth and that He proceeded immediately with the work of the six days. However, almost from the first, some SDA's have allowed that the Genesis account can be understood to mean that God spoke into existence the substance of the earth sometime prior to the events of the six literal days of creation. ${ }^{1}$

There are two conservative interpretations of the

biblical story of creation. Some assume that the earth, moon, and stars are only a few thousand years old and that the radiometric data observed today are the result of the earth being created with apparent age. Others assume that the activities of Creation week involved large amounts of elementary inorganic matter that was previously created some billions of years ago.

A conservative Christian model would start "In the beginning God . . ." . . . chose to create the universe, the earth, and all its inhabitants within six literal 24-hour days. . . All of these phenomena are assumed to have occurred within the past few thousand years. A more moderate yet still conservative Christian model would divide God's creative accomplishments into two separate events. First was the creation of the primordial nonliving matter of the earth and its solar system. . . . Sometime later after this primordial creation, God then chose to create all of the living systems within six literal 24 -hour days. ${ }^{2}$ The individuals who accept the first approach believe

'SDA Encyclopedia, s. v. "Creation," 1:417. Hagerstown, MD: Review and Herald, 1996.

${ }^{2} \mathrm{Clyde} \mathrm{L}$. Webster, Jr., The Earth (Washsington, DC: Office of Education, North American Division, General Conference of Seventh-day Adventists, 1989), $24,25$. 
that the biblical interpretation of Creation does not allow for a billion-year age for the inorganic matter of earth. They assume that the long-term radiometric features were introduced as apparent age into the inorganic matter in a recent creation.

This approach carries some objectionable implications. If the sun, moon, and stars were created on day four about 10,000 years ago, then God also created light waves in transit as if coming from stars millions of light-years away. The stars also had to be created in various stages of maturity, from the black holes to the giant red stars to the white dwarfs. In addition, the nova, the supernova such as SN1987A, and other events that seem to have taken place millions of light-years ago really didn't happen.'

The apparent age of the inorganic matter and the various stages of star maturity are regarded as simple manifestations of God's creative powers. However, there are serious objections to this view.

The creation of light waves seemingly in transit for millions of years and carrying evidence of the supernova that actually did not take place are illusions. These illusions are objectionable because they can imply that God is dishonest. Why should He create evidence for events that did not occur? Or why should He find it necessary to change the laws governing the speed of light? ${ }^{2}$

These objections can be overcome with a second approach. Attentive exegesis of the text will avoid an inadequate presentation of biblical thought.

\footnotetext{
${ }^{1}$ Ibid. , 41.

${ }^{2}$ Ibid., 41, 42 .
} 


\section{An Exegesis of the Biblical Story of Creation}

The biblical story of the creation, found in Gen 1:1 to 2:1-3, can be divided into three parts:

1. Gen 1:1 presents the creation of the "heavens and earth." Gen 1:2 describes the situation in which the earth was when God began His action.

2. Gen 1:3-10 outlines the preparation of planet Earth to receive life. Gen 1:11-31 sketches the formation of vegetal, animal, and human life.

3. Gen 2:1-3 is a description of the institution of the Sabbath as the sacred day of God and memorial of creation. The first part is formed by two verses, which must be examined word by word. The Hebrew text of Gen 1:1 is the following:

1 the earth and the heavens ** God created In beginning

The story of Genesis begins with the words: in

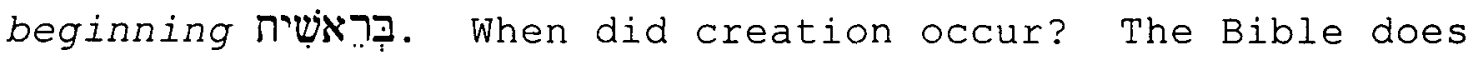
not answer this question or present the date of creation.

Not only it is impossible to determine the date of the creation of "the heavens and the earth," but it is also not possible to establish the date when God created life (in its three forms: vegetable, animal, and human) upon the 
preexistent planet Earth.

Some people have tried to trace a chronology by the patriarchal genealogies, but there are substantial differences in the various versions of the Bible and no one knows if they are complete. The SDA Bible Commentary recognizes that the date of Creation is not known.

Those who attempt to trace Bible chronology from the creation to the Exodus by the patriarchal lists, the Genesis narratives . . must assume that the patriarchal lists are complete. . . However, this volume assigns no dates to the period before Abraham. ${ }^{1}$

According to Webster,

the Bible exists in slightly different versions, which give different ages for patriarchs. The total time since Creation varies among these versions from about 6,000 years to 7,700 years. ${ }^{2}$

According to calculations made on the biblical

genealogies reported in the Masoretic version of the Bible, the date of creation would be 4179 B.C.; those reported in the Samaritan version, 4420 B.C.; those reported in the Septuagint version, 5665 B.C. For these discordances and for other possible gaps in the patriarchal lists, it is impossible to establish a date for when God organized life on the planet Earth according to the Bible. It is necessary

"Date of Creation Not Known," SDA Bible Commentary, ed. F. D. Nichol (Washington, DC: Review and Herald Pub. Assn., 1953-57), 1:195.

${ }^{2}$ Webster, The Earth, 32. 
to remember that the Bible presents genealogies and not chronologies. What did God make in the beginning? God

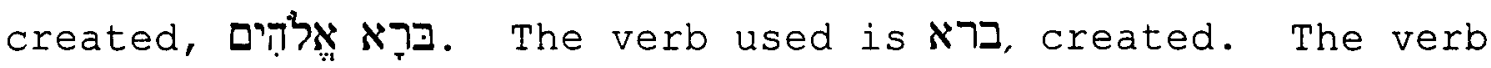
ברא is a verb that refers only to God.

The scope of the use of the verb bara' is greatly limited. It is used exclusively to denote divine creation and appears predominantly in the qal in the OT. . . . As a special theological term bara' is used to express clearly the incomparability of the creative work of God in contrast to all secondary products and likeness made from already existing material by man. ${ }^{1}$

The SDA Bible Commentary clearly shows the difference between two Hebrew verbs: עשואה and It is important to observe that in Gen 1:1 there is the verb ברא and in Gen

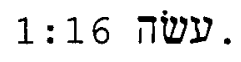

The verb "to create" is from the Heb. bara", which in the form here used describes an activity of God, never of men. God creates "the wind" (Amos 4:13), "a clean heart" (Ps. 51:10), and "new heavens and a new earth" (Isa. 65:17). The Hebrew words that we translate "to make," 'asah, "to form," yasar, and others, frequently (but not exclusively) used in connection with human activity, imply preexisting matter. ${ }^{2}$

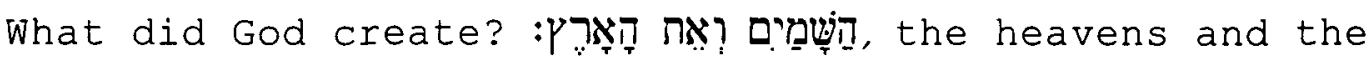
earth. This expression can mean the universe, as in the

${ }^{1}$ Theological Dictionary of the old Testament, ed. G. Johannes Botterweck and Helmer Ringgren, (Grand Rapids, MI: William Eerdmans, 1975), s.v. "bara," 2:246.

"In the Beginning," SDA Bible Commentary, ed. F. D. Nichol (Washington, DC: Review and Herald Pub. Assn., 195357), $1: 208$. 
case of Deut 30: 19, where God calls "heaven and earth as witness against" the people of Israel.

The second verse of Gen 1 in the Hebrew text is the following:

רְדָאָרָץ and-darkness and-empty formless was now-the-earth

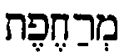

hovering

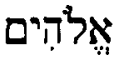

God
ำก and-spirit-of

$$
\text { חזָהום }
$$

פדירני על-

$$
\begin{aligned}
& \text { הַפְּי. } \\
& \text { the-waters surface-of } \\
& \text { עַ } \\
& \text { จา }
\end{aligned}
$$$$
\text { deep }
$$$$
\text { surface-of over }
$$

Gen 1:2 describes the conditions of the Earth when God began to organize the planet in order to receive biological life. The words וָ וָבזה indicate that the Earth was deserted, empty, Iifeless, but not chaotic. This approach assumes that elementary inorganic "matter" existed on Planet Earth before the creation of life there.

Verse 1 identifies God as Creator regardless of when the creation process took place. Verse 2 seems to identify the earth before the Creation week as formless, i.e., no specific organization, and empty, i.e., no inhabitants. . . . In addition to the above, one can add the fact that there is no reference in the Scriptures within the Creation week that addresses the creation of water or the mineral components of dry land. The only reference made to their creation is "in the beginning." It seems possible then that the elementary inorganic matter is not bound by a limited age as is the living matter. . . This approach also strongly suggests that the radiometric age assigned to the inorganic minerals associated with a fossil is more 
a reflection of the characteristics of the source material than an indication of the age of the fossil. Conflicts between scientific and biblical interpretations are minimized with this approach. ${ }^{1}$ Another element is found in vs. 2: the darkness, which was upon the deep.

The "deep" from a root "to roar," "to rage," is frequently applied to the raging waters, the roaring waves, or the food, and hence the depths of the sea (Ps. 42:7; Ex. 15:5; Deut. 8:7; Job 28:14; 38:16). ${ }^{2}$

In the beginning there was no light on Earth. Its surface was covered by dense darkness and the Spirit of God was "hovering over the surface of the waters." In the description of creation, the biblical writer imagines being on Earth, observing all that was happening. After describing the situation he notes eight works made by God. The story is divided into two parts. In the first three days God prepared the habitat; in the next three, the habitants.

And God said, "Let there be light," and there was light. God saw that the light was good, and he separated the light from the darkness. God called the light "day," and the darkness he called "night." And there was evening, and there was morning the first day. (Gen 1:3-5)

On the first day God made the light shine on the

${ }^{1}$ Webster, The Earth, 42, 43.

"Darkness Was upon the Face of the Deep," SDA Bible Commentary, ed. F. D. Nichol (Washington, DC: Review and Herald Pub. Assn., 1953-57), 1:209. 
surface of the Earth. From what source did the light come? Surely this light did not originate directly from God. Since one side of the planet was illuminated and the other remained in obscurity, it is impossible to think that the light originating in the presence of God illuminated only one side of the planet. God is present everywhere.

On the other hand, to think that God first created a source of light to be replaced by the sun two days later is a confused and complicated hypothesis. It is simpler to think that the light came from the sun, but on the first three days it was only possible to observe the light of the sun, such as today occurs when the sun is obscured behind the clouds. When there are two hypotheses, one simpler and the other more complex, it is better to choose the first, the simpler. This is the application of the principle of the philosopher William of Occam (Occam's Razor): Entities are not to be multiplied except as may be necessary. ${ }^{1}$

In addition, the biblical writer clearly describes effects that only the light of the sun can produce.

As soon as the solar light arrived on the surface of the Earth, there were the day, ai, the night, לִיָ the evening, עִרֶב, and the morning, בקר , following one after the

\footnotetext{
${ }^{1}$ Fuller, A History of Philosophy, 419.
} 
other. It is clear that the Earth was rotating on its axis and the light of the sun was illuminating the surface of the Earth.

The literal statement "evening was [with the following hours of the night], and morning was [with the succeeding hours of the day], day one" is clearly a description of an astronomical day, that is, a day of 24 hours' duration. $^{1}$

On the second day God made the firmament, the atmosphere.

No life is possible without air. Plants need it as well as living creatures. Without the atmosphere our earth would be lifeless like the moon, tremendously hot in that part which is exposed to the sun and extremely cold in other sections. ${ }^{2}$

On the third day, God made the dry land and vegetation. God made the seed-bearing plants and the trees that bear fruit with seed, למ̣ינו, according to their various kinds. The מינ, "kind", created by God does not necessarily coincide with the modern species. It can be considered wider than these. Within the "kind" there can be limited genetic variation.

On the fourth day the "luminaries" appear.

"The Evening and the Morning Were the First Day," SDA Bible Commentary, ed. F. D. Nichol (Washington, DC: Review and Herald Pub. Assn., 1953-57), 1:210.

"God Called the Firmament Heaven," SDA Bible Commentary, ed. F. D. Nichol (Washington, DC: Review and Herald Pub. Assn., 1953-57), 1: 211. 
And God said, "Let there be lights in the expanse of the sky to separate the day from the night, and let them serve as signs to mark seasons and days and years, and let them be lights in the expanse of the sky to give light on the earth. And it was so. God made (שעיר) two great lights--the greater light to govern the day and the lesser light to govern the night. He also made the stars. God set them in the expanse of the sky to give light on the earth, to govern the day and the night, and to separate light from darkness. And God saw that it was good. And there was evening, and there was morning--the fourth day. (Gen 1:14-19)

What happened on the fourth day? It is important to observe that the biblical writer uses the verb עש ע, to make, and not the verb ברא, to create. On the fourth day, the heavenly bodies could be seen from the surface of the Earth. They help humans to mark seasons, days, and years.

The days and years are fixed by the movement of the earth in relation to the sun, which in conjunction with that of the moon has provided men of all ages with the basis for calendars--lunar, solar, or a combination of both. ${ }^{1}$

They have an influence not only upon human occupations such as agriculture and navigation, but also upon animal and vegetable life, e.g., the breeding times of animals and the migration of birds.

On fifth day, as in the case of the plants, the birds and the fishes were made "after their kinds."

On the sixth day, as on the third, two works were made by God: the formation of the animals which were living on

${ }^{1}$ Ibid., s.v. "For days, and Years," 1:213. 
dry land, and finally the human being, made in the image of God.

The seventh day, the Sabbath, became the memorial of creation--a sign of belonging to God the Creator, for all human beings who would keep it through the centuries.

\section{The Biblical story of Creation and Its Basic Philosophical Thought}

To the problem of the origin of the universe, the Bible has given an original solution: Creation from nothing (creatio ex nihilo). The Bible does not teach the pantheism of Oriental religions, the dualism of Greek philosophy, or materialism or idealism.

The Bible does not identify God with the universe. The universe is not an emanation, but a creation of God. The universe, is not eternal, but it is a reality created by God "in the beginning" (Gen $1: 1$ ).

We do not find in the Bible words equivalent to Greek terms such as matter, chaos, cosmos. God did not use previously existent chaotic matter when he brought the universe into existence. The world is not formed of bad matter and good spirit. God created the world from nothing (ex nihilo) and all that He created is good, very good. The reasoning of Genesis is simple: if you look for the beginning of all things, you must know that God, who does 
not have a beginning and is outside all things, created the universe and gave a beginning to all things.

\section{The Biblical Story of Creation and Science}

The story of Genesis began with the words in beginning God created. In the beginning, in a given moment God created. ${ }^{1}$

Scientists have tried and still try to explain the universe and life without referring to the idea of God. However, they cannot explain the origin of matter/energy, of the universe, of life, and of the phyla. For example, with new scientific discoveries the elementary particles have lost their corporeality.

Atoms are neither things nor objects. . . We might say that atoms are parts of observational situations, parts that have a high explanatory value in the physical analysis of the phenomena involved. . . . On one hand, Heisenberg insisted upon retaining classical language and the notion of physical or material reality. On the other hand, he insisted that quantum physics reveals a level of reality that is definitely non-physical or non-material. ${ }^{2}$

It is impossible to consider particles whose consistency is "ethereal" to be eternal. Thus the origin of these particles must be sought in a different and eternal

${ }^{1}$ Buonfiglio, ¿Ciencia o Dios? (Nirgua, Venezuela: Editorial Universitaria Adventista, 1993), 163-166.

${ }^{2}$ Roy D. Morrison II, Science, Theology and the Transcendental Horizon (Atlanta, GA: Scholars Press, 1994), 240 . 
source--in the Eternal God.

It is also no longer possible to consider the universe eternal. In fact, according to recent discoveries, the history of the universe began at a given moment, at the moment of the explosion of the superatom (according to the theory of the "Big bang") and will finish when (according to the second principle of thermodynamics) ${ }^{1}$ its energy is exhausted. Scientists know nothing of a history preceding the big bang.

According to the famous astronomer, Paolo Maffei, if the universe has been prepared and has a purpose, then human beings are obliged to believe in a God who created the universe, which evolves toward greater "complexity and spiritualization of matter."2

Paul Davies, a famous physicist, states that to speak of a universe that creates itself is meaningless, because the problems still remain. Nobody knows who has produced the mathematical model according to which the universe was elaborated and why we have a certain type of universe and

${ }^{1}$ According to the second principle of thermodynamics, all energy in the universe tends toward a state of inert uniformity (entropy).

${ }^{2}$ Paolo Maffei, L'Universo nel Tempo (Milano: Arnoldo Mondadori, 1982), 357 . 
not another. ${ }^{1}$

Science has not been able to explain the origin of life, because it cannot explain the origin of the genetic code.

Jacques Monod, famous evolutionist biologist, wrote:

The code is meaningless unless translated. The modern cell's translating machinery consists of at least fifty macromolecular components which are themselves coded in DNA; the code cannot be translated otherwise than by products of translation. It is the modern expression of omne vivum ex ovo. When and how did this circle become closed? It is exceedingly difficult to imagine. ${ }^{2}$

The genetic code allows proteins to form following instructions of the nucleic acids, and not vice versa. For the formation of this code it is necessary to think in a Creator that has elaborated it. ${ }^{3}$

Regarding the origin of the phyla, it is important to clarify that there are no proofs for macroevolution (evolution of the phyla), but only for microevolution (modifications produced in individuals of the same species with the formation of new similar species, which belong to the same "kind"). Microevolution is not contrary to the

${ }^{1}$ Paul Davies, La mente di Dio (Milano: Arnoldo Mondadori, 1993), 278, 279.

${ }^{2}$ Jacques Monod, Chance and Necessity (New York: Alfred A. Knopf, 1971), 143.

${ }^{3}$ Buonfiglio, Ciencia o Dios? 199-262. 
teachings of the Bible, because these modifications occur only within the limits of the kinds created by God.'

In short, it is possible to affirm that scientists and, consequently, secular people can adopt only two possible positions in reference to the problem of the origin of physical and biological reality: either an agnostic attitude, according to which one admits one's inability to explain the origin of the universe; or a creationist attitude, according to which one recognizes that God created the universe.

It is important to show secular people that the story presented by Genesis is not a beautiful "tale." Science cannot explain the origin of the universe and of man. There is only one possible explanation: God created the first human couple. There is no other alternative. The agnostic answer ( $I$ do not know) is really not a true alternative because it is not an answer to the problem at all.

Roberto Fondi, an Italian paleontologist of the University of Siena, clearly wrote:

The evolutionists believe that mankind and the anthropoid ape derive from ancestors with common characters who lived in the Cenozoic era; but of such supposed men-beasts never has been found any sure exemplary fossil. In addition the paleontologic documentation that we have does not present that gradual succession from semi-animal forms to actual

${ }^{1}$ Ibid., 313-315. 
human forms that according to evolution would be realized. ${ }^{1}$

It is also important here to underline that Genesis freed Israel from the fears, which the pagan peoples had toward their deities. God is a God who establishes a relationship with human beings. Genesis uses a vivid anthropomorphic image to indicate the relationship between God and the first human beings: "Then the man and his wife heard the sound of the LORD God as he was walking in the garden in the cool of the day" (Gen 3:8).

\section{God Has Spoken}

Secular people know very little of the Bible, and that little is often incorrect. It is necessary to help them to study, to love, and to understand the Bible correctly.

Words are the means by which two persons encounter each other. I speak and another listens to me. Words are the media of communication. Language is a code through which the information one wants to communicate is sent, received, and decoded. In daily and scientific language, information and instructions transmitted are generally impersonal.

Usually an individual hides himself under a mask and does not reveal his true personality. Sometimes two persons

${ }^{1}$ Giuseppe Sermonti and Roberto Fondi, Dopo Darwin (Milano: Rusconi, 1982), 285 (translation mine). 
desire to establish an intimate dialogue. In this case words are the media through which they reveal themselves to one another. However, if people want to reach this level it is necessary that they remove the veil that covers their personality. This is possible only if there is friendship and confidence between the two. Only if a person trusts another, will he open himself.

God, the Deus Absconditus, hides Himself in order to leave man free to make his choices. God does not want to frighten man by His unlimited power. God removes the veil and reveals Himself to human beings who want to communicate with Him. He interrupts His silence and establishes a relationship that saves man and communicates life. The Bible is a medium used by God to communicate with human beings.

Secular people have difficulty in understanding religious language, including biblical language. They are unable to see the difference between the message of the Bible and the language that conveys the message. It is very important to help secular people to learn to separate the biblical message from the language and the cultural forms used by biblical writers.

God is the Author of the Bible, but it was written by men, who expressed the biblical truths in human words. 
The Bible is written by inspired men, but it is not God's mode of thought and expression. It is that of humanity. God, as a writer, is not represented. . . The writers of the Bible were God's penmen, not His pen. Look at the difference. It is not the words of the Bible that are inspired, but the men that were inspired. Inspiration acts not on the man's words or his expressions but on the man himself, who, under the influence of the Holy Ghost, is imbued with thoughts. But the words receive the impress of the individual mind. The divine mind is diffused. The divine mind and will is combined with the human mind and will; thus the utterances of the man are the word of God. ${ }^{1}$

It is extremely important that secular people understand that the language of the Bible is human language, that the writers of the Bible were inspired, not the words and expressions used by them.

Since, however, all human beings are bound by culture, the biblical message is necessarily "embodied" in a particular culture, that is the Hebrew culture.

Christianity arose on Jewish soil; Jesus and the Apostles spoke Aramaic, a language related to Hebrew. - . As the New Testament writings show, they were firmly rooted in the old Testament and lived in its world of images. ${ }^{2}$

In order to understand the language and contents of the Bible, it is necessary to comprehend the Hebrew mentality and culture.

Biblical scholars are quite aware of this and insist

${ }^{1}$ Ellen G. White, Selected Messages (Hagerstown, MD: Review and Herald Publishing Association, 1986), 1:21.

${ }^{2}$ Thorleif Boman, Hebrew Thought Compared with Greek (New York: W. W. Norton \& Company, 1960), 17. 
upon it. We are told that we must become semites mentally and spiritually if we want to appreciate the Bible and not misunderstand it. ${ }^{1}$

If God chose the Hebrew culture through which to reveal Himself, He surely had a good reason. There is a tight relation between the content of a message and the form in which it is communicated.

Christians believe that the Holy spirit not only inspired the writers of the Bible, but also supervised the process through which the books of the Bible were accepted as inspired.

It is interesting to note that only some Hebrew and Christian books were accepted in the biblical canon as books inspired by God. Other religious books written by Hebrews and Christians were not included. This demonstrates clearly that a selection was made.

God acted on the men whom He chose, corrected their culture and preserved them from the culture of the neighboring pagan peoples.

The culture of the Hebrews was not just the product of their environment, but was continuously transformed by God's Word presented to them by the prophets.

God chose Abraham, but brought him out of a

${ }^{1}$ Charles Davis, Theology for Today (New York: Sheed and Ward, 1962), 16, 17 . 
Mesopotamian culture. The Supracultural God, through His continuous interactions, radically changed the life and culture of Abraham, who became the "friend" of God.

God interacted with the Patriarchs, during their seminomadic life, and changed their mentality and culture. The people of Israel in their pilgrimage from Egypt to the Promised Land eliminated all negative cultural elements received from the surrounding peoples.

God continuously sent prophets who disapproved all forms of syncretism between biblical thought and that of the pagans. Idolatry, pagan sexual immorality, corrupt economic and politic practices were condemned by God. Even if the biblical message was expressed in the language and thought forms of Hebrew culture, God took care that His message was never contaminated by the culture and religion of the pagan people.

In the Bible there are many anthropomorphisms-attributions of human characteristics and activities to God-and many anthropopatisms--attributions of human emotions to God.

The Bible uses many images taken from the physical and psychological human world. By means of anthropomorphisms the Bible speaks of hands, mouth, heart, eyes, feet, and the arm of God. God smiles, gets anger, smells, walks, beats, 
etc. By means of anthropopatisms the Bible affirms that God perceives human feelings. He grieves. He feels pain, joy, hatred, etc.

The Hebrew language is poor in abstract concepts and prefers the use of concrete images. Although the anthropomorphisms and anthropopatisms have been effective means to express the vitality and personality of God, it is necessary to recognize the danger of transforming God into a human being.

In Gen 6:6 is written: "The Lord was grieved that he had made man on the earth and his heart was filled with pain." But the same Bible clarifies that God is not a man. "God is not a man, that he should lie, nor a son of man, that he should change his mind" (Num 23:19). "The Father - . does not change like shifting shadows" (Jas 1:17). The prophet Isaiah warned: "'To whom will you compare me? Or who is my equal?' says the Holy One" (Isa 40:25, 26). Thus God is the Author of the Bible, but the language, the cultural forms are of the writers of the Bible.

The Bible points to God as its author; yet it was written by human hands; and in the varied style of its different books it presents the characteristics of the several writers. The truths revealed are all "given by inspiration of God" (2 Timothy 3:16); yet they are expressed in the words of men. The Infinite one by His Holy spirit has shed light into the minds and hearts of His servants. He has given dreams and visions, symbols and figures; and those to whom the truth was thus revealed have themselves embodied the thought in human 
language. ${ }^{1}$

To summarize, the writers of the Bible expressed the truths inspired by God in human language. If the Bible had been written in mathematical language, only a few would have understood. Moreover, mathematical language is limited. Obviously, it is necessary to help secular people make a distinction between human language and the divine message.

\section{God Acts in Human History}

Secular people, much like deists, consider God completely indifferent and unconcerned regarding human affairs. It is necessary to show them that the history of humanity is not understood by the biblical writers as the fruit of chance. God acts in human events (Neh 9:7, 8).

The encounters that took place during the centuries between God and Israel completely changed its existence. The living God acted and freed it from bondage.

The important thing for Israel was not the yearly cycle, which is continuously repeated, but what God has made, makes, and will make in the life of His people and of His sons, according to His promises. Time was not circular, and history is not a repetition of infinite cycles without any future purpose.

${ }^{1}$ Ellen $G$. White, The Great Controversy between Christ and Satan (Oshawa, Ontario, Canada: Pacific Press Publishing Association, 1950), v. 
For the biblical writers, eternity is not the absolute absence of time, but the succession of an infinite series of instants, in which God acts for the benefit of human beings.

In the Bible, time is linear. According to Cullmann, biblical time can be graphically represented as an infinite line, on which two points represent respectively the original creation (point A) and the new creation (point B). Accordingly, the line is divided in three parts: the past age, represented by the part of the line that goes from point A to infinity; the present age (this age, d aỉv oưtos, 2 Cor 4:4), represented by the segment $A B$; and the future age (the age to come, of aíuv $\mu \varepsilon \dot{\lambda} \lambda \omega \nu$, Mat 12:32), represented by the part of the line that goes from point B to infinity. WE HAVE SEEN that the Biblical time line divides into three sections: time before the creation; time from Creation to the Parousia; time after the Parousia. Even in Judaism we find interwoven with this threefold division. ${ }^{1}$

While, the term "the age" (ó aì̀v, saeculum) indicates each of the three divisions of the line of time, the kalpós (momentum) indicates a definite point of time. Only God can fix the dates (momenta, kaıpól) (Acts 1:7) in which He acts in the history of peoples and of individuals. God loves human beings and $\mathrm{He}$ is always ready to help them by

'Oscar Cullmann, Christ and Time (Philadelphia: Westminster Press, 1960), 81. 
intervening in their lives.

As we have seen, it is very important to show secular people that God takes care of human beings. The history of humankind is neither a continuous repetition of infinite cycles nor a set of chaotic events without a determined end to reach. As the Apostle Paul presented the "day when he [God] will judge the world" (Acts 17:31) to the intellectuals of his time, ${ }^{1}$ thus it is necessary to show how

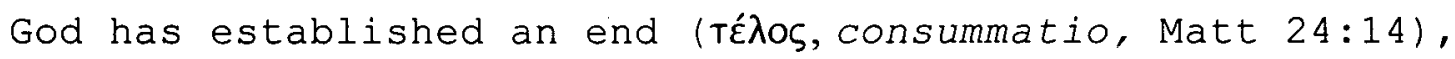
the point $B$, in which He will fulfill His promises creating a "new heaven and new earth, the home of righteousness" (2 Peter 3:13).

God has a plan not only for the whole of humanity, but also for all human beings. He is ready to act in their life and to fulfill their salvation.

\section{God Is Love}

As we have seen, ${ }^{2}$ secular people may refuse to accept God because of the manner in which He is presented to them. It is important to present God in a clear and exact way, so that they can understand the real nature of God. The Apostle Paul wrote:

\footnotetext{
${ }^{1}$ See p. 144 above.

${ }^{2}$ See pp. 122, 123 above.
} 


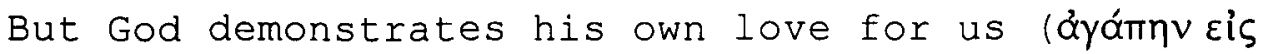
inâs) in this: While we were still sinners, Christ died for us. (Rom 5:8)

The Apostle John expressed the same concept clarifying the real nature of God:

"Dear friends, let us love one another, for love comes from God. Everyone who loves has been born of God and knows God. Whoever does not love does not know God,

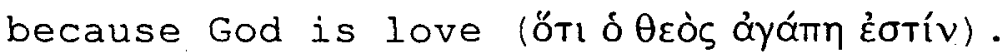

(1 John $4: 7,8$ )

The word used by both Apostles is áyóm what does this Greek word mean? In the Greek language the

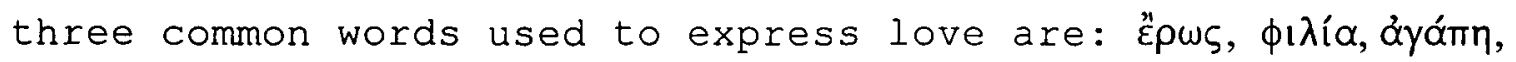
All three have different meanings.

1. "Epws meant a passionate love, an ardent desire and aspiration. It had a particular meaning when used in connection with religious rituals.

What the Greek seeks in eros is intoxication, and this is to him religion. . . Creative eros stands at the heart of the fertility rites, and prostitution flourishes in the temples of the great goddesses, often under oriental influence. . . . But the intoxication sought by the Greek in eros is not necessarily sensual. Already in the Greek mysteries, as so often in mysticism, erotic concepts are spiritualized in many ways as images and symbols for the encounter with the supersensual. ${ }^{1}$

2. Фıגía signified the love of friends for friends. It was a feeling that bears a human countenance. It was not an

${ }^{1}$ Theological Dictionary of the New Testament, ed. Gerhard Kittel (Grand Rapids, MI: Wm. B. Eerdmans, 1964),

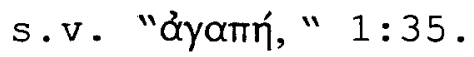


impulse or intoxication that overcame human beings, but something that he may evade.

3. 'Ayárn, agape, which contained nothing of magic, was a love which chose its object freely and gave all on the other's behalf. In contrast, "Epws was a general love seeking satisfaction wherever it could, determined by indefinite impulsion toward an object.

In the old Testament the main word for love is ('ahabhah), which covers some meanings of the three Greek words. It is applied to the love between man and woman and to the feeling of friendship, but it did not contain the meaning of religious erotism.

The root 'ahabh is also used for the relationship between Yahweh and Israel... . and thus indicates complete love which demands all one's energies. ${ }^{1}$

Sometimes the reader who is not an expert can receive the false impression that the Old Testament presented God in a different way from the New Testament. It is important that secular people know that the Bible presents individuals and peoples as they are and not as they ought to be. In their humanity God's people did not always understand the true nature of their God.

When Jesus presented God, He used verses of the old

\footnotetext{
${ }^{1}$ Theological Dictionary of the old Testament, s.v. " 'ahabh," 3:104.
} 
Testament. For example, He answered the question: "Of all

the commandments, which is the most important?" by quoting

the Old Testament:

'The most important one,' answered Jesus, 'is this: Hear, O Israel, the Lord our God, the Lord is one. Love the Lord your God with all your heart and with all your soul and with all your mind and with all your strength.' The second is this: 'Love your neighbor as yourself.' There is no commandment greater than these. (Mark 12: 29-31)

Jesus taught the people that it is necessary to love

their own enemies, as God the Father who is in heaven loves

good and evil persons.

The Old Testament also teaches that is necessary to forgive and love one's enemies.

Do not seek revenge or bear a grudge against one of your people, but love your neighbor as yourself. I am the LORD. (Lev 19:18) 1

The Bible presents God as a God of love, Who revives

the heart of the contrite.

For this is what the high and lofty one says--he who lives forever, whose name is holy: "I live in a high and holy place, but also with him who is contrite and lowly in spirit, to revive the spirit of the lowly and to revive the heart of the contrite." (Isa 57:15)

Only a God who is love, mercy, a God who takes care of human beings, who suffers when they suffer, rejoices when they rejoice, can attract secular people. This is the image of God that biblical communicators must present to others.

${ }^{1}$ See Exod 23:4; Prov 25:21; Lev 19:34. 


\section{Summary}

It is necessary that communicators present a true image of God if they want to help secular people to recover a sense of the divine and establish a correct relationship with God.

Certainly, it is not easy to present a clear idea of the God of the Bible. It is necessary to eliminate all false concepts that are in the mind of secular people, those caused by false philosophical thoughts and those formed by false interpretations of the Bible.

In this chapter we have seen the biblical concepts of religion and of God. We have also examined the biblical text of Gen 1 and suggested how to present God to secular people. In chapters 10 and 11 the covenant and people of God are examined. 
CHAPTER $\mathrm{X}$

HOW TO PRESENT THE COVENANT TO SECULAR PEOPLE

\section{Introduction}

The Bible records the extraordinary experience of a people who, in spite of not having any political importance, had the privilege of establishing an alliance (a covenant) with God--a unique and intimate relationship with Him.

Two thousand years before Christ, God made a plan to build a holy people from nothing. God called Abraham out from his family and people, and established a dialogue with him that, in many forms, continued with the people of Israel. The history of God's people, to whom nobody is a stranger and whom all are invited to join, began with Abraham.

There are many stages in this wonderful experience. In every stage we find the intervention of God (הוה") that is a starting point, and the invitation to the covenant (כָּרִיח)

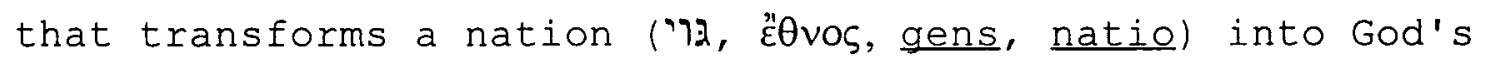

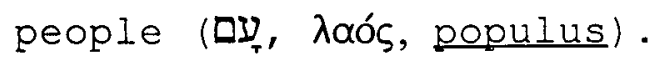

The Bible records the encounters between God and His 
people, in which God invited His people to remember the covenant and to revive their relationship of friendship with Him. God, the Almighty, unreachable to men, was near His people through a constant presence and continuous action. His encounters with human beings are certainly astonishing events of the old Testament.

The characteristic statement of the covenant occurs in

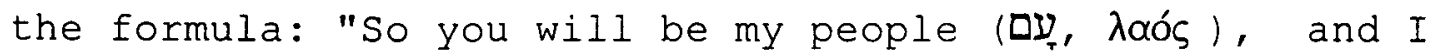
will be your God" (Jer 30:22). This means that God gives Himself to His people and they in turn give themselves to Him and belong to Him. His motive in adopting Israel as His

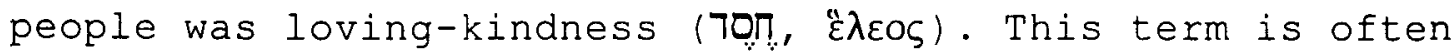
associated with the covenant.

It is important to clarify to secular people the purpose, the meaning, and the characteristics of the covenant, which is the central theme of the Bible. In addition, comprehension of this concept allows secular people to understand the most important part of the biblical message and transcend many of their prejudices against religion.

\section{The Covenant}

The word covenant, כברית, occurs approximately 275 times in the Old Testament. Some parts of the old Testament use 
the term more frequently than others. The importance of this concept does not depend on the presence or frequency of the term covenant. Even if the word is absent, the concept of the covenant is always present in the Bible.

W. E. Albright agreed that the idea of the covenant dominates the entire religious life of Israel and that the idea is present often when the term berit does not occur. . . We cannot understand Israelite religion, political organization, or the institution of the Prophets without recognizing the importance of the "Covenant." 1

The etymology of the Hebrew word I], covenant, is uncertain. The verb כרת, which means "to cut off," "to cut in two," is frequently used with the accusative תִִרי. The expression כרת כִּרִית, "to cut a covenant," may come from the covenant ritual (Gen 15, Jer 34), in which a party passes between animal pieces. There is an allusion to the consequences of disloyalty. If one breaks a covenant, he should be cut in pieces like those animals.

Some scholars have sought the origin of the בִּרִיח outside of Israel. They have noted a possible analogy between the treaties of the Hittite Kings and their vassals and the covenant relationship between Yahweh and Israel. But the primary purpose of these treaties was to

${ }^{1}$ Ralph L. Smith, old Testament Theology (Nashville: Broadman \& Holman Publishers, 1993), 140. 
establish a firm relationship of submission of vassals to the power of suzerains, which certainly was not a friendly relation. Nicholson observed:

Vassals did not as a rule 'love' those who conquered, subdued and dominated them. . . . To tell Israelites that Yahweh 'loves' them in the same way as a suzerain (e. g. Ashurbanipal or Nebuchadnezzar) 'loves' his vassals, and that they are to 'love' Yahweh as vassals love their suzerains would surely have been a bizarre depiction of Yahweh's love of, and commitment to, his people, and of the love and commitment with they were called upon to respond. ${ }^{1}$

As we have seen, ${ }^{2}$ secular people reject the image of God as a severe Monarch who undercuts human freedom. It is necessary to clarify that the covenant is an act of love, which is not imposed compulsorily, but must be received freely. Israel was free to accept or reject the covenant God offered to them.

In addition, the covenant between Yahweh and Israel has a particular juridical meaning that differentiates it from secular covenants.

In $1986 \mathrm{E}$. W. Nicholson published two important works on the covenant (God and His People; "Israelite Religion in the Pre-exilic Period" in $A$ Word in season). He traced the history of covenant studies and argued that the covenant may still be considered the central theme of the old Testament. . . . Covenant makes old Testament religion unique and distinctive not because other religions did not use the idea of

${ }^{1}$ Ernest W. Nicholson, God and His People (Oxford: Clarendod Press, 1986), 79.

${ }^{2}$ See p. 123 above. 
covenant, but because Israel's idea was not based on nature or necessity. God chose Israel freely for no expressed reason, and Israel responded freely to God's offer (God and His People, vii-viii). In 1991

Christoph Barth claimed that "making a covenant" has a legal background. When God chose Abraham, God did not show him an isolated kindness which He might withdraw at His pleasure. He entered into a "lasting and regulated" relationship that could be understood only in legal terms because it was founded on God's justice. The terms sedeqa "justice" and hesed "covenant-love" are part of covenant language. ${ }^{1}$

It is important to clarify to secular people that the covenant of grace (בָרִית) is a unilateral act by which God promises to human beings the forgiveness of their faults, the sanctification of their lives, and the transformation of them as His sons and daughters.

It is also necessary to show the danger of transforming a biblical covenant into a contract in which partners of equal status reach a reciprocal agreement regarding protection and blessings with meritorious works, such as "sacrifices, festivals pilgrimages, fasting and so on." Eichrodt wrote:

As far as the covenant was concerned this meant the externalization of man's relation to God, its transformation into a religion of 'Do ut des' in which the divine gift is bound to reciprocate human performance. This legalistic distortion of the covenant relationship into a commercial arrangement between parties of equal status before the law rendered all intercourse with the deity lifeless and trained men in an irreverent calculation of divine obligations, which made any attitude of trustful surrender

${ }^{1}$ Smith, old Testament Theology, 149, 150. 
impossible. In this way the religious values originally mediated by the covenant were falsified. ${ }^{1}$

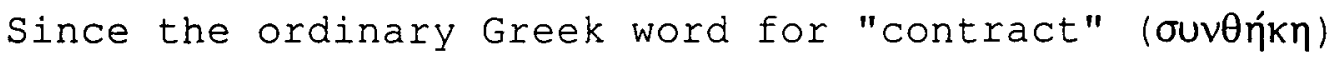
implied the equality of the contracting parties, Greekspeaking Jews preferred $\delta ı \alpha \theta$ ńkn, which means a unilateral disposition of one's own property, a last will, a testament. A contract is a two-sided juridical act, which is perfect only when the will of one partner meets the will of the other and both reach an agreement enforceable by law.

The word בִּרִית quite correctly was translated by the Greek term $\delta ı \alpha \eta \eta ́ n \eta$ and by the Latin term testamentum. The testator expresses his will and writes a testament. The testament is valid only with the death of the testator. The heirs can only accept or reject the testament, they cannot change the terms in which it is redacted.

By the covenant (בְּרִית) God wanted to redeem the people of Israel and transform them in a holy nation. Israel was to avoid every form of idolatry and immoral habit of pagan peoples. God gave them a new lifestyle, a new vision, and a new mission. Israel was to reveal God's character, to make known His love for human beings, to announce His plan of salvation for all human beings and to offer them the opportunity to change their life.

\footnotetext{
${ }^{1}$ Eichrodt, Theology of the Old Testament, 1:47.
} 
The Bible presents a series of related covenants. ${ }^{1}$ However, the old Testament always speaks of the one and only covenant. The covenant is one even if the Bible records several occasions on which God's covenant was renewed.

The Old Testament knows nothing about covenants in the plural. The word is always found in the singular. There is constant reference to one covenant designated by God as "my covenant, "his covenant," phrases that occur throughout the Bible. ${ }^{2}$

Some general characteristics of the covenant must be examined in order to clarify how to present the covenant to secular people.

We have seen that a characteristic of secular people is their concern for meaning regarding both the world and human life. ${ }^{3}$

Some secular people think that an initial chaos was successively ordered according to mathematical laws. The universe then has a mechanical and cyclical development that is repeated ad infinitum. In this case there is no prospect of a future. This universe has no meaning.

As we have seen, ${ }^{4}$ according to the biblical story of

${ }^{1}$ Cf. Robertson, The Christ of the Covenants, 27-52.

${ }^{2}$ Edward Heppenstall, "The Covenants and the Law," in our Firm Foundation (Washington, DC: Review and Herald, 1953), 442 .

${ }^{3}$ See pp. 127 above.

${ }^{4}$ See pp. 196, 197 above. 
creation, at the origin of the universe there was no chaos, but the initiative of God who makes a free choice. He organized the planet Earth to prepare it to receive life and created persons capable of sustaining a relationship with Him. It was a choice of a God who loves and continues to offer His love even if the other does not respond.

God offered man a perfect world and assured him of His providential support but permitted the inventiveness of humans to find a manner of perfect adjustment to the world. Genesis also tells the tragic situation in which human beings found themselves after their fall. God realized the rejection of the first human beings and indicated the consequences of their rejection. Women's pain would be increased in childbearing. The ground would produce thorns and thistles. By the sweat of their brow men would work for their food until death, for they were dust and to dust they would return (Gen 3:19). These were the consequences of their faults.

The breakdown of friendship with God became the rejection of other friendships and left a mark on human nature. Negative tendencies and inclinations are transmitted from one generation to another.

But God is a God of mercy, ready to forgive the guilt of those who recognize their faults and are ready to change. 
God continued to love human beings even after their fault and answered their rejection with the offering of $\mathrm{His}$ liberating intervention.

As we have seen, ${ }^{1}$ some secular people think that God limits their freedom. It is important to clarify that God does not hinder human freedom, instead He helps human beings to overcome their hereditary tendencies and to recover a lost freedom.

This is the message that is found in the words directed to the serpent and that became ever clearer during the history of the people of Israel and when the Messiah came.

And I will put enmity between you and the woman, between your offspring and hers; he will crush your head, and you will strike his heel. (Gen 3:15)

G. von Rad and other old Testament scholars consider the narrative of Gen 3 to be a myth. On this view the natural animosity between men and snakes would push the ancients to invent the story of the curse of this beautiful beast to provide answers to perplexing questions about life. The Bible clearly speaks of an "ancient serpent called the devil, or Satan" (Rev 12:9). Nothing hinders us from thinking that Satan used a serpent as the medium by which he could astonish and establish contact with the woman. Even in modern times there have been cases in which animals have

\footnotetext{
${ }^{1}$ See pp. 121, 123 above.
} 
been used as mediums in spiritistic meetings.

In Gen 3:15 God announces that there will be enmity between the serpent, Satan, and the woman (womankind), and between the offspring of Satan and that of the woman.

Gen 4:8 records that Cain killed his brother Abel. John wrote that Cain "belonged to the evil one" (1 John $3: 12)$.

Einally, Gen 3:15 indicates that "he will crush the head of the serpent," he will destroy Satan. Who is this "he"?

Since the Greek word for "seed" ( $\sigma \pi \varepsilon \varepsilon \mu \alpha)$ is neuter, it would have been quite appropriate that it be followed by the neuter pronoun "it" (aủTó). . . . The septuagint translators chose a distinctively masculine "he"

(aủTós). "He," the seed of the woman, shall crush the head of the serpent. . . . In Psalm 110. . vigorous imagery describes the triumph of the coming messianic Lord. Triumphantly he will "smash the head" of his enemies in a broad land (Ps 110:6). . . Ultimately, the promised seed of the woman did come. He entered into mortal conflict with Satan. Through suffering on his cross, the wound of Satan, he "despoiled the principalities and powers" and "made a show of them openly," triumphing over them in it (Col 2:14, 15). ${ }^{2}$

Because of the mercy of God, the covenant would not be dissolved in the event of disobedience on the part of the people. It was necessary to sacrifice animals. The blood of the victims reestablished the covenant broken by the fault. In Lev 2:13 the salt of offerings was called "salt

${ }^{1}$ Robertson, The Christ of the covenants, 100-102. 


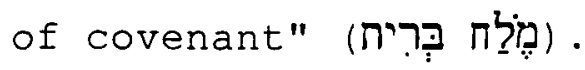

The animals sacrificed symbolized Jesus, "the lamb of God, who takes away the sin of the world" (John 1:29). God realized His plan of salvation in the death and resurrection of His son. Jesus' dying destroyed death, His rising restored life.

"God was reconciling the world to himself in Christ,"

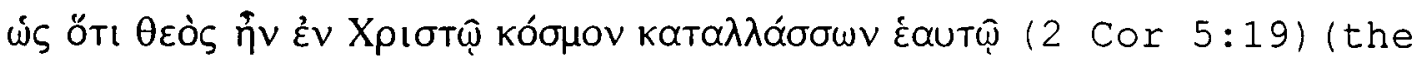

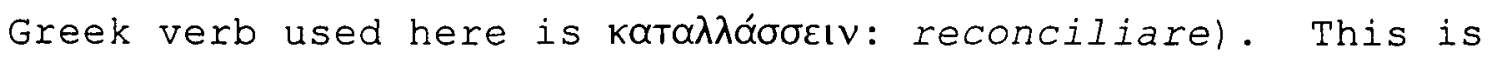

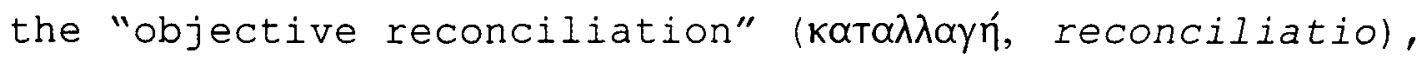
which God proclaimed and offered to all human beings by the resurrection of Christ.

By faith in the atonement, fulfilled by Christ on the cross, objective reconciliation becomes subjective reconciliation every time a human being asks for and receives the forgiveness of his/her faults.

The Gospel is precisely the Word of reconciliation. "God has committed to us the message of reconciliation (Tóv

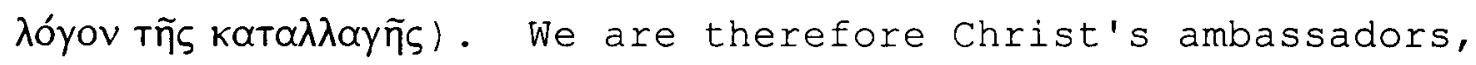
as though God were making his appeal through us. We implore you on Christ's behalf: Be reconciled to God" (2 Cor 5:1920). God has given Christians the "ministry of

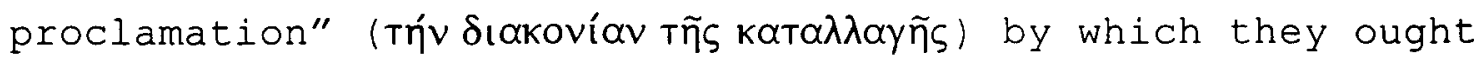


to announce that Christ has accomplished the covenant on the Cross, that He is applying the atonement to humankind by His heavenly ministry, and that He will completely fulfill it when He comes again and introduces God's people to the "new heavens and a new earth."

As we have seen, secular people many times reject religion because the doctrines are presented in a mystical way. That is why it is important to present the doctrines of atonement, justification, and sanctification in a clear and rational way. "Sin" is not a fluid that is neutralized by another fluid. There is nothing of magic in the Bible. These doctrines must not be presented in an irrational or abstract manner. Sin is a reality in the life of every human being.

The Gospel is the Good News that God has already fulfilled His promise. The Messiah came, died, and provided salvation for all human beings. To preach the biblical message means to announce that God has already reconciled human beings to Himself through Christ. Today the biblical message is an invitation to all human beings to establish a pact, a personal relationship with God by baptism, to become sons of God and members of God's people. Therefore, if anyone is in Christ, he is a new

${ }^{1}$ See pp. 124-125 above. 
creation; the old has gone, the new has come! All this is from God, who reconciled us to himself through

Christ and gave us the ministry of reconciliation: that God was reconciling the world to himself in Christ, not counting men's sins against them. And he has committed to us the message of reconciliation. We are therefore Christ's ambassadors, as though God were making his appeal through us. We implore you on Christ's behalf: Be reconciled to God. God made him who had no sin to be sin for us, so that in him we might become the righteousness of God. (2 Cor 5: 17-21)

Christ is the fulfillment of the covenant (ברִיחית). In Christ, human beings must be born again.

It is necessary to clarify what "to be born again" means to secular people, who have incorrect ideas about the action of God in the life of human beings. The Holy Spirit convicts men of guilt (John 16:7-8), teaches them about Jesus (John 16:15), and makes them born again (John 3:5-8).

The communicator must explain that God does not Iimit human freedom. God does not narrow human life. On the contrary, He helps improve our freedom and enlarges the perspective of life.

Generally, an individual thinks himself free when he is able to make a decision; i.e., to refuse or to choose to do something. Free will is the capacity to decide according to one's knowledge, feelings, and capacities.

However, all human beings have hereditary and environmental tendencies which limit their freedom. Paul said: "As it is, it is no longer I myself who do it, but it 
is sin living in me" (Rom 7:17). He knew that he was not free, because the negative hereditary and environmental tendencies (that he called sin) forced him to make decisions that he did not want to. Even when he understood what was right and desired to do it, he was incapable of doing it because the negative tendencies of his personality were stronger than his desire to act correctiy.

Paul continued: "Thanks be to God--through Jesus Christ our Lord. . . Because through Christ Jesus the law of the Spirit of life set me free from the law of sin and death" (Rom $7: 25 ; 8: 2)$.

Jesus makes human beings free (really free). How? Jesus, who lived without fault (John 8:46; Heb 9:14), is the unique model of the true, free, ideal human being. Every individual who wants to change his nature must structure his personality according to the ideal new model. He must put off "the old man," the "old self, which is being corrupted by its deceitful desires" (Eph 4:22). He has to put on the "new man," "the new self, created to be like God in true righteousness and holiness" (Eph 4: 24) and to attain "to the whole measure of the fullness of Christ" (Eph 4:13).

Here Paul proposes a dynamic concept of the personality. Personality is not static. Humans can choose between two possible directions: "according to the sinful 


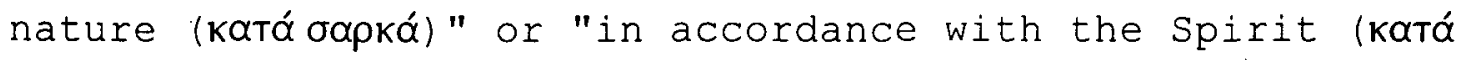
$\pi v \varepsilon \tilde{u} \mu \alpha)$."

Those who live according to the sinful nature (katá барка́) have their minds set on what that nature desires; but those who live in accordance with the

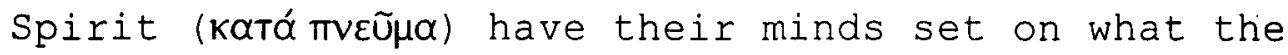
Spirit desires. (Rom 8:5)

In Gal 5:13 Paul clarifies that those who are called by Christ are called to be free and in Gal 3:16-26 shows the

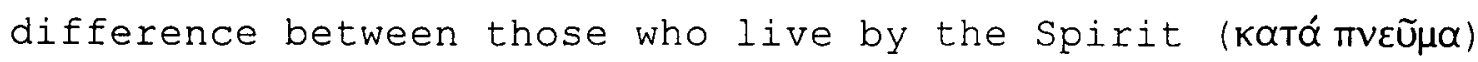

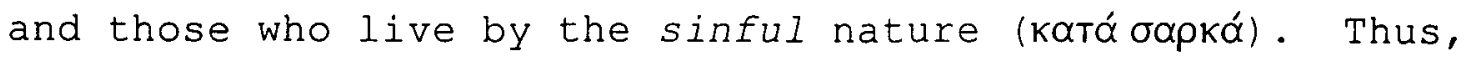
there are two categories of human beings: the carnal human being ( 1 Cor 3:3, oapkıkoí) and spiritual human beings ( 1 Cor $2: 15, \pi v \varepsilon \cup \mu \alpha+$ Tikoí ) .

The ideal human being proposed by the Bible is one who develops all one's faculties (physical, psychic, and spiritual). Asceticism, which is based on Greek ontological dualism according to which the human being is formed by a material body and spiritual soul, considered negatively the physical faculties of human beings. The ascetic life is a life that requires the continuous punishment of the body in order to release the soul from the bondage of the body and permit its union with the divine. On the contrary, the Bible teaches that it is necessary to develop and improve the physical faculties.

An individual can develop or reduce his faculties. Some 
faculties can become atrophied. There is a harmonious development of the personality only when all faculties are developed and tend to the affirmation and development of the individual. Only a relationship with God can help the individual to overcome his negative tendencies and to develop a free personality.

Clearly, while negative tendencies are transmitted genetically (Rom 5:12), the "new birth" is a work of the Holy spirit and can be verified only by the results produced by the Spirit (John $3: 6-8$ ).

It is interesting to observe that scientific discoveries confirm the possibility that a human being can change his or her personality.

\section{Some Einal Considerations}

As we have seen, ${ }^{1}$ secular people may have feelings of guilt, but they do not seek forgiveness in God, because they have a distorted image of God. This is why it is necessary to explain and clarify the exact concept of the covenant.

secular people need a clear orientation and a model, ${ }^{2}$ therefore communicators must present Jesus as the ideal model. In this chapter we have seen that is necessary to

${ }^{1}$ See p. 122 above.

${ }^{2}$ See p. 115 above. 
avoid the impression that there is something of magic in the atonement. Sin is a reality in the life of human beings and not a magic fluid that contaminates human beings. God transforms human beings, reproducing the life of Jesus in their lives.

His invitation is neither a dream nor a projection of their desires, but a pressing, vivid, and real calling by a God who loves and wants to free them. God wants to establish a communion with them, which entails a change in the lives of the people. They must become a new people, with a new worldview and a mission to fulfill. The God of the Bible is a God who takes the initiative, calls people, helps them to acquire a consciousness of the situation of bondage, and frees them.

However, the freedom offered by God is not a freedom from but freedom for. God does not want individualists, who want to be free from any responsibility toward others, but free individuals who pursue their development in a living community of free human beings and live their freedom in order to help others to become free.

In chapter 11 the people of God, which is the community of free human beings, are considered. 
CHAPTER XI

THE CHURCH AS THE PEOPLE OF GOD

\section{Introduction}

In Christ, human beings are born again and become sons of God and members of His people (ע, גaós, populus). In the New Testament the church is the "people of God" (2 Pet $2: 9-10)$

Adhesion to the message of Christ must be a free act of faith. A person becomes Christian when he accepts christ in his lifestyle in an autonomous and free way.

It is important to prepare the church that will receive secular people. According to the biblical conception it must be a true community of brothers where all respect and love one another.

Secular people are interested to find a community that helps them to find a solution to their familiar and personal problems. Some practical recommendations that can help communicators to approach secular people are presented.

\section{The Church as People of God}

The English word church comes from the Greek term 
kupıakós, "belonging to the Lord." In the old Testament the Hebrew word STק designates the assembly of God's people (Deut 10:4; 31:30). It is translated in the IXX, the Greek

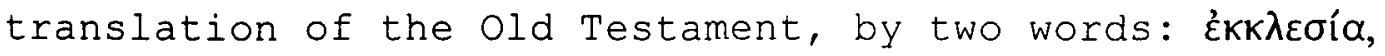
which means "a public assembly of God's people," and

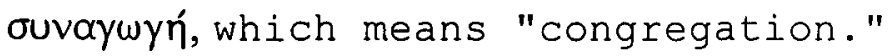

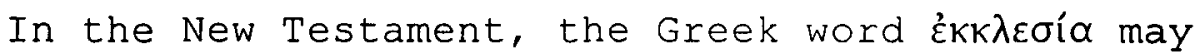
signify a public assembly (Acts 19:32, 39, 41) or the assembly of the Israelites (Acts 7:38; Heb 2:12). Usually it designates the Christian church, both local (Acts 15:41; Rom 16:16) and universal (Acts 20:28; 1 Cor 15:9).

There is a multiplicity of images and concepts in the New Testament that contributes to an understanding of the nature of the church. In the New Testament, especially in the writings of the Apostle Paul, the concept of the church as the body of Christ is found. "Christ is the head of the Church, his body, of which he is the Savior" (Eph 5:23). This concept was developed after the resurrection of Christ. He continues to be present in the world through His Church, which ought to reflect His character and imitate His manner of living. Christ, as the head, leads His Church. Christ is the only supreme leader. The Church as body cannot have two heads; in that case it would be a monster. Those who are sons of God belong to the body of Christ. They are brothers and among them there should be neither 
discrimination nor privileges.

You are all sons of God through faith in Christ Jesus,

for all of you who were baptized into christ have

clothed yourselves with Christ. There is neither Jew

nor Greek, slave nor free, male nor female, for you are all one in Christ Jesus. If you belong to Christ, then you are Abraham's seed, and heirs according to the promise. (Gal 3:26-29)

Fraternity is an important part of the message of Christ. Christianity calls the nations ( people of God ( $\delta$ גaós toũ $\theta \varepsilon$ oũ), in which the differences of race, culture, work, and sex cannot be reasons for privilege or discrimination. Fraternity is the fundamental element of each form of Christian association. When it is missing, the essence of Christianity is damaged. Love is a logical

consequence of the fraternity as the practice of Christian life. Love must be the guide in all relationships inside the community of believers as well as to those outside. The binomial friend-enemy does not make sense in the Christian message. The Christian community must be a house open to all persons, in which love, friendship, and esteem are the basic characteristics of the relationship between teacher and disciple, master and servant, rich and poor.

This is the kind of community that secular people can appreciate and to which they can desire to belong.

\section{The Ministry}

In the Middle Ages the Church separated its members 
into two classes: laity and clergy. But the term גaíkos is not in the Bible. Naíkos, in Hellenism, is the common, uncultivated human being, subservient to the authority of the cultivated and ruling class. Etymologically, the term

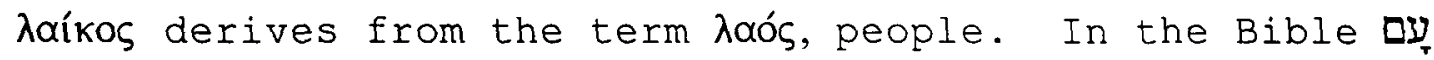

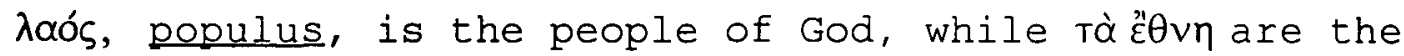
other nations.

In the Bible there are not two classes of persons: one sacred and the other profane. All members of God's people are sacred, called to exercise a universal priesthood. The life of Israel must be holy, subtracted from the profane.

The circumstances are known through which in the second and third centuries the priest-bishop office developed. The New Testament recognizes no difference between clergy and laity, between a 'spiritual' profession and a nonspiritual people of the Church. All are spiritual who are joined with Christ in faith through the Holy spirit. As such they are also all active, not only in daily living but in the worship service of the congregation. ${ }^{1}$

All Christians are "a royal priesthood, a holy nation,

a people belonging to God." (1 Pet 2:9).

But you are a chosen people, a royal priesthood, a holy nation, a people belonging to God, that you may declare the praises of him who called you out of darkness into his wonderful light (1 Pet 2:9).

Paul called the ministry of the gospel a "priestly duty

'Emil Brunner, The Divine-Human Encounter (Philadelphia: Westminster Press, 1943), 188. 
of proclaiming the gospel of God, so that the Gentiles might become an offering acceptable to God, sanctified by the Holy Spirit" (Rom 15:16). The members of God's people accomplish their priestly duty as "Christ's ambassadors." The Savior's commission to "go and make disciples of all nations" includes all believers in Christ.

In the Christian community there is a difference of gifts, which are received by members for the service to members to the community, as well as to those who are outside (1 Cor 12:4-13).

It is important that the church which will receive secular people ought to be a community in which the members participate to the activities of the community.

Christians must follow the example of Jesus, who "did not come to be served" (Matt 20:28). They must help and love each other. A church where the members love each other is certainly a strong magnet for secular people, who desire to find a community of true brothers.

According to secular people, institutionalized religion destroys the freedom of human beings, presenting and imposing its doctrimes in a dogmatic way without regard for human intelligence.

Freedom is a fundamental element of the church. Man must be free to understand, judge, and choose. Freedom is 
essential to growth. No man grows if he is not free--if he does not have the possibility of developing in an autonomous way. The institution that suppresses freedom damages the dignity of man.

\section{The Biblical View of Holistic Ministry}

Christians must imitate their "Lord Jesus Christ, that though he was rich, yet for your sakes he became poor, so that you through his poverty might become rich" (2 Cor 8:9). Jesus, the Messiah, was born "in a manger, because there was no room for them in the inn" (Luke 2:7). Jesus grew, was educated, and lived in a family of workers. People said: "Isn't this the carpenter?" (Mark 6:3). For about thirty years Jesus worked as a carpenter.

Jesus was not an ascetic; he was a part of a people who fought to preserve life and survived, thanks to their labor. That is why His language is full of images drawn from the world of workers and poor men.

Jesus established relationships with all classes of neglected people. It was His awareness of His Messianic mission and the establishment of the Kingdom of God that caused Jesus to approach poor men, the blind, lepers, tax collectors, foreigners, women, and all kind of people neglected in the society of His time.

Christ came to establish the kingdom of God.

He went to Nazareth, where he had been brought up, and on the sabbath day he went into the synagogue, as was 
his custom. And he stood up to read. The scroll of the prophet Isaiah was handed to him. Unrolling it, he found the place where it is written: "The spirit of the Lord is on me, because he has anointed me to preach good news to the poor. He has sent me to proclaim freedom for the prisoners and recovery of sight for the blind, to release the oppressed, to proclaim the year of the Lord's favor." Then he rolled up the scroll, gave it back to the attendant and sat down. The eyes of everyone in the synagogue were fastened on him, and he began by saying to them, "Today this scripture is fulfilled in your hearing". (Luke 4: 16-21)

Liberation from infirmity and oppression is a sign that follows the proclamation of the Kingdom of God. It is the justice of Messianic times, which cannot be nullified in a purely spiritual dimension, unless one wishes to destroy the deep realism characteristic of the scriptures and of the thought and action of Jesus Christ.

The reference to the year of Jubilee is a clear indication that Jesus proposed to the Christians a program of social justice. It is necessary to give a realistic interpretation of the announcement.

The Christian churches must be communities without any form of discrimination for race, sex, social position, etc. As sons of God, Christians must love God and their neighbors. Jesus identifies with the needy.

Then the King will say. . . 'Come, you who are blessed by my Father; take your inheritance, the kingdom prepared for you since the creation of the world. For I was hungry and you gave me something to eat, I was thirsty and you gave me something to drink, I was a stranger and you invited me in, I needed clothes and you clothed me, I was in prison and you came to visit me.' Then the righteous will answer him, 'Lord, when did we see you hungry and feed you?.. . The King will reply, 'I tell you the truth, whatever you did for one 
of the least of these brothers of mine, you did for me'. (Matt 25:34-46)

Christians help needy people, not because they hope to gain the right to enter the Kingdom of God, but because they are the sons of their Father in heaven, Who "causes his sun to rise on the evil and the good, and sends rain on the righteous and unrighteous" (Matt 5:44-48).

Christ became a servant to establish fraternal service as the central structure of the community (Matt 23:8-12).

The Christian community must be open to the poor, the crippled, the lame, the blind (Luke 14:12-14). The community of Christians must be a kolvwvía, in which every member shares "with God's people who are in need" and practices hospitality (Rom $12: 13$ ).

Christ's method alone will give true success in reaching the people. The savior mingled with men as one who desired their good. He showed His sympathy for them, ministered to their needs, and won their confidence. Then He bade them, "Follow Me." There is need of coming close to the people by personal effort. If less time were given to sermonizing, and more time were spent in personal ministry, greater results would be seen. The poor are to be relieved, the sick cared for, the sorrowing and the bereaved comforted, the ignorant instructed, the inexperienced counseled. We are to weep with those that weep, and rejoice with those that rejoice. Accompanied by the power of persuasion, the power of prayer, the power of the love of God, this work will not, cannot, be without fruits.

Secular people pay attention to the way a Christian community is living the message that it is proclaiming.

${ }^{1}$ Ellen G. White, The Ministry of Healing (Oshawa, Ontario, Canada: Pacific Press Publishing Association, 1942), 143, 144 . 
contradiction between the proclamation of the message and the life of biblical communicators is an obstacle to the credibility and acceptance of it. Secular people need a true, clear revelation of God and Christ in the life of biblical communicators.

The Christian community must accomplish all three of

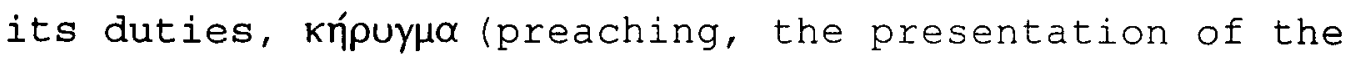
biblical message, Titus 1:3), kotvwvía (fellowship, Act

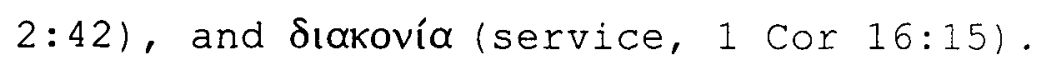

\section{The Biblical Message for a Whole Human Being}

The biblical covenant reconciles all creation to God and affects all aspects--physical, psychical, sociological, and spiritual--of human nature.

Western people are accustomed to separating the physical aspects of human nature from the spiritual. But the Bible considers a human being as a whole. There is no dualism between body and soul in the Bible. The human being is a whole being. According to the Bible, the human being does not have a body, a soul, and a spirit but is flesh, soul, and spirit. For the Apostle Paul, body, soul and spirit are manifestations of the whole human being ( 1 Thess $5: 23)$.

In presenting the biblical message it is necessary to consider all aspects of human nature: physical, psychological, social, and spiritual. The individual is to 
be saved as a whole person. The plan of salvation affects all aspects of human nature.

In His ministry Jesus taught, preached, and healed people (Matt 4:23). Christian messengers in their ministry should consider all aspects of human nature. They must help secular people to restore the complete nature. It is helpful to use the holistic health reform approach to appeal to the secular mind.

In the physical sphere many approaches are available to meet secular people: Five-day plans (to help people stop smoking), classes about health, stress, nutrition, and natural therapies, etc. As we have seen, ${ }^{1}$ secular people are "life oriented"; they are interested in real life before death.

Secular people generally are interested in finding solutions to their familial and social problems. Man was created as a social being. Among the people of Israel the individual was both family and community related.

The Bible teaches that "God created man in his own image, in the image of God he created him; male and female he created them" (Gen 1:27). Both man and woman were created in the image of God. The book of Genesis presents them as 'partners' even if they have the different characteristics of their sex.

\footnotetext{
${ }^{1}$ See p. 127 above.
} 
Both stories of the creation of man and woman (Gen 1 and 2) express a unique, essential truth: both man and woman were created by God with the same dignity and purpose. Adam and Eve were complete human persons. Genesis describes the idyliic first encounter between Adam and Eve. God led Eve to man, who exclaimed: "This is now bone of my bones and flesh of my flesh; she shall be called 'woman', for she was taken out of man" (Gen 2:23). This was the first love song. Later, sin spoiled their relationship. Passion and egotism mastered them.

In His warnings, full of mercy, God points out the tribulations that would strike sinful mankind. The man would dominate the woman. Often the woman would become an object of pleasure and would lose her personality. This situation is the consequence of sin and not the will of God. God only described the new situation caused by sin. Still, today sin is the cause of division and alienation. In our society many homes and families are divided.

The work of restoring an atmosphere of confidence and love in families is a mission of the christian Church. It is important to offer special seminars about home and family problems.

\section{Some Practical Recommendations}

\section{Informal meetings}


Many secular people want nothing to do with organized religion but they are interested to hear and examine problems related to religious faith. Sometimes it is possible to establish a friendship and, in informal meetings, to begin a dialogue.

\section{Unconscious spirituality}

The great mission of the Christian Church in secular society is to help people to understand their unconscious spirituality; to perceive the presence of God in their lives; to establish a constant and personal relationship with God.

\section{Secular young people still continue to believe in}

God

Many secular young people, despite their rejection of institutional religion, continue to believe in God. Many read books on Eastern religions, try to learn the art of transcendental meditation, and sing protest songs.

They can be attracted to participate in some social activities, in which the problems of our society can be debated.

4. Present the biblical message not in an authoritarian way

Secular people do not accept authoritarian preaching. The most useful approach is dialogue, which must be sincere and honest, in which everybody can participate.

5. The philosophical idea of God 
God, presented in a philosophical abstract way, the logical ens realissimum, appears to be unrelated to the world and to be little concerned with human life. He is the God at the end of an argument, not the God who is known in a faith encounter. What is important is to know God personally and to establish a direct relationship with Him.

6. Secular people do not like any pressure

Secular people do not like any pressure. They do not like to sign the guest book or give their personal data and address. They do not like to stand up during meetings or any form of religious or psychological pressure. Once some bonds of friendship are established, they prefer one-to-one or small meetings, among friends. They like communicators who take time to listen to their concerns with a genuine interest.

\section{The typical worship service is not attractive}

Many sermons are out-of-date, not related to the reality of our times. The content of these is often superficial or abstract. Often when the sermon is finished and people leave the chapel, nothing remains in their mind and their hearts. Many times the subject of the sermon is different from the subject of the songs and the special music. The purpose of the songs and music is to present a message. Nevertheless, the presentation of many songs does not communicate a message and they seem more cultural representations than a part of religious worship. 
8. The Sabbath School

It is important that Sabbath School must be more attractive. Many Sabbath School meetings are routine. It is necessary to change the order of the parts of sabbath School and to introduce something new. When the mission needs of the different parts of the world are presented, this is a good occasion to present recent statistics of that country of which they are speaking and show some of its problems. Sometimes the statistics presented are out-ofdate and nobody exposes the political, economical, and religious situation of the country.

Often, the lessons are prepared in a superficial way. There is little possibility of saying deep things in a clear and concrete way, and at times lessons give rise to more problems than solutions. The biblical message is presented at times in an incorrect, imprecise, vague way. Before giving the Sabbath school lesson to secular people it is necessary to examine the content, especially the first time secular people participate in the sabbath meetings.

The teachers of the classes must be prepared by specialists so that they can present the lesson in a competent and interesting way. Avoid asking if the members have studied or not. Secular people do not like to be submitted to pressures. If the subject of the lesson is examined with competence and is related to the problems of human life of our times, certainly every person will 
participate in the lessons.

9. Communicators

It is not easy to find persons who are able to present the biblical message to secular people. The discovery and recruitment of communicators require observation and knowledge of the real and potential abilities. It is very important that the communicators have a strong relationship with God.

They must have the ability to identify with secular people, to get close to them, to understand their problems, and to see the world through their eyes.

They must receive serious preparation about the process of secularization and the causes that have produced secularism.

They need deep biblical knowledge, because secular people ask very difficult questions and want direct and satisfactory answers. They must know how to present the message to secular people.

The instructors of communicators should have considerable theological, philosophical, and scientific preparation for the task.

It is better to choose professionals as communicators rather than pastors. The professionals can better understand the mind of other professionals, who generally feel more free to put questions to fellow professionals and do not have prejudice against them. Sometimes secular 
people have prejudices against clergy.

\section{$\underline{\text { Summary }}$}

The principal points of the biblical message have been considered in the last three chapters. It is important to present the content of the message in a clear, rational, and concrete way.

In presenting the biblical message, communicators must bear in mind the characteristics of the attitudes and thought forms of the secular people to whom they are presenting the message.

It is also necessary to prepare a community to receive secular people in a positive and affirming manner.

Communicators must remember that secular people need an ideal model toward whom they can orient their life. Only a community of true Christians, in whom Christ the ideal model of human life lives, can help secular people to establish a tight relationship with the God of the Bible through Christ and to find a real solution to their personal and family problems. 
CHAPTER XII

CONCLUSION

The purpose of this dissertation has been to: (1) describe the rise and development of the process of secularization; (2) construct a profile of secular people; (3) explore possible avenues of approach in presenting the biblical message; (4) and develop a strategy that allows biblical communicators to engage this group of people.

We have considered all these aspects of the subject of the dissertation in the two parts in which the dissertation has been divided.

In Part One we have seen how philosophical, theological and scientific trends and some political events like the Thirty Years' War have contributed to the formation and development of the process of secularization.

The historical part of the dissertation has clearly shown the weighty influence of secular philosophy on Western culture. Secular people are the natural products of this process and of Western education.

Secularization is a process by which our society has 
come to live more and more without religion. The profile of secular people presented in the dissertation has helped to give a better understanding of their mentality. God wants all people to listen to and understand the biblical message. However, it is very difficult to reach secular people because they have many prejudices toward any form of religion.

In Part Two we have seen that the message must be contextualized, that it must be presented in language and thought forms that secular people understand. Besides, two dangers must be avoided: the blending of the biblical message with Western culture, and the presentation of the Gospel in a superficial or abstract way. The message must be made comprehensible and relevant.

We have seen also that the three basic concepts of biblical message--God, Yahweh, the living God, who created the universe and inspired the writers of the Bible, the covenant though which God transforms people into His sons, and the church, as the people of God--must be presented in a rational and engaging manner.

Communicators must be chosen and prepared with care. They should have a deep understanding of the biblical message and ways of presenting it. They must consider the whole human being. The church should also be prepared to 
receive secular people with understanding.

We have seen that the biblical message must be presented in every place to every person. This includes secular intellectuals.

God is shaking the cultural barriers that once hindered the presentation of the biblical message. We must take advantage of this new situation and present the message aloud and without any fear. This task is not easy. We hope that this study can contribute toward the fulfilment of this objective. Finally, we must remember that this mandate will be achieved 'not by might nor by power, but by my Spirit' says the Lord Almighty (Zech $4: 6$ ). 
APPENDIX

\section{Ellen G. White statements}

For the benefit of SDA Church members some Ellen G. White statements are presented regarding the creation week.

\section{Other Worlds Already Existed before Creation week}

God's government included not only the inhabitants of heaven, but of all the worlds that He had created.'

Man was created a free moral agent. Like the inhabitants of other worlds, he must be subjected to the test of obedience. ${ }^{2}$

\section{The Rising and setting of the sun during All the Seven Days of the Creation Week}

The Bible record is in harmony with itself and with the teaching of nature. Of the first day employed in the work of creation is given the record, "The evening and morning were the first day." Genesis 1:5. And the same in substance is said of each of the first six days of creation week. Each of these periods Inspiration declares to have been a day consisting of evening and morning, like every other day since that time. ${ }^{3}$

God speaks to the human family in language they can comprehend. . . . When the Lord declares that He made the world in six days and rested on the seventh day, He means

${ }^{1}$ Ellen G. White, The Great Controversy (Mountain View, CA: Pacific Press Publishing Association, 1950), 497.

${ }^{2}$ Ellen G. White, The Story of Patriarchs and Prophets (Mountain View, CA: Pacific Press Publishing Association, $1958), 331,332$.

${ }^{3}$ Ellen G. White, Education (Oshawa, Ontario, Canada: Pacific Press Publishing Association, 1952), 129. 
the day of twenty-fours, which He has marked off by the rising and setting of the sun. ${ }^{1}$

${ }^{1}$ Ellen G. White, Testimonies to Ministers (Oshawa, Ontario, Canada: Pacific Publishing Association, 1962), 136. 
Adams, James R. So You Think You're Not Religious? Cambridge, MA: Cowley Publications, 1989.

Allen, Diogenes. Christian Belief in a Postmodern World. Louisville, KY: Westminster, John Knox Press, 1989.

Allen, Roland. Missionary Methods: St. Paul or Ours? London: World Dominion Press, 1930.

Anderson, Bernhard W. Creation versus Chaos. Philadelphia: Fortress Press, 1987.

Aristotle. The Complete Works of Aristotle. Edited by Jonathan Barnes. 2 vols. Princeton, NJ: Princeton University Press, 1984.

Atti del Convegno. "Teologia e Secolarizzazione." Teologia e Secolarizzazione. Napoli: Guida Editori, 1987.

Ayer, Alfred Jules. Language, Truth and Logic. London: Victor Gollancz, 1956.

Barbour, Ian G. Ethics in an Age of Technology. San Francisco: Harper Collins Publishers, 1993. - Religion in an Age of Science. San Francisco: Harper and Row, 1989.

Berdyaev, Nicolas. The Realm of spirit and the Realm of Caesar. Translated by Donald A. Lowrie. New York: Harper and Brothers, 1953.

Berger, Peter L. The Heretical Imperative. New York: Anchor Books, 1980.

- The Sacred Canopy. Garden City, NY: Doubleday \& Company, 1967.

Berger, Peter L., Brigitte Berger, and Hansfried Kellner. The Homeless Mind. New York: Random House, 1973. 
Best, Ernest. Paul and His Converts. Edinburg: T. \& T. Clark, 1988.

Beyer, Peter. Religion and Globalization. London: Sage Publications, 1994.

Bianchi, Eugene C. Reconciliation. The Function of the Church. New York: Sheed and Ward, 1969.

Black, Max. A Companion to Wittgenstein's 'Tractatus'. New York: Cornell University Press, 1966.

Blackwell, Richard J. Galileo, Bellarmine, and the Bible. Notre Dame, IN: University of Notre Dame Press, 1991.

Blamires, Harry. The Secularist Heresy. Ann Arbor, MI: Servant Books, 1980.

Bodley, John H. Cultural Anthropology. Mountain View, CA: Mayfield Publishing Company, 1994.

Boman, Thorleif. Hebrew Thought Compared with Greek. New York: W. W. Norton \& Company, 1960.

Bonhoeffer, Dietrich. The Cost of Discipleship. New York: A Touchstone Book, 1995. - Letters and Papers from Prison. Edited by E. Bethge. New York: Macmillan Company, 1967.

Bornkamm, Gunther. Pablo de Tarso. Salamanca: Ediciones Sigueme, 1982 .

Bozeman, Theodore Dwight. Protestants in an Age of Science. Chapel Hill, NC: The University of North Carolina Press, 1977.

Bradshaw, Bruce. Bridging the Gap. Monrovia, CA: Marc, 1984.

Brooke, John Hedley. Science and Religion: Some Historical Perspectives. Cambridge: Cambridge University Press, 1991.

Bruce, Steve. A House Divided: Protestantism, Schism, and Secularization. London and New York: Routledge, 1990.

Brunner, Emil. The Divine-Human Encounter. Philadelphia: Westminster Press, 1943. 
Buonfiglio, Michele. Ciencia o Dios? Nirgua, Venezuela: Editorial Universitaria Adventista, 1993.

- La libertà della volontà nel diritto penale. Jurisprudence Doctor diss., University of Naples, 1958.

Burhoe, Ralph Wendell, ed. Science and Human Values in the 21st Century. Philadelphia: Westminster Press, 1971.

Bush, L. Russ. A Handbook for Christian Philosophy. Grand Rapids, MI: Zondervan Publishing House, 1991.

Campanini, Giorgio, and Paolo Nepi. Cristianita'e Modernita'. Rome: Editrice A.V.E., 1992.

Chenu, M. D. Theologie de la Matiere. Paris: Les Editions du Cerf, 1968.

Childress, James F., and David B. Harned, eds. Secularization and the protestant prospect.

Philadelphia: Westminster Press, 1970.

Clinton, J. Robert. The Making of a Leader. Colorado Springs, CO: NavPress, 1993.

Coffin, Harold G. Creation-Accident or Design? Washington, DC: Review and Herald Publishing Association, 1969.

Cohen, Boaz. Jewish and Roman Law. 2 vols. New York: The Jewish Theological Seminary of America, 1966.

Copleston, Frederick. A History of Philosophy. 9 vols. New York: Bantam Doubleday Dell Publishing Group, 1985.

Cox, Harvey. The Secular City. New York: Macmillan Company, 1966.

Crease, Robert P., and Charles C. Mann. The Second Creation. New York: Macmillan Publishing Company, 1986.

Cullmann, Oscar. Christ and Time. Philadelphia: Westminster Press, 1950 .

Cunningham, Richard B. The Christian Eaith and Its Contemporary Rivals. Nashville, TN: Broadman Press, 1988 .

Cupitt, Don. The Sea of Faith. London: SMC Press, 1994. 
"Darkness Was upon the Face of the Deep." Seventh-day Adventist Bible Commentary. Edited by F. D. Nichol. Washington, DC: Review and Herald Pub. Assn., 1:209.

"Date of Creation Not Known." Seventh-day Adventist Bible Commentary. Edited by F. D. Nichol. Washington, DC: Review and Herald Pub. Assn., 1953-57. 1:195.

Davies, Paul. La Mente di Dio. Milano: Arnoldo Mondadori, 1993.

Davies, Paul. The Mind of God. New York: Simon \& Schuster, 1992.

Davis, Charles. Theology for Today. New York: Sheed and Ward, 1962.

Dean, Thomas. Post-Theistic Thinking. Philadelphia: Temple University Press, 1975.

Dillenberger, John. Protestant Thought and Natural Science. Notre Dame, IN: University of Notre Dame Press, 1988.

Documenta Missionalia: Evangelisation. Edited by M. Dhavamony. Rome: Universita' Gregoriana Editrice, 1975.

Durkheim, Emile. Durkheim on Religion. Edited by W. S. F. Pickering. Atlanta, GA: Scholars Press, 1994.

Ecumenical Studies in Theology: The Contemporary Explosion of Theology. Metuchen, NJ: Scarecrow Press, 1975.

Eddington, Arthur Stanley. Science and the Unseen World. New York: Macmillan Company, 1929.

Eichrodt, Walther. Theology of the Old Testament. 2 vols. Philadelphia: Westminster Press, 1961.

Eidelberg, Paul. Beyond the Secular Mind. New York: Greenwood Press, 1989.

Einstein, Albert. Ideas and Opinions. New York: Bonanza Books, 1954 .

Elliston, Edgar J. Home Grown Leaders. Pasadena, CA: William Carey Library, 1992. 
Elwell, Walter A. Evangelical Dictionary of Theology. Grand Rapids, MI: Baker Book House, 1984.

Evans, James. "Ptolemy." In Cosmology, edited by Norriss S. Hetherington. New York: Garland Publishing, 1993.

"The Evening and the Morning Were the First Day." Seventhday Adventist Bible Commentary. Edited by F. D. Nichol. Washington, DC: Review and Herald Pub. Assn., 1953-57. $1: 210$.

Ferrarotti, Franco. Faith Without Dogma: The Place of Religion in Postmodern Societies. New Brunswick, Canada: Transaction Publishers, 1993.

Feuerbach, Ludwig. The Essence of Christianity. Translated by George Eliot. New York: Harper \& Brothers, 1957.

- Lectures on the Essence of Religion. Translated by Ralph Manheim. New York: Harper \& Row, Publishers, 1967 .

Fizzotti, Eugenio. Lottare per l'Uomo. Napoli: Edizioni Dehoniane, 1981.

Ford, David. The Modern Theologians: An Introduction to Christian Theology in then Twentieth Century. New York: B. Blackwell, 1989 .

Freud, Sigmund. Totem and Taboo. Translated by James Strachey. New York: W. W. Norton \& Company, 1950.

Eromm, Erich. You Shall Be Gods. New York: Holt, Rinehart and Winston, 1966.

Fuller, B. A. G. A History of Philosophy. New York: Holt, Rinehart and Winston, 1960.

Gartner, Bertil. The Areopagus Speech and Natural

Revelation. Copenhagen: ALmquist \& Wiksells, 1955.

Gibbs, Eddie. In Name Only. Tunbridge Wells, Kent, England: A BridgePoint Book, 1994.

Gilardi, Enrico. La Scelta di Dio. Leumann, Torino: Elle Di Ci, 1977. 
Gilkey, Langdon. Religion and the Scientific Future. New York and London: Harper \& Row Publishers, 1970.

"God Called the Firmament Heaven." Seventh-day Adventist Bible Commentary. Edited by F. D. Nichol. Washington, DC: Review and Herald Pub. Assn., 1953-57. 1: 211.

Gogarten, Friedrich. Despair and Hope For Our Time. Philadelphia: Pilgrim Press, 1970.

Grenz, Stanley J., and Roger E. Olson. 20th Century Theology. Downers Grove, IL: InterVarsity Press, 1992.

Grounds, Vernon C. "Pacesetters for the Radical Theologians of the Sixties and Seventies." In Tensions in Contemporary Theology, ed. Stanley N. Gundry and Alan F. Jonson. Chicago: Moody Press, 1976.

Grunlan, Stephen A., and Marvin K. Mayers. Cultural Anthropology. Grand Rapids, MI: Academie Books, 1988.

Gundry, Stanley N., and Alan F. Johnson, eds. Tensions in Contemporary Theology. Chicago: Moody Press, 1976.

Harned, David Baily. The Ambiguity of Religion. Philadelphia: Westminster Press, 1968.

Hasel, Gerhard. old Testament Theology: Basic Issues in the Current Debate. Grand Rapids, MI: William B. Eerdmans Publishing Company, 1982.

Hauerwas, Stanley, and L. Gregory Jones, eds. Why Narrative? Readings in Narrative Theology. Grand Rapids, MI: William B. Eerdmans Publishing Company, 1989.

Heraclitus. Heraclitus, the Cosmic Fragments. Cambridge: The Cambridge University Press, 1962.

Hetherington, Norriss S., ed. Cosmology. New York: Garland Publishing, 1993.

Hiebert, Paul G. Anthropological Insights for Missionaries. Grand Rapids, MI: Baker Book House, 1985. - Cultural Anthropology. Philadelphia: J. B. Lippincott Company, 1976. 
- "The Flaw of the Excluded Middle." Missiology 10, no. 1 (January 1982): 43, 44 .

Hirschberger, Johannes. Breve Historia de la Filosofia

Barcelona: Editorial Herder, 1982.

- The History of Philosophy. 2 vols. Milwaukee:

Bruce Publishing Company, 1959.

Hoebel, E. Adamson. Anthropology: The Study of Man. New

York: McGraw-Hill Book Company, 1966.

Hunter, George G, III. The Contagious Congregation.

Nashvilie, TN: Abingdon Press, 1979.

- How to Reach Secular People. Nashville, TN:

Abingdon Press, 1992 .

"In the Beginning." Seventh-day Adventist Bible Commentary. Edited by F. D. Nichol. Washington, DC: Review and Herald Pub. Assn., 1953-57. 1:208.

Johnson, Kent L. Paul the Teacher. Minneapolis: Augsburg Publishing House, 1986.

Jones, W. T. The Twentieth century to Wittgenstein and

Sartre. San Diego: Harcourt Brace Jovanovich, 1975.

Kierkegaard, Soren Aabye. Kierkegaard, The Difficulty of

Being Christian. Edited by Jacques Colette. Notre Dame, IN: University of Notre Dame Press, 1968.

Kraft, Charles H. Christianity with Power. Ann Arbor, MI: Vine Books, 1989 .

- Christianity in Culture. Maryknoll, NY: Orbis Books, 1979 .

Krass, Alfred C. Evangelizing Neopagan North America. Scottdale, PA: Herald Press, 1982.

Kroeber, A. L., and Clyde Kluckhohn. Culture: A Critical Review of Concepts and Definitions. New York: Vintage Books, 1963.

Kuhn, Harold B. "Secular Theology." In Tensions in Contemporary Theology, ed. Stanley N. Gundry and Alan F. Johnson. Chicago: Moody Press, 1976. 
Kung, Hans. Christianity and World Religions. Maryknoll, NY: Orbis Books, 1993.

Lacroix, Jean. El Ateismo Moderno. Barcelona: Editorial Herder, 1968.

Lapide, Pinchas, and Peter Stuhlmacher. Paul, Rabbi and Apostle. Minneapolis: Augsburg Publishing House, 1984.

Latourelle, Rene. L'Uomo e i Suoi Problemi alla Luce di Cristo. Assisi, Italy: Citadella Editrice, 1982.

Liechty, Daniel. Theology in Postliberal Perspective. London: SCM Press, 1990.

Lipton, Peter. "Popper and Reliabilism." In Karl Popper: Philosophy and Problems, ed. by Anthony O'Hear. Cambridge: University Press, 1995.

Loen, Arnold E. Secularization Science Without God? Philadelphia: Westminster Press, 1967

Loffler, Paul, ed. Secular Man and Christian Mission. New York: Friendship Press, 1968.

Lonning, Per. Creation: An Ecumenical Challenge? Macon, GA: Mercer University Press, 1989.

Losee, John. A Historical Introduction to the Philosophy of Science. London: Oxford University Press, 1972.

Lynch, William F. Christ and Prometheus: A New Image of the Secular. Notre Dame, IN: University of Notre Dame Press, 1970.

Lyotard, Jean-François. The Postmodern Condition: A Report on Knowledge. Minneapolis: University of Minnesota, 1993.

Maffei, Paolo. L'Universo nel Tempo. Milano: Arnoldo Mondadori Editore, 1982 .

Martin, David. The Breaking of the Image. New York: St. Martin's Press, 1980.

Marx, Karl, and Friedrich Engels. On Religion. Chico, CA: Scholars Press, 1982 . 
Mayers, Marvin K. Christianity Confronts Culture. Grand Rapids, MI: Academie Books, Zondervan Publishing House, 1987.

McGrath, Alister E. Intellectuals Don't Need God. Grand Rapids, MI: Zondervan Publishing House, 1993.

McGravan, Donald A. Understanding Church Growth. Grand Rapids, MI: William B. Eerdmans Publishing Company, 1991.

McInerny, Ralph M. A History of Western Philosophy. Notre Dame, IN: University of Notre Dame Press, 1963.

Mol, Hans, ed. Western Religion. The Hague, Netherlands: Mouton \& Co., 1972.

Monod, Jacques. Chance and Necessity. New York: Alfred A. Knopf, 1971.

Montgomery, John Warwick, ed. Evidence for Eaith. Dallas: Probe Books, 1991.

More, Thomas Centre, ed. Christianisme et Modernite'. Maubourg, Paris: Les Editions du Cerf, 1990.

Morrison, Roy D., II. Science, Theology and the Transcendental Horizon. Atlanta, GA: Scholars Press, 1994 .

Mueller, Juan Teodoro. Doctrina Cristiana. Saint Louis, MO: Casa Publicadora Concordia, 1948.

Murray, Donal. Secularism and the New Europe. Dublin: Veritas Publications, 1990.

Newbigin, Lesslie. Eoolishness to the Greeks. Grand Rapids, MI: William B. Eerdmans Publishing Company, 1986.

- The Good Shepherd. Grand Rapids, MI: William B. Eerdmans Publishing Company, 1977.

- The Gospel in a Pluralist Society. Grand Rapids, MI: William B. Eerdmans, 1989.

- The Open Secret. Grand Rapids, MI: William B. Eerdmans, 1995. 
Nicholls, Bruce J. Contextualization: A Theology of Gospel and Culture. Downers Grove, IL: Intervarsity Press, 1979 .

Nicholson, Ernest W. God and His People. Oxford: Clarendon Press, 1986.

Niebuhr, H. Richard. Christ and Culture. New York: Harper \& Brothers, 1951 .

Nietzsche, Friedrich. Ecce Homo. Middlesex, England: Penguin Books, 1979 .

O'Dea, Thomas F. Sociologia della Religione. Bologna: Società Editrice Il Mulino, 1971.

O'Dea, Thomas F., and Janet O'Dea Aviad. The Sociology of Religion. Englewood Cliffs, NJ: Prentice-Hall, 1983.

Oden, Thomas C. After Modernity... What?: Agenda for Theology. Grand Rapids, MI: Zondervan Publishing House, 1992 .

O'Hear, Anthony. Karl Popper: Philosophy and Problems. Cambridge: University Press, 1995.

Oosterwal, Gottfried. "The People of God." In God's Chosen People, Adult Sabbath School Lessons. Mountain View, CA: Pacific Press Publishing Association, 1977.

Pacini, David S. The Cunning of Modern Religious Thought. Philadelphia: Fortress Press, 1987.

Pannenberg, Wolfhart. Antropologia en Perspectiva Teologica. Salamanca: Ediciones Sigueme, 1993.

- Christianity in a Secularized World. New York: Crossroad, 1989.

- Systematic Theology. Grand Rapids, MI: William B. Eerdmans, 1991.

- Theology and the Philosophy of Science.

Philadelphia: Westminster Press, 1976. 
Paulien, Jon. Present Truth in the Real World. Oshawa, Ontario, Canada: Pacific Press Publishing Association, 1993.

Pickering, W. S. E. Durkheim's Sociology of Religion. London: Poutledge \& Kegan Paul, 1984.

Planck, M. La conoscenza del mondo scientifico. Torino: Boringhieri, 1943

- Where Is Science Going? Woodbridge, CT: Ox Bow Press, 1981 .

Puech, Henri-Charles. Historia de las Religiones. 6 vols. Mexico, DF: Siglo Veintuno Editores, 1970.

Rasi, Humberto M., and Fritz Guy, eds. Meeting the Secular Mind: Some Adventist Perspectives. Berrien Springs, MI: Andrews University Press, 1985.

Reichenbach, Hans. The Rise of Scientific Philosophy.

Berkeley: University of California Press, 1959.

Review and Herald Publishing Association. Our Firm Foundation. Washington, DC: Review and Herald Publishing Association, 1953.

Ricca, Paolo. La Morte di Dio: una Nuova Teologia? Torino: Editrice Claudiana, 1967.

Richard, Robert L. Secularization Theology. New York: Herder and Herder, 1967.

Richardson, Alan, and John Bowden, eds. A New Dictionary of Christian Theology. London: SCM Press, 1989.

Robinson, John A. T. Honest to God. Philadelphia: Westminster Press, 1963.

- The New Reformation? Philadelphia: Westminster Press, 1965 .

Robertson, O. Palmer. The Christ of the Covenants. Grand Rapids, MI: Baker Book House, 1980.

Russell, Bertrand. Bertrand Russell on God and Religion. Buffalo, NY: Prometheus Books, 1986. 
- What I Believe. London: Kegan Paul, Trench, Trubner \& Co., 1930 .

Ryan, Michael D. The Contemporary Explosion of Theology. Metuchen, NJ: Scarecrow Press, 1975.

Sambursky, Shmuel, ed. Physical Thought. New York: Pica Press, 1975.

Sartre, Jean-Paul. Existentialism and Humanism. Translated by Philip Mairet. London: Methuen \& Co., 1965.

Sarup, Madan. An Introductory Guide to Post-Structuralism and Postmodernism. Athens: The University of Georgia Press, 1993.

Schillebeeckx, E. God and Man. New York: Sheed and Ward, 1969. 1968 .

- God the Future of Man. New York: Sheed and Ward,

Schlitzer, Albert. The spirit and Power of Christian Secularity. Notre Dame, IN: University of Notre Dame Press, 1969.

Sermonti, Giuseppe, and Roberto Fondi. Dopo Darwin. Milano: Rusconi, 1982 .

Seventh-day Adventist Encyclopedia. S. v. "Creation" 1:417. Hagerstown, MD: Review and Herald, 1996.

Seventh-day Adventist Bible Commentary. Edited by F. D. Nichol. Washington, DC: Review and Herald, 1976. 1:195, $208,209,210,213$.

Shorter, Aylward. Toward a Theology of Inculturation. Maryknoll, NY: Orbis Books, 1988.

Sironneau, Jean-Pierre. Secularisation et Religions Politiques. La Haye: Mouton Editeur, 1982.

Smith, David L. A Handbook of Contemporary Theologies. Wheaton, IL: A BridgePoint Book, 1992.

Smith, Donald K. Creating Understanding. Grand Rapids, MI: Zondervan Publishing House, 1992. 
Smith, Ralph I. Old Testament Theology. Nashville: Broadman \& Holman Publishers, 1993.

Soards, Marion L. The Apostle Paul. New York: Paulist Press, 1987.

Soloveitchik, Joseph. Halakhic Man. Philadelphia: Jewish Publication Society, 1983.

Stenius, Erik. Wittgenstein's Tractatus. Oxford: Basil Blackwell, 1964.

Tarnas, Richard. The Passion of the Western Mind. New York: Ballantine Books, 1993.

Tavard, Georges. La theologie parmi les sciences humaines. Paris: Editions Beauchesne, 1975.

Taylor, Gordon R. The Science of Life. New York: McGraw, Hill Book Company, 1963

Theissen, Gerd. Biblical Faith: An Evolutionary Approach. Philadelphia: Fortress Press, 1985.

Theological Dictionary of the New Testament. Edited by Kittel, Gerhard. Grand Rapids, MI: W.B. Eerdmans, 1964.

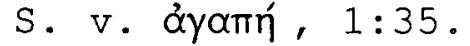

Theological Dictionary of the old Testament. Edited by Botterweck Johannes G., and Helmer Ringgren. Grand Rapids, MI: William B. Eerdmans, 1975. S.v. "'ahabh," "bara'."

The Signs of Times. Oakland, CA: the International Tract and Missionary Society, September 29, 1887, number 38 .

Thils, Gustave. Christianisme Sans Religion? Tournai, Belgique: Casterman, 1968.

- A Non-Religious Christianity? Staten Island, NY: Alba House, 1970.

Tillich, Paul. Systematic Theology. 3 vols Chicago: The University of Chicago Press, 1951-63.

Verhalen, Philip A. Faith in a Secularized World. New York: Paulist Press, 1953. 
von Rad, Gerhard. Estudios sobre el Antiguo Testamento. Salamanca: Ediciones Sigueme, 1982.

- old Testament Theology. 2 vols. New York: Harper \& Brothers Publishers, 1962.

Wardle, Terry. One to One. Camp Hill, PA: Christian Publications, 1989.

Weber, Alfred. Historia de la Cultura. Mexico, DF: Fondo de Cultura Economica, 1960.

Webster, Clyde L., Jr. The Earth. Washington, DC: North American Division, General Conference of Seventh-Day Adventists, 1989.

Weiss, Herold. Paul of Tarsus. Berrien Springs, MI: Andrews University Press, 1986.

White, Ellen G. The Acts of the Apostles. Boise, ID: Pacific Press Publishing Association, 1989.

- Fundamentals of Christian Education. Nashville, TN: Southern Publishing Association, 1923.

- The Great Controversy between Christ and Satan. Oshawa, Ontario, Canada: Pacific Press Publishing Association, 1950.

- The Ministry of Healing. Oshawa, Ontario, Canada: Pacific Press Publishing Association, 1942

- Selected Messages. 3 vols. Hagerstown, MD: Review and Herald Publishing Association, 1986.

- Spiritual Gifts. 4 vols. Washington DC: Review and Herald Publishing Association, 1945.

- The Story of Patriarchs and Prophets. Mountain View, CA: Pacific Publishing Association, 1958.

White, Ellen G., and James White. Christian Temperance and Bible Hygiene. Battle Creek, MI: Good Health Publishing Company, 1980 .

Witten, Marsha G. All Is Eorgiven: The Secular Message in American Protestantism. Princeton, NJ: Princeton University Press, 1993. 
Wolf, Hans Walter. Anthropology of the Old Testament. London: SMC Press, 1974..

Wuthnow, Robert. Christianity in the Twenty-first Century. Oxford: Oxford University Press, 1993.

Xhaufflaire, Marcel. Feuerbach et la Theologie de la Secularisation. Maubourg, Paris: Les Editions du Cerf, 1970 . 